\title{
Interventions for drug-using offenders with co-occurring mental illness (Review)
}

Perry AE, Neilson M, Martyn-St James M, Glanville JM, Woodhouse R, Godfrey C, Hewitt C

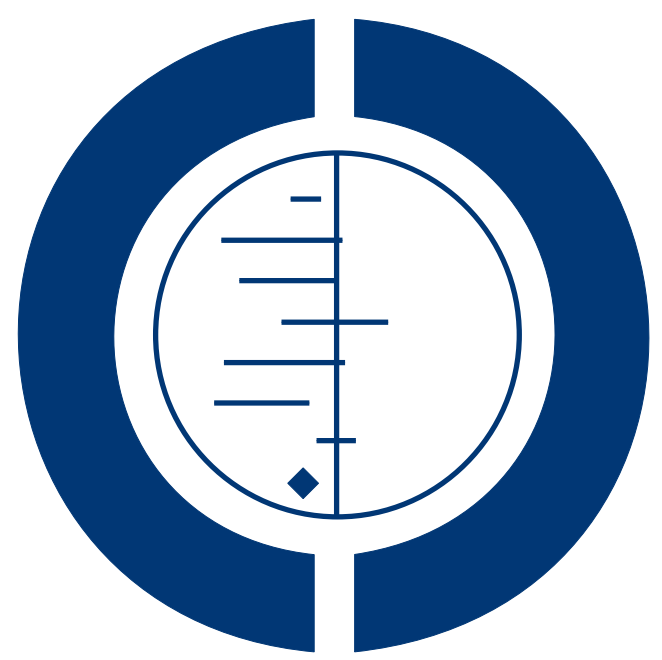

\section{THE COCHRANE COLLABORATION $^{\circledR}$}

This is a reprint of a Cochrane review, prepared and maintained by The Cochrane Collaboration and published in The Cochrane Library 2015, Issue 6

http://www.thecochranelibrary.com

\section{WILEY}

Interventions for drug-using offenders with co-occurring mental illness (Review)

Copyright $\odot 2015$ The Cochrane Collaboration. Published by John Wiley \& Sons, Ltd. 
TABLE OF CONTENTS

HEADER . . . . . . . . . . . . . . . . . . . . . . . . . . . . . . . . . . 1

ABSTRACT . . . . . . . . . . . . . . . . . . . . . . . . . . . . . . . . . . . . . . . 1

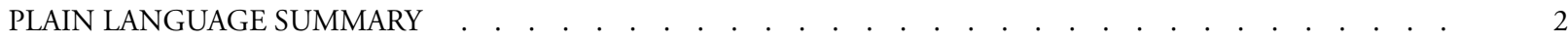

SUMMARY OF FINDINGS FOR THE MAIN COMPARISON $\quad$. . . . . . . . . . . . . . . . . . . . . . . . . .

BACKGROUND . . . . . . . . . . . . . . . . . . . . . . . . . . . . . . . . . . . . 5

OBJECTIVES . . . . . . . . . . . . . . . . . . . . . . . . . . . . . . . . . . . . . . . . . . . .

METHODS . . . . . . . . . . . . . . . . . . . . . . . . . . . . . . . . . . . . . . 6

RESUlTS . . . . . . . . . . . . . . . . . . . . . . . . . . . . . . . . . . . . . 9

Figure 1. . . . . . . . . . . . . . . . . . . . . . . . . . . . . . . . . . . . . 10

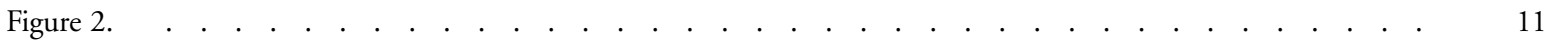

Figure 3. . . . . . . . . . . . . . . . . . . . . . . . . . . . . . . . . . . . . . 12

Figure $4 . \quad$. . . . . . . . . . . . . . . . . . . . . . . . . . . . . . . . . . . . . 14

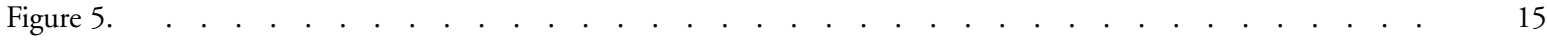

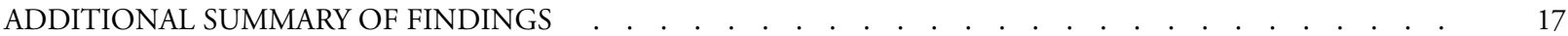

DISCUSSION . . . . . . . . . . . . . . . . . . . . . . . . . . . . . . . . . . . . . 22

AUTHORS' CONCLUSIONS . . . . . . . . . . . . . . . . . . . . . . . . . . . . . . . . . 24

ACKNOWLEDGEMENTS . . . . . . . . . . . . . . . . . . . . . . . . . . . . . . . . . . . . . . .

REFERENCES . . . . . . . . . . . . . . . . . . . . . . . . . . . . . . . . . . . . . . . . . . . 25

CHARACTERISTICS OF STUDIES . . . . . . . . . . . . . . . . . . . . . . . . . . . . . . . . . . . . . . .

DATA AND ANALYSES . . . . . . . . . . . . . . . . . . . . . . . . . . . . . . . . . . . . . . . . . . . . . . . .

Analysis 1.1. Comparison 1 Therapeutic community, Outcome 1 Criminal activity. . . . . . . . . . . . . . . . 62

Analysis 2.1. Comparison 2 Mental health court, Outcome 1 Self report dichotomous criminal activity. . . . . . 62

Analysis 3.1. Comparison 3 Motivational interviewing and cognitive skills, Outcome 1 Self report drug use continuous. 63

Analysis 3.2. Comparison 3 Motivational interviewing and cognitive skills, Outcome 2 Self report drug use dichotomous. 63

Analysis 4.1. Comparison 4 Interpersonal psychotherapy, Outcome 1 Self report drug use dichotomous. . . . . . 64

ADDITIONAL TABLES . . . . . . . . . . . . . . . . . . . . . . . . . . . . . . . . . . . . . . . . . . . . . . 64

APPENDICES . . . . . . . . . . . . . . . . . . . . . . . . . . . . . . . . . . . . . . . . . 67

WHAT'S NEW . . . . . . . . . . . . . . . . . . . . . . . . . . . . . . . . . . . . . . 97

HISTORY . . . . . . . . . . . . . . . . . . . . . . . . . . . . . . . . . . . . . . . . . . . . 97

CONTRIBUTIONS OF AUTHORS . . . . . . . . . . . . . . . . . . . . . . . . . . . . . . . . . . . . . . . . 98

DECLARATIONS OF INTEREST . . . . . . . . . . . . . . . . . . . . . . . . . . . . . . . . . . . . . . .

SOURCES OF SUPPORT . . . . . . . . . . . . . . . . . . . . . . . . . . . . . . . . . . . . . . . . . . . . . . . . . . .

DIFFERENCES BETWEEN PROTOCOL AND REVIEW . . . . . . . . . . . . . . . . . . . . . . . . . . . . 99

INDEX TERMS . . . . . . . . . . . . . . . . . . . . . . . . . . . . . . . . . . . . . . . 99

Interventions for drug-using offenders with co-occurring mental illness (Review)

Copyright () 2015 The Cochrane Collaboration. Published by John Wiley \& Sons, Ltd. 


\title{
[Intervention Review] \\ Interventions for drug-using offenders with co-occurring mental illness
}

\author{
Amanda E Perry ${ }^{1}$, Matthew Neilson ${ }^{1}$, Marrissa Martyn-St James ${ }^{2}$, Julie M Glanville ${ }^{3}$, Rebecca Woodhouse ${ }^{1}$, Christine Godfrey ${ }^{1}$, \\ Catherine Hewitt ${ }^{1}$ \\ ${ }^{1}$ Department of Health Sciences, University of York, York, UK. ${ }^{2}$ School of Health and Related Research (ScHARR), University of \\ Sheffield, Sheffield, UK. ${ }^{3}$ York Health Economics Consortium, York, UK \\ Contact address: Amanda E Perry, Department of Health Sciences, University of York, Heslington, York, YO105DD, UK. \\ amanda.perry@york.ac.uk.
}

Editorial group: Cochrane Drugs and Alcohol Group.

Publication status and date: New search for studies and content updated (no change to conclusions), published in Issue 6, 2015.

Review content assessed as up-to-date: 31 May 2014.

Citation: Perry AE, Neilson M, Martyn-St James M, Glanville JM, Woodhouse R, Godfrey C, Hewitt C. Interventions for drugusing offenders with co-occurring mental illness. Cochrane Database of Systematic Reviews 2015, Issue 6. Art. No.: CD010901. DOI: 10.1002/14651858.CD010901.pub2.

Copyright (C) 2015 The Cochrane Collaboration. Published by John Wiley \& Sons, Ltd.

\begin{abstract}
A B S T R A C T
Background

This is an updated version of an original Cochrane review published in Issue 32006 (Perry 2006). The review represents one from a family of four reviews focusing on interventions for drug-using offenders. This specific review considers interventions aimed at reducing drug use or criminal activity, or both for drug-using offenders with co-occurring mental illness.
\end{abstract}

\section{Objectives}

To assess the effectiveness of interventions for drug-using offenders with co-occurring mental illness in reducing criminal activity or drug use, or both.

\section{Search methods}

We searched 14 electronic bibliographic databases up to May 2014 and 5 Internet resources (searched between 2004 and 11 November 2009). We contacted experts in the field for further information.

\section{Selection criteria}

We included randomised controlled trials designed to reduce, eliminate, or prevent relapse of drug use and criminal activity, or both in drug-using offenders with co-occurring mental illness. We also reported data on the cost and cost-effectiveness of interventions.

\section{Data collection and analysis}

We used standard methodological procedures expected by The Cochrane Collaboration.

\section{Main results}

Eight trials with 2058 participants met the inclusion criteria. The methodological quality of the trials was generally difficult to rate due to a lack of clear reporting. On most 'Risk of bias' items, we rated the majority of studies as unclear. Overall, we could not statistically combine the results due to the heterogenous nature of the different study interventions and comparison groups. A narrative summary of the findings identified that the interventions reported limited success with reducing self report drug use, but did have some impact on

Interventions for drug-using offenders with co-occurring mental illness (Review)

Copyright $\odot 2015$ The Cochrane Collaboration. Published by John Wiley \& Sons, Ltd. 
re-incarceration rates, but not re-arrest. In the single comparisons, we found moderate-quality evidence that therapeutic communities determine a reduction in re-incarceration but reported less success for outcomes of re-arrest, moderate quality of evidence and self report drug use. Three single studies evaluating case management via a mental health drug court (very low quality of evidence), motivational interviewing and cognitive skills (low and very low quality of evidence) and interpersonal psychotherapy (very low quality of evidence) did not report significant reductions in criminal activity and self report drug use respectively. Quality of evidence for these three types of interventions was low to very low. The trials reported some cost information, but it was not sufficient to be able to evaluate the costeffectiveness of the interventions.

\section{Authors' conclusions}

Two of the five trials showed some promising results for the use of therapeutic communities and aftercare, but only in relation to reducing subsequent re-incarceration. Overall, the studies showed a high degree of variation, warranting a degree of caution in the interpretation of the magnitude of effect and direction of benefit for treatment outcomes. More evaluations are required to assess the effectiveness of interventions for drug-using offenders with co-occurring mental health problems.

\section{PLAIN LANGUAGESUMMARY}

\section{Interventions for drug-using offenders with co-occurring mental illness}

\section{Background}

A number of policy directives are aimed at enabling people with drug problems to live healthy, crime-free lives. Drug-using offenders with co-occurring mental health problems represent a group who access treatment for a variety of different reasons. The complexity of the two problems makes the treatment and rehabilitation of this group particularly challenging.

\section{Study characteristics}

The review authors searched scientific databases and Internet resources to identify randomised controlled trials (where participants are allocated at random to one of two or more treatment groups) of interventions to reduce, eliminate, or prevent relapse or criminal activity of drug-using offenders with co-occurring mental illness. We included people of any gender, age, or ethnicity.

\section{Key results}

We identified eight trials evaluating treatments for drug-using offenders with co-occurring mental illness. The interventions included case management via a mental health court: a therapeutic community; an evaluation of motivational interviewing techniques and cognitive skills (a person's ability to process thoughts) in comparison to relaxation training; and an evaluation of interpersonal psychotherapy in comparison to a psycho-educational intervention. Overall, the interventions reported limited success with reducing self report drug use, but did report some success with reducing re-incarceration rates, but not re-arrest. The therapeutic community studies reported a reduction in re-incarceration but were shown to be less effective for re-arrest and self report drug use. Three single studies evaluating case management via a mental health drug court, motivational interviewing and cognitive skills, and interpersonal psychotherapy did not report significant reductions in criminal activity and self report drug use respectively. Some information is provided on the costs and cost-effectiveness of such interventions and trial evaluations focusing specifically on the needs of drug-using offenders with cooccurring mental illness are required.

\section{Quality of the evidence}

This review was limited by the lack of information reported in this group of trials. The quality of the evidence was moderate for therapeutic community and low to very low for the other types of intervention. The evidence is current to May 2014. 


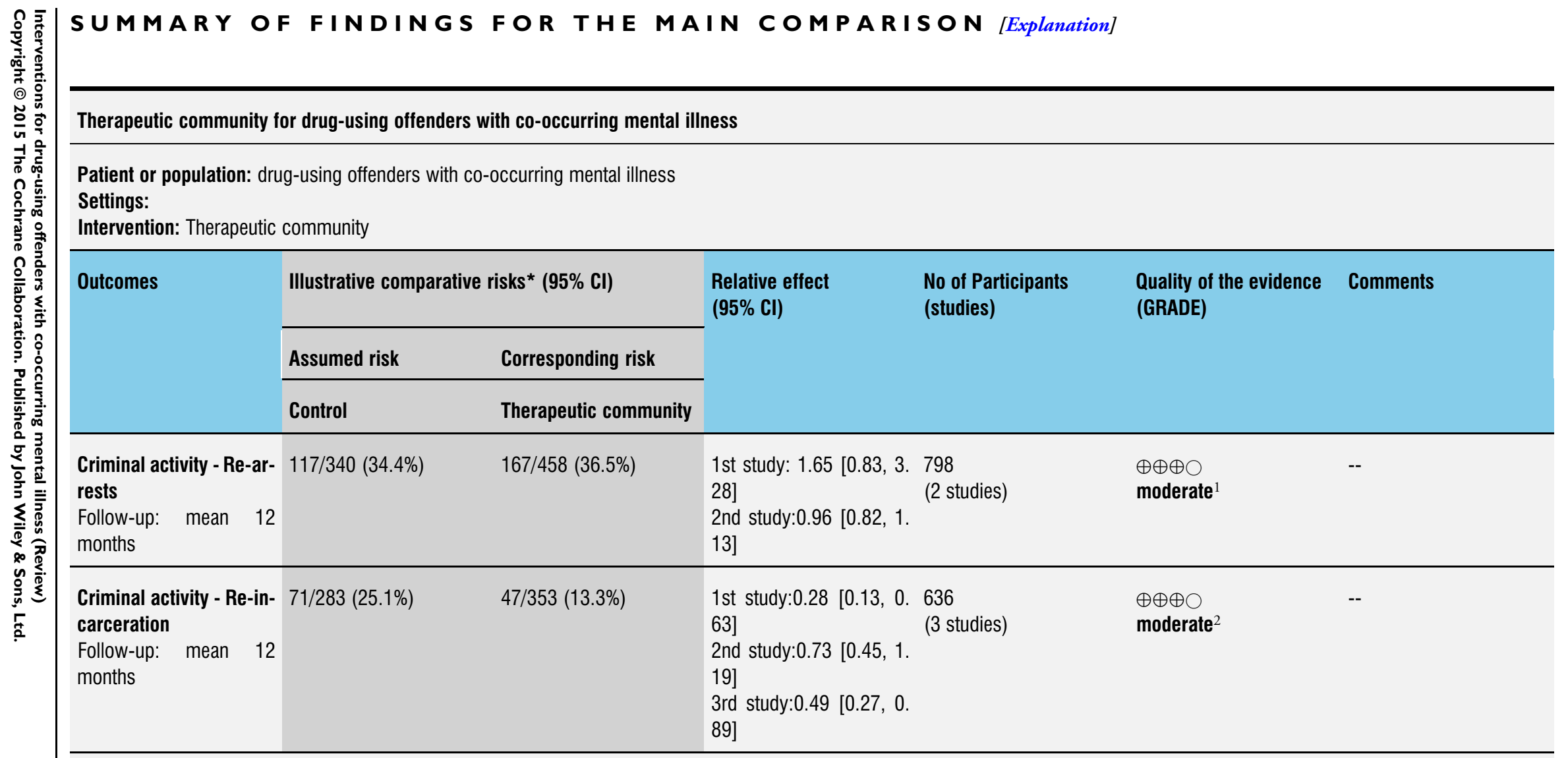

*The basis for the assumed risk (e.g. the median control group risk across studies) is provided in footnotes. The corresponding risk (and its $95 \%$ confidence interval) is based on the assumed risk in the comparison group and the relative effect of the intervention (and its $95 \% \mathrm{Cl}$ ).

Cl: confidence interval

GRADE Working Group grades of evidence

High quality: Further research is very unlikely to change our confidence in the estimate of effect.

Moderate quality: Further research is likely to have an important impact on our confidence in the estimate of effect and may change the estimate.

Low quality: Further research is very likely to have an important impact on our confidence in the estimate of effect and is likely to change the estimate.

Very low quality: We are very uncertain about the estimate.

${ }^{1}$ Across the 2 studies, 13 of the 18 'Risk of bias' items in total were rated as unclear risk; 2 of the 18 were rated as high risk. 


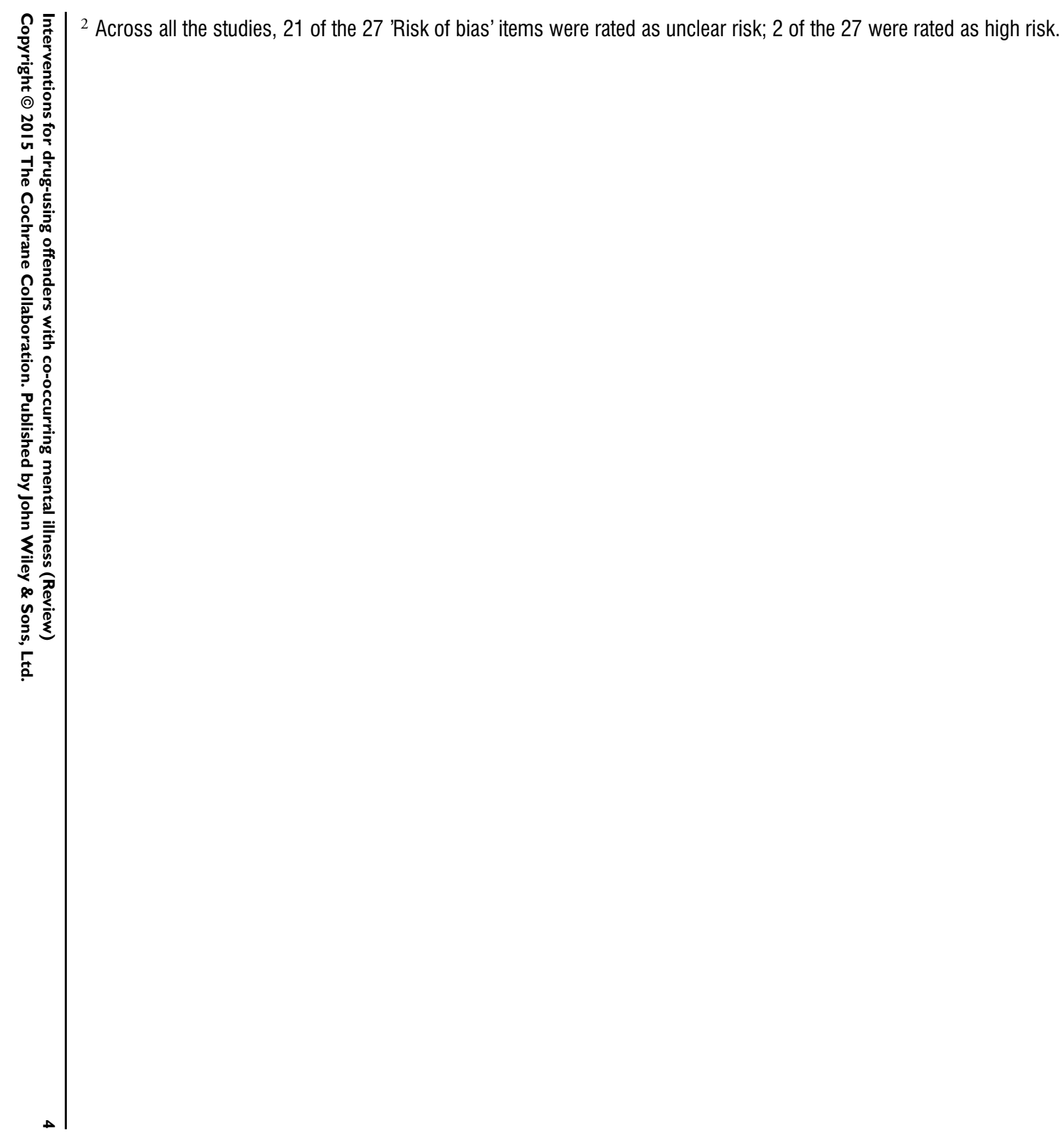




\section{B A C K G R O U N D}

This review is part of a family of four reviews providing a close examination of what works in reducing drug use and criminal activity in drug-using offenders. Overall, the four reviews contain over 100 trials, generating a number of publications and numerous comparisons (Perry 2013a; Perry 2013b; Perry 2013c). The four reviews represent a specific interest in pharmacological interventions, non-pharmacological interventions, female offenders, and offenders with co-occurring mental illness. All four reviews stem from an updated previous Cochrane systematic review (Perry 2006). In this set of four reviews, we consider not only the effectiveness of interventions based on two key outcomes but also analyse the impact of setting and intervention type. We have presented here the revised methodology for this individual review focusing on the impact of interventions for drug-using offenders with cooccurring mental illness.

\section{Description of the condition}

Mental health issues in offenders are common, with over half (64\%) of jail inmates in the US reporting a serious mental illness (Glase 2006). In the US, individuals incarcerated to jails are generally on remand awaiting trial, while those in prison have been sentenced within the criminal justice system. One study of mental illness in jails found that more women than men $(31 \%$ and $14.5 \%$, respectively) have a serious mental illness (Steadman 2009). Other studies have reported that a greater proportion of mentally ill people are arrested compared with the general population (Lamb 1998). Factors cited as causes include a lack of support in the community, problems accessing treatment, and the attitudes of police and society. A systematic review evaluating 62 surveys from 12 countries accounting for 23,000 prisoners. They found that prisoners were several times more likely to have psychosis or major depression and 10 times more likely to have an antisocial personality disorder than the general population. It is unknown how well the prison service is addressing these problems (Fazel 2002).

In the UK, renewed emphasis from Clarke's green paper, Breaking the Cycle, recognises that the justice system is not always the best place to manage the problems of less serious offenders, where their criminal behaviour is related to their mental health problems (Clarke 2010). As a result, several diversionary schemes have been established (Ministry of Justice 2010). The use of diversionary schemes have been supported by previous systematic reviews and meta-analytical techniques that have evaluated diversion programmes (for example mental health courts) providing a mechanism for diverting individuals with severe mental illness into treatment programmes instead of the prison system (Sarteschi 2011). Findings from such studies generally show positive improvements on a small number of clinical outcomes. However, the conclusions are often limited by the research design (that is quasi-experimental studies), introducing potential bias about the relative effectiveness of such schemes. Evidence from one systematic review of serious mentally disordered adult offenders identified seven trials, but the evidence was insufficient to draw conclusions. The authors called for more comparative trials to increase their confidence in the findings (Fontanarosa 2013).

\section{Description of the intervention}

Many different treatments for substance misuse (for example detoxification and therapeutic communities) have been adopted for use in the criminal justice system. This review included any intervention that was designed to reduce, eliminate, or prevent relapse to drug use or criminal activity, or both. This resulted in the inclusion of a wide range of treatments focusing on: case management via a mental health drug court, therapeutic communities, and motivational interviewing (MI) with cognitive skills in comparison to relaxation training. The evidence to support the effectiveness of these interventions differs and is dependent upon the quality of the experimental evaluations employed to assess whether they are successful in reducing drug use or criminal activity, or both.

Case management evolved traditionally to address the needs of prisoner re-entry programmes covering employment, education, health, housing, and family support via assessment and connecting clients with the appropriate services (Austin 1994). Case management in the US has been applied in Treatment Accountability for Safer Communities programmes (Marlowe 2003b), and has shown initial effectiveness but without systematic evidence in support of the process.

Previous meta-analyses and systematic reviews have shown therapeutic community interventions specifically with aftercare to have modest effects in the reduction of recidivism and drug use (Mitchell 2012a; Pearson 1999).

Cognitive behavioural approaches, including self monitoring, goal setting, self control training, interpersonal skills training, relapse prevention, group work, and lifestyle modification, have shown signs of success with offenders generally (Lipsey 2007), but the evidence is based on systematic reviews that have excluded evaluations focusing specifically on the needs of drug-using offenders. Two previous systematic reviews found that motivational interviewing can lead to improved retention in treatment, enhanced motivation to change, and reduced offending, although there are variations across studies (McMurran 2009; Smedslund 2011).

Interpersonal psychotherapy has been used in the community with proven effectiveness in non-criminal justice settings. Such studies have not found interpersonal psychotherapy to be superior to other treatments (Johnson 2012).

Policy interests have also placed an increasing demand on knowing more about the cost and cost-effectiveness of such interventions. We can draw some evidence from systematic reviews completed in the area. However, despite growing knowledge about the 
effectiveness of treatment programmes for offenders, there is no recent systematic review evidence focusing on the effectiveness of treatment for offenders with drug misuse and co-occurring mental health problems.

\section{How the intervention might work}

Interventions delivered to drug-using offenders under the care of the criminal justice system have varied over time. Case management is a problematic term that has been used to describe what amounts to a range of diverse practices and supervision models spanning several different services, including probation. These are generally used to co-ordinate and integrate all aspects of community supervision, from the initial offender needs assessment, through to programme delivery and the intended completion of the order or sentencing requirement (Partridge 2004).

In the US since the 1960s therapeutic community interventions have been used in combination with work release programmes to rehabilitate offenders via a supportive environment over a relatively long period. This usually encompasses the transition between the prison and working within the community (Prendergast 2011). The ethos of a therapeutic community intervention is to focus on treatment on the whole self (and not on the drug abuse per se) and the underlying symptomatic problems, where the residents are instrumental in running the therapeutic community (Mitchell 2012a).

Cognitive behavioural approaches using programmes based on psychological theory have been employed to try to help people address their offending behaviour and generally have good support from the literature in their reduction of recidivism, but have previously excluded drug-using offenders (Andrews 1990; Lipsey 1998; Lipsey 2007).

Miller and Rollnick developed motivational interviewing as a process to motivate change in substance abusers (Miller 1991). The technique uses different strategies such as expressing empathy, avoiding arguing for change, and working on ambivalence to strengthen commitment to change. Meta-analyses evidence supports the use of motivational interviewing as a stand-alone treatment and in combination with more intensive programmes (Vasilaki 2006).

\section{Why it is important to do this review}

Many people under the care of the criminal justice system have cooccurring mental illness and drug-misuse problems. While previous research has evaluated treatment programmes for offenders more broadly, we know little about the challenges, treatment, and rehabilitation opportunities for offenders with co-occurring mental health and drug-misuse problems. We therefore believe that an evaluation of existing evidence on the impact of interventions for drug-using offenders with co-occurring mental illness might be helpful in identifying treatments for reducing drug use and criminal activity in this vulnerable population. Where possible, the review will also report descriptively on the costs of such treatment programmes.

\section{O B J E C T IVES}

To assess the effectiveness of interventions for drug-using offenders with co-occurring mental illness in reducing criminal activity or drug use, or both.

The review addressed the following questions:

1. Does any treatment for drug-using offenders with cooccurring mental illness reduce drug use?

2. Does any treatment for drug-using offenders with cooccurring mental illness reduce criminal activity?

3. Does the treatment setting (court, community, prison/ secure establishment) affect the intervention outcome(s)?

4. Does the type of treatment affect the outcome(s)?

Additionally, this review aimed to report on the cost and costeffectiveness of interventions.

\section{METHODS}

\section{Criteria for considering studies for this review}

\section{Types of studies}

Randomised controlled trials (RCTs).

\section{Types of participants}

We included drug-using offenders with co-occurring mental illness regardless of gender, age, or ethnicity. Drug misuse included any study that referred to participants who used occasionally, were dependent, or were known to abuse drugs. We defined offenders as participants who were involved in the criminal justice system. We judged offenders to have co-occurring mental illness where the paper explicitly stated this. We used several different mechanisms to identify study samples with mental health problems including:

1. use of diagnostic gold-standard tests such as the Diagnostic and Statistical Manual of Mental Disorders, Fourth Edition (DSM-IV) or International Statistical Classification of Diseases and Related Health Problems, Tenth Revision (ICD-10) criteria; or

2. the nature of the intervention (e.g. mental health court); or 
3. where the study described the participant demographic as having a "history of psychiatric illness" or "serious mental disorder" with a co-occurring substance misuse.

\section{Types of interventions}

Included interventions were designed, wholly or in part, to eliminate or prevent relapse to drug use or criminal activity, or both, among participants. We defined 'relapse' as participants who may have returned to an incarcerated setting or were subsequently arrested, or who had relapsed back into drug misuse, or both. We included a range of different types of interventions in the review.

\section{Experimental interventions included in the review}

1. Any pharmacological intervention (e.g. buprenorphine, methadone)

2. Any psychosocial intervention (e.g. therapeutic community, case management, cognitive behavioural therapy, interpersonal psychotherapy, motivational interviewing)

\section{Control interventions included in the review}

1. No treatment

2. Minimal treatment

3. Waiting list

4. Treatment as usual

5. Other treatment

\section{Types of outcome measures}

\section{Primary outcomes}

For the purpose of this review, we categorised our primary outcomes into those relating to dichotomous and continuous drug use or criminal activity, or both. Where papers reported a number of different follow-up periods, we reported the longest period, as we felt this measure was the most conservative estimate of effectiveness.

1. Drug use measures reported as:

i) self report drug use (unspecified drug, specific drug use not including alcohol, Addiction Severity Index composite scores);

ii) biological drug use (measured by drugs testing by either urine or hair analysis).

2. Criminal activity as measured by:

i) self report or official report of criminal activity (including arrest for any offence, drug offences, re-incarceration, convictions, charges, and recidivism).

\section{Secondary outcomes}

Our secondary outcome reported on cost or cost-effectiveness information. We used a descriptive narrative to describe these findings. We undertook a full critical appraisal based on the Drummond 1997 checklist for studies presenting sufficient information.

\section{Search methods for identification of studies}

\section{Electronic searches}

The update searches identified records from 2004 to May 2014.

- CENTRAL (issue 5, 2014) (Appendix 1)

- MEDLINE (1966 to May 2014) (Appendix 2)

- EMBASE (1980 to May 2014) (Appendix 3)

- PsycINFO (1978 to April 2014) (Appendix 4)

- PASCAL (1973 to November 2004) ${ }^{a}$ (Appendix 5)

- SciSearch (Science Citation Index) (1974 to April 2014)

(Appendix 5)

- Social SciSearch (Social Science Citation Index) (1972 to April 2014) (Appendix 5)

- ASSIA (1987 to April 2014) (Appendix 6)

- Wilson Applied Science and Technology Abstracts (1983 to October 2004) ${ }^{a}$

- Inside Conferences (1993 to November 2004) ${ }^{a}$

- Dissertation Abstracts (1961 to October 2004) ${ }^{a}$

- NTIS (1964 to April 2014)

- Sociological Abstracts (1963 to April 2014) (Appendix 7)

- HMIC (2004 to April 2014) (Appendix 8)

- PAIS (1972 to April 2014) (Appendix 9)

- SIGLE (1980 to June 2004) ${ }^{b}$ (Appendix 10)

- Criminal Justice Abstracts (1968 to April 2014) (Appendix 11)

- LILACS (2004 to April 2014)

- National Research Register (March 2004) ${ }^{c}$ (Appendix 12)

- Current Controlled Trials (December 2009)

- DrugScope (February 2004) - unable to access

- SPECTRA (March 2004) $)^{d}$ (Appendix 13)

${ }^{a}$ Unable to access further to 2004 search.

${ }^{b}$ Database not updated since original 2004 search.

${ }^{c}$ No longer exists.

${ }^{d}$ Now Campbell Collaboration searched online.

In our update of the original review we restricted the search strategy to studies that were published or unpublished from 2004 onwards (Perry 2006). We did not search several of the original databases for this update (indicated by the key at the end of the database list). We did not search PASCAL, ASSIA, Wilson Applied Science and Technology Abstracts, Inside Conferences, and Dissertation Abstracts, as these databases were available only via the fee-charging Dialog online host service, and we did not have the required 
resources. The National Research Register no longer exists, and SIGLE has not been updated since 2005. DrugScope is available only to subscribing members. The original searches were undertaken by DrugScope employees.

We developed search strategies for each database to employ the search engine most effectively and to make use of any controlled vocabulary. We designed search strategies to restrict the results to RCTs and placed no language restrictions. We included methodological search filters designed to identify trials. Whenever possible, we used filters retrieved from the InterTASC Information Specialists' Sub-Group Search Filter Resource site (www.york.ac.uk/ inst/crd/intertasc/). If filters were unavailable from this site, we used search terms based on existing filters instead.

In addition to the electronic databases, we searched relevant websites (Home Office, National Institute of Drug Abuse, and European Association of Libraries and Information Services on Alcohol and Other Drugs). We searched directory websites up to November 2011. We placed no language restrictions on identification and inclusion of studies in the review.

We have listed details of the update search strategies and results and websites searched in Appendix 1; Appendix 2; Appendix 3; Appendix 4; Appendix 5; Appendix 6; Appendix 7; Appendix 8; Appendix 9; Appendix 10; Appendix 11; Appendix 12; Appendix 13.

\section{Searching other resources}

\section{Reference checking}

We scrutinised the reference lists of all retrieved articles for additional references and searched the catalogues of relevant organisations.

\section{Personal communication}

We sought out experts for their knowledge of other published or unpublished studies relevant to the review.

\section{Data collection and analysis}

\section{Selection of studies}

Two review authors independently inspected titles and abstracts identified by the search strategy. We obtained each potentially relevant study as a full article, and two review authors independently assessed these for inclusion. In the case of discordance, a third review author arbitrated. One review author undertook translation of articles not written in the English language.

We divided the screening process into two key phases. Phase one used the initial eight key questions reported in the original review (Perry 2006).

\section{Phase one pre-screening criteria:}

1. Is the document an empirical study? [If no, exclude document]

2. Does the study evaluate an intervention, a component of which is designed to reduce, eliminate, or prevent relapse in drug-using offenders?

3. Are the participants referred by the criminal justice system at baseline?

4. Does the study report pre- and post-programme measures of drug use?

5. Does the study report pre- and post-programme measures of criminal behaviour?

6. Is the study an RCT?

7. Do the outcome measures refer to the same length of follow-up for two groups?

Following identification of relevant papers from phase one, we sought in phase two screening to identify those papers describing offenders with a mental illness. This information was primarily obtained from the participant description and the type of intervention (for example mental health drug court).

\section{Phase two pre-screening:}

1. Is the study population comprised wholly of participants with diagnosed mental illness using DSM-IV or ICD-10 diagnostic criteria? [if yes, include document]

2. Is the study population comprised wholly of participants identified on screening to have a mental health problem(s) based on intervention eligibility (e.g. mental health court)? [if yes, include document]

3. Where the full study population is not comprised of offenders with diagnosed or presumed mental illness, are separate results given for those participants with mental illness? [if no, exclude document]

Drug-using interventions were implied if the programme was targeted at reducing drug use in a group of individuals or could be ascertained from the background characteristics of the group. Offenders were individuals residing in special hospitals, prisons, the community, or who were diverted from court or placed on arrest referral schemes for treatment. We did accept papers in the review where the entire sample were not using drugs, but reported pre and post measures needed to be the same at both time points. The study setting could change throughout the process of the study. For example, offenders could begin in prison but progress through a work release project into a community setting. Finally, studies did not need to report both drug and criminal activity outcomes. If either of these were reported, we included the study in the review.

\section{Data extraction and management}

We used data extraction forms to standardise the reporting of data from all studies obtained as potentially relevant. Two review 
authors independently extracted data and subsequently checked them for agreement.

\section{Assessment of risk of bias in included studies}

Three review authors (AEP, MMSJ, RW) independently assessed risk of bias of all included studies using the 'Risk of bias' assessment criteria recommended in the Cochrane Handbook for Systematic Reviews of Interventions (Higgins 2011).

The recommended approach for assessing risk of bias in studies included in Cochrane reviews is a two-part tool, addressing seven specific domains, namely sequence generation and allocation concealment (selection bias), blinding of participants and providers (performance bias), blinding of outcome assessor (detection bias), incomplete outcome data (attrition bias), selective outcome reporting (reporting bias), and other source of bias. The first part of the tool involves describing what was reported to have happened in the study. The second part of the tool involves assigning a judgement relating to the risk of bias for that entry, in terms of low, high, or unclear risk. To make these judgements, we used the criteria indicated by the Cochrane Handbook for Systematic Reviews of Interventions adapted to the addiction field. See Appendix 14 for details.

The domains of sequence generation and allocation concealment (avoidance of selection bias) were addressed in the tool by a single entry for each study.

Blinding of participants, personnel, and outcome assessor (avoidance of performance bias and detection bias) were considered separately for objective outcomes (for example drop-out, use of substance of abuse measured by urine analysis, participants relapsed at the end of follow-up, participants engaged in further treatments) and subjective outcomes (for example duration and severity of signs and symptoms of withdrawal, participant self reported use of substance, side effects, social functioning as integration at school or at work, family relationship).

Incomplete outcome data (avoidance of attrition bias) was considered for all outcomes except for drop-out from the treatment, which is very often the primary outcome measure in trials on addiction.

For studies identified in the search, the review authors attempted to contact study authors to establish whether a study protocol was available.

\section{Measures of treatment effect}

The mean differences (MD) were used for outcomes measured on the same scale and the standardised mean difference (SMD) was used for outcomes measured on different scales. Higher scores for continuous measures are representative of greater harm. We presented dichotomous outcomes as risk ratios (RR), with 95\% confidence intervals (CIs).

\section{Unit of analysis issues}

To avoid double counting of outcome measures (for example arrest and parole violation) and follow-up time periods (for example 12, 18 months), we checked all trials to ensure that multiple studies reporting the same evaluation did not contribute towards multiple estimates of program effectiveness. We followed Cochrane guidance, and where appropriate we combined intervention and control groups to create a single pair-wise comparison. Where this was not appropriate, we selected one treatment arm and excluded the others.

\section{Dealing with missing data}

We attempted to contact study authors via email where missing data occurred in the original publication.

\section{Assessment of heterogeneity}

We assessed heterogeneity using the $\mathrm{I}^{2}$ statistic and $\mathrm{Chi}^{2}$ statistic (Higgins 2011).

\section{Data synthesis}

We planned to use the RevMan software package to perform a series of meta-analyses for continuous and dichotomous outcome measures (RevMan 2012). We planned to use a random-effects model to account for the fact that participants did not come from a single underlying population. Because of the high heterogeneity of included studies for types of intervention compared, no metaanalysis were performed. The narrative tables included a presentation of the study details (for example author, year of publication, and country of study origin), study methods (for example random assignment), participants (for example number in sample, age, gender, ethnicity, age, mental health status), interventions (for example description, duration, intensity, and setting), outcomes (for example description, follow-up period, and reporting mechanism), resource and cost information and resource savings (for example number of staff, intervention delivery, estimated costs, and estimated savings) and notes (for example methodological and quality assessment information).

\section{Subgroup analysis and investigation of heterogeneity}

We had planned to conduct sensitivity analyses to assess the impact of studies at high risk of bias compared with those at low or unclear risk of bias. Because of the overall high risk of bias of the included studies, this analysis was not possible.

\section{RES U L T S}

Interventions for drug-using offenders with co-occurring mental illness (Review)

Copyright @ 2015 The Cochrane Collaboration. Published by John Wiley \& Sons, Ltd. 


\section{Description of studies}

\section{Results of the search}

\section{Original review}

The original searches spanned from database inception to October 2004. They identified a total of 8217 records after duplication. We acquired a total of 90 full-text papers for assessment and excluded 36 papers, bringing 24 trials to the review (see Figure 1).

Figure I. Study flow diagram of paper selection process: Original Review

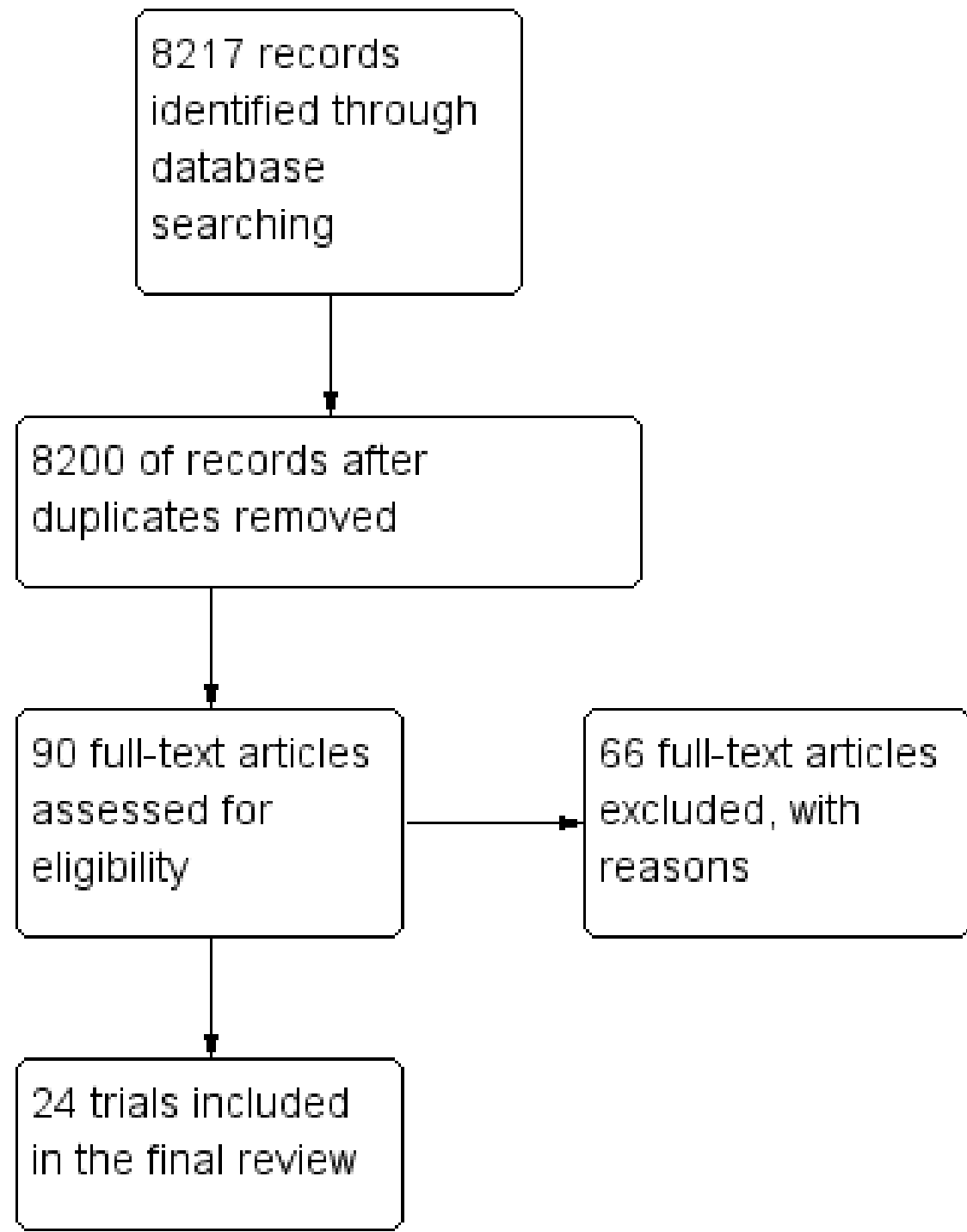




\section{First update}

The updated searches spanned from October 2004 until March 2013. These identified a total of 3896 records after duplication. We acquired a total of 109 full-text papers for assessment and excluded 104 papers, bringing 5 new trials to the review (see Figure 2).

Figure 2. Study flow diagram of paper selection process: First update

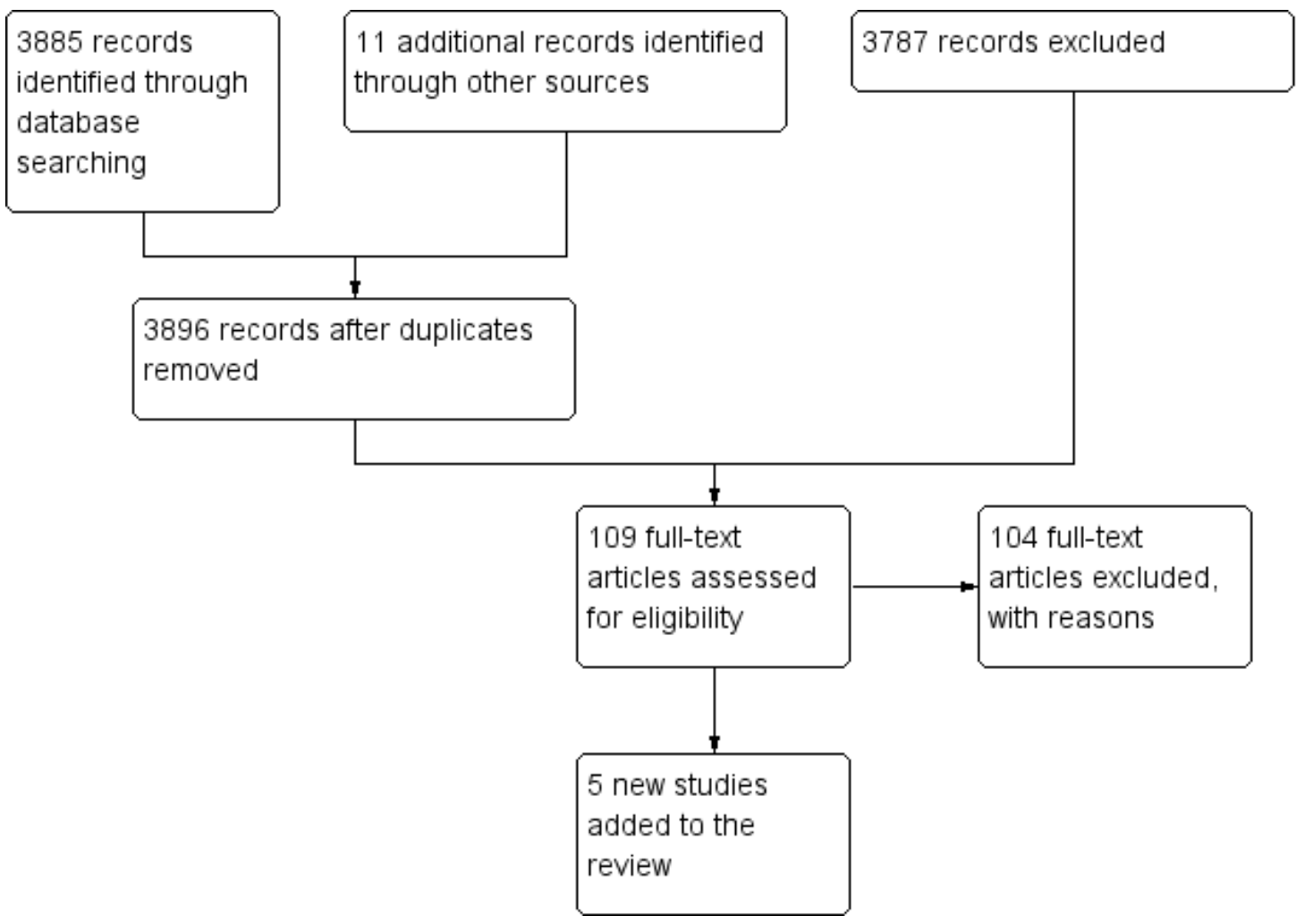

\section{Second update}

The updated searches spanned from March 2013 until April 2014. These identified a total of 2092 records after duplication. We acquired a total of 72 full-text papers for assessment and excluded 69 papers, bringing 3 new trials to the review, making a total of 14 publications represented by 8 trials (see Figure 3 ). 
Figure 3. Study flow diagram of paper selection process: Second update

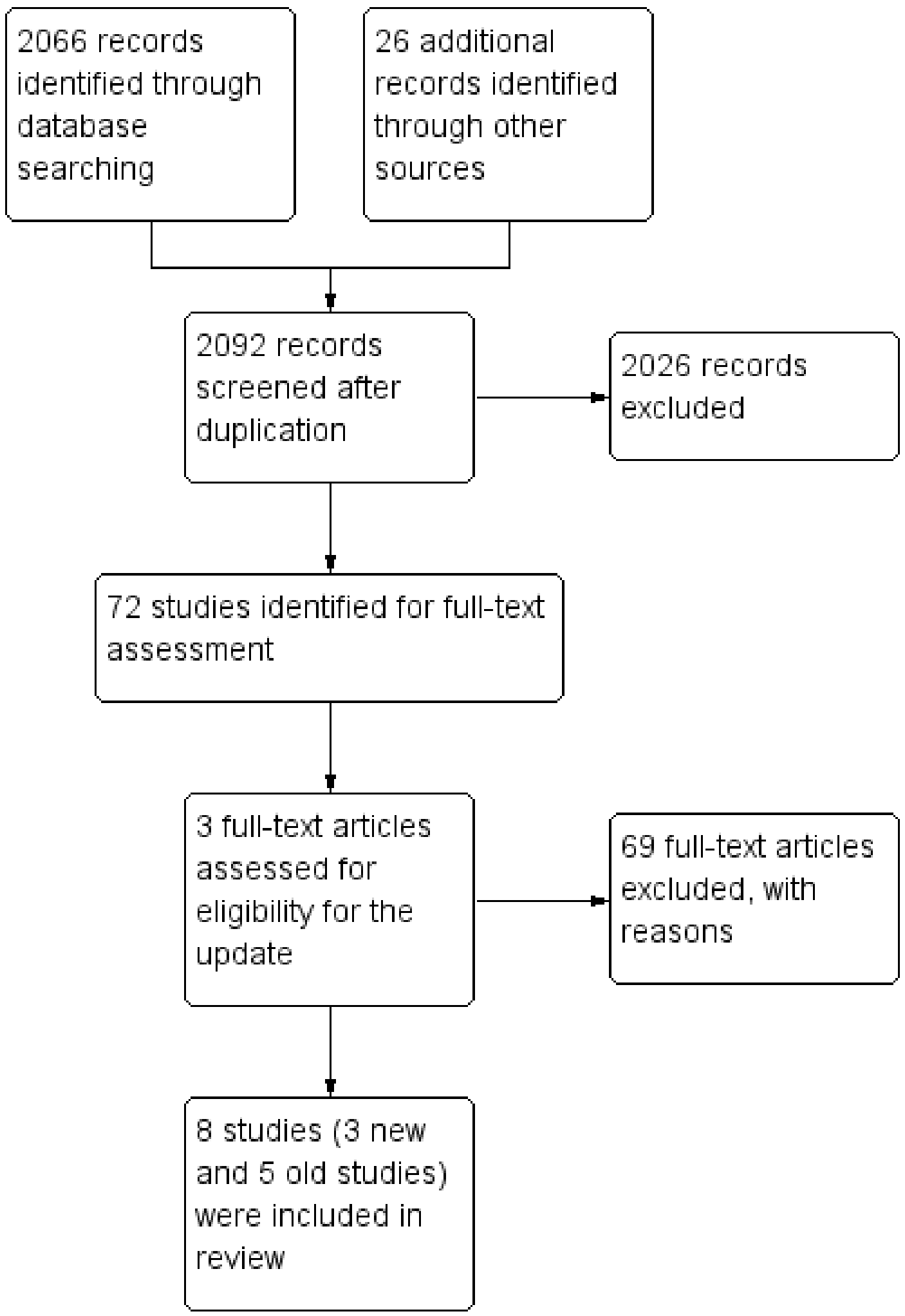




\section{Included studies}

Fourteen publications represented eight trials published between 1999 and 2014. The eight trials consisted of three singular trial publications on different interventions, Cosden 2003, Sacks 2011, and Stein 2011, and two trials represented by five publications. The first trial represented an evaluation of one intervention to two comparison groups, using different outcome measures (drug use at 12 months reported by Sacks 2004). The second trial represented three publications and four comparisons presenting follow-up data successively between 12 and 60 months (Wexler 1999).

\section{Treatment regimens and settings}

Six studies were conducted in a secure setting. The evaluations considered a therapeutic community intervention and aftercare in comparison to some alternative-sentencing option (Johnson 2012; Lanza 2013; Sacks 2004; Sacks 2008; Sacks 2011; Wexler 1999). Two studies were conducted in a court setting. The evaluations compared assertive case management versus treatment as usual in a mental health drug court (Cosden 2003), and motivational interviewing with relaxation training in a group of adolescents with significant depression (Stein 2011).

No studies assessed the efficacy of pharmacological treatments.

No studies were identified in the community.

\section{Countries in which the studies were conducted}

All the studies were published in the US.

\section{Duration of trials}

The trial duration varied between 3 months' follow-up, in Johnson 2012, Lanza 2013, and Stein 2011, to a 5-year follow-up (Wexler 1999). The remaining studies reported on outcomes at 12, 24, and 36 months (Cosden 2003; Sacks 2011; Sacks 2008; Sacks 2004).

\section{Participants}

Seven of the eight comparisons included adult drug-using offenders. One study investigated the impact of motivational interviewing in adolescents aged 14 to 19 years (Stein 2011).

Three studies included female offenders (Cosden 2003; Johnson 2012; Stein 2011). Adult male offenders were the focus of the study populations in the majority of studies, with a mean age of 30 years.

In all study populations, the majority of participants were of white ethnic origin.

Mental health diagnoses varied across the studies (see Table 1 for more information).

\section{Excluded studies}

We excluded 172 studies. (See Characteristics of excluded studies for further details.) Reasons for exclusion were: lack of criminal justice involvement in referral to the intervention; not reporting relevant drug or crime outcome measures or both at both the preand post-intervention periods; and allocation of participants to study groups that were not strictly randomised or did not contain original trial data. We excluded the majority of studies because the study population were not offenders. We excluded one study because follow-up periods were not equivalent across study groups (Di Nitto 2002), and another because the study intervention (acupuncture) did not measure our specified outcomes of drug use or criminal activity (Berman 2004). One study reported the protocol of a trial only (Baldus 2011), while another only contained conference proceedings (Kinlock 2009). For one trial, we were unable to obtain the data (Cogswell 2011), and for another we were unable to obtain the full-text version (Rowan-Szal 2005).

\section{Risk of bias in included studies}

\section{Allocation}

\section{Randomisation}

All of the nine included comparisons were described as randomised. Five of the included studies reported on how the randomisation sequence was generated and were judged as at low risk of bias (Cosden 2003; Johnson 2012; Lanza 2013; Sacks 2011; Stein 2011). The remaining three studies did not report how the randomisation sequence of participants was generated (Sacks 2004; Sacks 2008; Wexler 1999).

\section{Characteristics at baseline}

Five of the eight studies were similar on drug use at baseline ( Johnson 2012; Sacks 2004; Sacks 2008; Sacks 2011; Stein 2011), two studies were rated unclear (Cosden 2003; Lanza 2013), and one study showed comparable baseline differences (Sacks 2004). For similarity on criminal justice measures, six studies were rated as similar (Cosden 2003; Johnson 2012; Sacks 2008; Sacks 2011; Sacks 2004; Stein 2011; Wexler 1999), and two were rated as unclear (Lanza 2013; Stein 2011).

\section{Allocation concealment}

Of the eight studies, only one adequately reported that the allocation process was concealed (Johnson 2012). 


\section{Blinding}

We assessed blinding across four dimensions considering performance and detection bias across subjective and objective measures (see Appendix 14). For five of the eight studies, we considered blinding unclear on all four measures of blinding (Sacks 2004; Sacks 2008; Stein 2011; Wexler 1999). We rated one study as at high risk of bias on two of the four measures (Cosden 2003), and we rated another study as at low risk of bias across three of the four domains (Lanza 2013).

\section{Incomplete outcome data}

Loss to follow-up was reported to differing extents in the included studies. We rated two studies as at low risk of bias (Cosden 2003; Sacks 2008), and we rated four as at low risk with limited attrition noted (Johnson 2012; Lanza 2013; Sacks 2004; Wexler 1999). We rated two studies as unclear (Sacks 2011; Stein 2011).

\section{Selective reporting}

We rated five of the eight trials as unclear (Cosden 2003; Sacks 2004; Sacks 2011; Stein 2011; Wexler 1999). We rated two studies as at low risk (Lanza 2013; Sacks 2008), and we rated one study as at high risk (Johnson 2012).

\section{Other potential sources of bias}

Of the eight studies, we rated four as at high risk of other bias (Cosden 2003; Johnson 2012; Stein 2011; Wexler 1999), three as at low risk with no further concerns (Lanza 2013; Sacks 2008; Sacks 2011), and the final study as unclear (Sacks 2004).

See Figure 4 and Figure 5 for more details.

Figure 4. Risk of bias graph: review authors' judgements about each risk of bias item presented as percentages across all included studies.

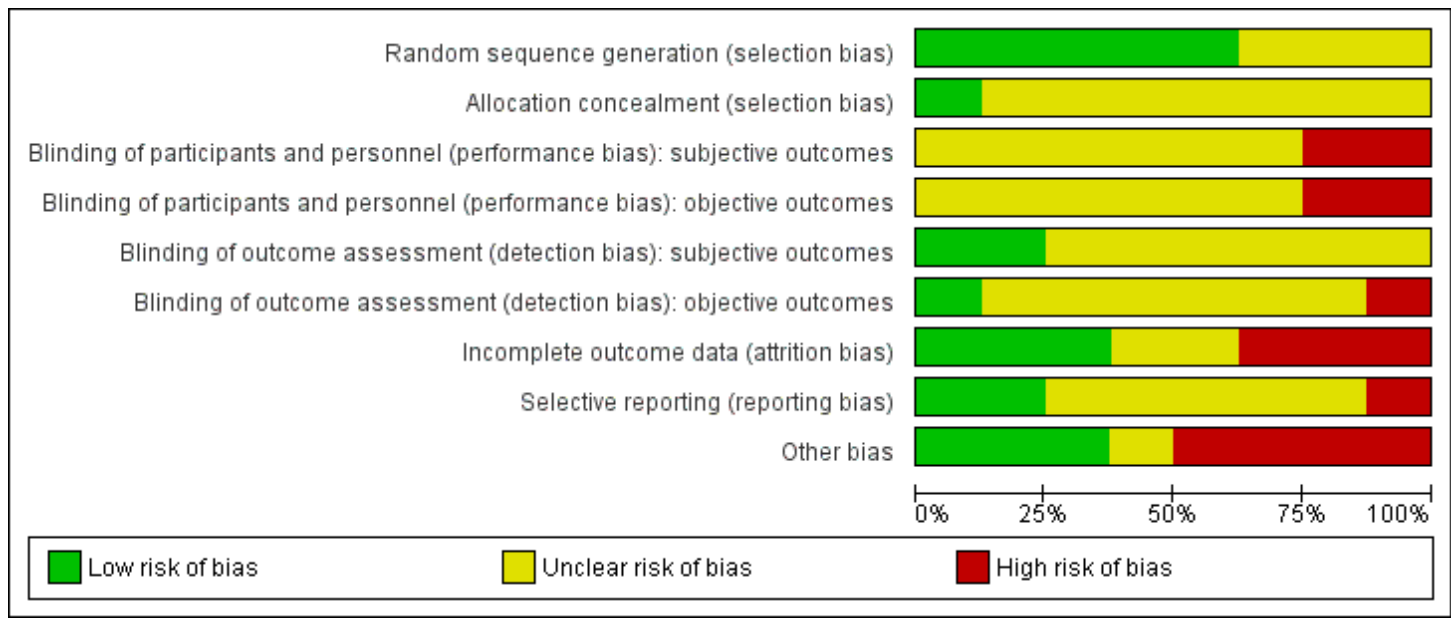


Figure 5. Risk of bias summary: review authors' judgements about each risk of bias item for each included study.

\begin{tabular}{|c|c|c|c|c|c|c|c|c|c|}
\hline & 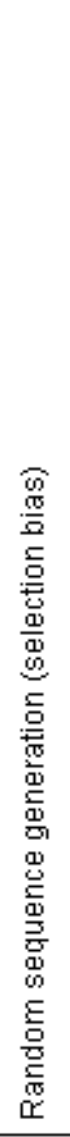 & 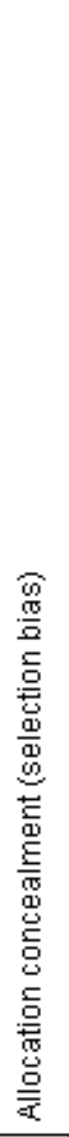 & 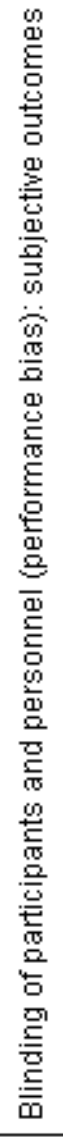 & 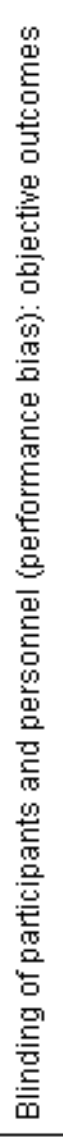 & 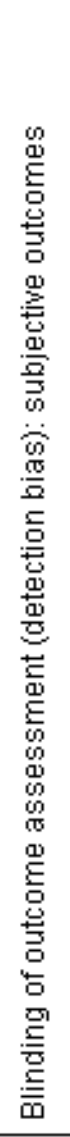 & 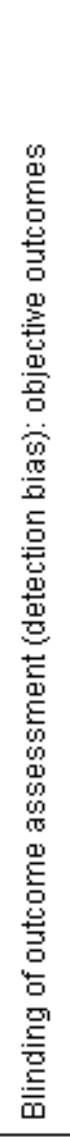 & 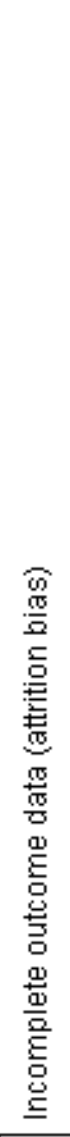 & 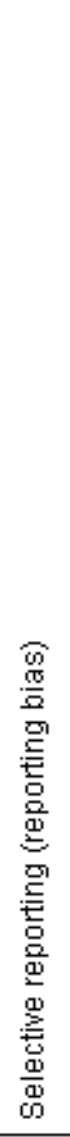 & 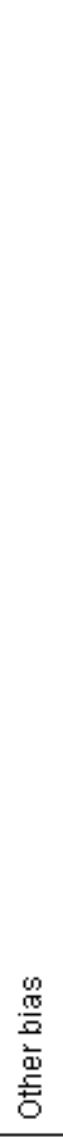 \\
\hline Cosden 2003 & 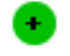 & $?$ & - & - & $?$ & $?$ & $\odot$ & $?$ & \\
\hline Johnson 2012 & + & $\oplus$ & $?$ & $?$ & + & + & $\oplus$ & $\odot$ & \\
\hline Lanza 2013 & + & $?$ & - & $\odot$ & + & $\odot$ & + & + & 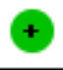 \\
\hline Sacks 2004 & $?$ & $?$ & $?$ & $?$ & $?$ & $?$ & & $?$ & $?$ \\
\hline Sacks 2008 & $?$ & $?$ & $?$ & $?$ & $?$ & $?$ & - & 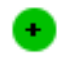 & + \\
\hline Sacks 2011 & 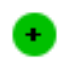 & $?$ & $?$ & $?$ & $?$ & $?$ & $?$ & $?$ & + \\
\hline Stein 2011 & + & $?$ & $?$ & $?$ & $?$ & $?$ & $?$ & $?$ & \\
\hline Wexler 1999 & $?$ & $?$ & $?$ & $?$ & $?$ & $?$ & + & $?$ & \\
\hline
\end{tabular}




\section{Effects of interventions}

See: Summary of findings for the main comparison Therapeutic community for drug-using offenders with co-occurring mental illness; Summary of findings 2 Mental health court for drug-using offenders with co-occurring mental illness; Summary of findings 3 Motivational interviewing and cognitive skills for drug-using offenders with co-occurring mental illness; Summary of findings 4 Interpersonal psychotherapy for drug-using offenders with cooccurring mental illness

We considered each of our studies in relation to the key objectives of the review and grouped them together by outcome measures and individual intervention type (see Table 2 for more details). We have summarised the main comparisons in Summary of findings for the main comparison; Summary of findings 2 .

Due to high heterogeneity of the interventions compared in the included studies, it was not possible to combine study results, and we performed no meta-analyses for drug use measures and criminal activities. Furthermore as all the included studies were conducted in a secure or court setting, it was not possible to combine study results, and we performed no meta-analyses.

I. Therapeutic community and aftercare versus treatment as usual

See Summary of findings for the main comparison

\section{Impact on self report drug use}

Three studies reported results about self report drug use. One study found statistically significant reduction: Sacks 2004 (RR $0.58,95 \%$ CI 0.36 to $0.93,139$ participants); the second study found nearly statistically significant reduction: Sacks 2008 (RR $0.73,95 \%$ CI 0.53 to $1.01,370$ participants); while the third study found no statistically significant reduction: Wexler 1999 (RR $1.11,95 \%$ CI 0.82 to $1.49,576$ participants).

\section{Impact on criminal activity}

Two studies reported no statistically significant reduction in rearrest following treatment: Sacks 2008 (RR 1.65, 95\% CI 0.83 to $3.28,370$ participants); and Wexler 1999 comparing a secure establishment-based therapeutic community program versus no treatment (RR $0.96,95 \%$ CI 0.82 to $1.13,428$ participants), moderate quality of evidence; see Analysis 1.1

Three studies evaluated the impact of therapeutic community treatment using re-incarceration measures. Two studies reported statistically significant reduction: Sacks 2004 comparing Personal Reflections therapeutic community and voluntary residential aftercare versus mental health programme (RR $0.28,95 \% \mathrm{CI} 0.13$ to
0.63, 139 participants); and Sacks 2011 comparing re-entry modified therapeutic community treatment versus parole supervision case management (RR 0.49, 95\% CI 0.27 to $0.89,127$ participants). One study did not find statistically significant results: Sacks 2008 comparing a therapeutic community program versus cognitive behavioural intervention (RR $0.73,95 \%$ CI 0.45 to 1.19 , 370 participants), moderate quality of evidence, see Analysis 1.1

\section{Mental health court and case management versus treatment as usual (standard court proceedings)}

SeeSummary of findings 2

\section{Impact on self report drug use}

The study did not assess this outcome.

\section{Impact on self report criminal activity}

One study reported no statistically significant reduction in criminal activity: RR 1.05, 95\% CI 0.90 to $1.22,235$ participants (Cosden 2003), very low quality of evidence, see Analysis 2.1

\section{Motivational interviewing and cognitive skills versus relaxation therapy}

SeeSummary of findings 3

\section{Impact on self report drug use--continuous}

One study reported no statistically significant reduction in self report drug use: MD $-7.42,95 \%$ CI -20.12 to $5.28,162$ participants (Stein 2011), low quality of evidence, see Analysis 3.1

\section{Impact on self report drug use--dichotomous}

One study reported no statistically significant reduction in self report drug use: RR $0.92,95 \%$ CI 0.36 to 2.33 , 41 participants (Lanza 2013), very low quality of evidence, see Analysis 3.2

\section{Impact on self report criminal activity}

The studies did not assess this outcome.

\section{Interpersonal psychotherapy versus a psycho-educational intervention}

See Summary of findings 4 


\section{Impact on self report drug use}

One study reported no statistically significant reduction in self report drug use: RR $0.67,95 \%$ CI 0.30 to $1.50,38$ participants (Johnson 2012), very low quality of evidence, see Analysis 4.1

\section{Impact on self report criminal activity}

The studies did not assess this outcome.

\section{Cost and cost-effectiveness}

Four papers referred to the costs or cost-effectiveness of the therapeutic community programmes. The Sacks 2011 paper suggested that cost-beneficial analyses associated with each intervention in achieving the desired outcome would greatly assist how best to allocate scarce resources. The Prendergast five-year evaluation presents economic differences when compared to the one-year Amity outcome study. The Prendergast research suggests that optimal cost savings appear to require prison treatment plus aftercare rather than prison treatment alone (McCollister 2013). One study contained some information about cost, but not sufficient to conduct a cost-effectiveness appraisal (Sacks 2004). The authors of this study noted that the additional marginal costs on top of the specific incarceration costs were USD7.37 per day, compared with the USD148.19 cost of a prison day. This suggests a substantial cost saving of using therapeutic community programmes as opposed to prison. 
ADDITIONAL SUMMARY OF F INDINGS [Explanation]

Mental health court for drug-using offenders with co-occurring mental illness

Patient or population: drug-using offenders with co-occurring mental illness

Settings:

Intervention: Mental health court

\begin{tabular}{|c|c|c|c|c|c|c|}
\hline \multirow[t]{3}{*}{ Outcomes } & \multicolumn{2}{|c|}{ Illustrative comparative risks* $(95 \% \mathrm{CI})$} & \multirow{3}{*}{$\begin{array}{l}\text { Relative effect } \\
(95 \% \text { CI) }\end{array}$} & \multirow{3}{*}{$\begin{array}{l}\text { No of Participants } \\
\text { (studies) }\end{array}$} & \multirow{3}{*}{$\begin{array}{l}\text { Quality of the evidence } \\
\text { (GRADE) }\end{array}$} & \multirow[t]{3}{*}{ Comments } \\
\hline & Assumed risk & Corresponding risk & & & & \\
\hline & Control & Mental health court & & & & \\
\hline \multirow{4}{*}{$\begin{array}{l}\text { Self report dichotomous } \\
\text { criminal activity } \\
\text { Follow-up: mean } 12 \\
\text { months }\end{array}$} & Study populati & & \multirow{4}{*}{$\begin{array}{l}\text { RR } 1.05 \\
(0.9 \text { to } 1.22)\end{array}$} & \multirow{4}{*}{$\begin{array}{l}208 \\
\text { (1 study) }\end{array}$} & \multirow{4}{*}{$\begin{array}{l}\oplus \bigcirc \bigcirc \bigcirc \\
\text { very low }{ }^{1,2}\end{array}$} & \multirow[t]{4}{*}{--} \\
\hline & 724 per 1000 & $\begin{array}{l}761 \text { per } 1000 \\
\text { (652 to } 884)\end{array}$ & & & & \\
\hline & \multicolumn{2}{|l|}{ Moderate } & & & & \\
\hline & 725 per 1000 & $\begin{array}{l}761 \text { per } 1000 \\
\text { (652 to } 885)\end{array}$ & & & & \\
\hline
\end{tabular}

*The basis for the assumed risk (e.g. the median control group risk across studies) is provided in footnotes. The corresponding risk (and its $95 \%$ confidence interval) is based on the assumed risk in the comparison group and the relative effect of the intervention (and its $95 \% \mathrm{Cl}$ ).

Cl: confidence interval; RR: risk ratio

GRADE Working Group grades of evidence

High quality: Further research is very unlikely to change our confidence in the estimate of effect.

Moderate quality: Further research is likely to have an important impact on our confidence in the estimate of effect and may change the estimate.

Low quality: Further research is very likely to have an important impact on our confidence in the estimate of effect and is likely to change the estimate.

Very low quality: We are very uncertain about the estimate.

${ }^{1} 4$ of the 9 items were rated as high risk; 4 of the 9 items were rated as unclear risk.

2 Only 1 study with 208 participants 


\begin{tabular}{|c|c|c|c|c|c|c|}
\hline \multicolumn{7}{|c|}{ Motivational interviewing and cognitive skills for drug-using offenders with co-occurring mental illness } \\
\hline \multicolumn{7}{|c|}{$\begin{array}{l}\text { Patient or population: drug-using offenders with co-occurring mental illness } \\
\text { Settings: } \\
\text { Intervention: Motivational interviewing and cognitive skills }\end{array}$} \\
\hline \multirow[t]{3}{*}{ Outcomes } & \multicolumn{2}{|c|}{ Illustrative comparative risks* $(95 \% \mathrm{Cl})$} & \multirow{3}{*}{$\begin{array}{l}\text { Relative effect } \\
(95 \% \mathrm{Cl})\end{array}$} & \multirow{3}{*}{$\begin{array}{l}\text { No of Participants } \\
\text { (studies) }\end{array}$} & \multirow{3}{*}{$\begin{array}{l}\text { Quality of the evidence } \\
\text { (GRADE) }\end{array}$} & \multirow[t]{3}{*}{ Comments } \\
\hline & Assumed risk & Corresponding risk & & & & \\
\hline & Control & $\begin{array}{l}\text { Motivational interview- } \\
\text { ing and cognitive skills }\end{array}$ & & & & \\
\hline $\begin{array}{l}\text { Self report drug use con- } \\
\text { tinuous } \\
\text { Follow-up: mean } 3 \\
\text { months }\end{array}$ & -- & $\begin{array}{l}\text { The mean self report drug } \\
\text { use continuous in the in- } \\
\text { tervention groups was } \\
7.42 \text { lower } \\
\text { (20.12 lower to } 5.28 \\
\text { higher) }\end{array}$ & - & $\begin{array}{l}162 \\
\text { (1 study) }\end{array}$ & $\begin{array}{l}\oplus \oplus \bigcirc \bigcirc \\
\text { low }^{1,2}\end{array}$ & -- \\
\hline \multirow{4}{*}{$\begin{array}{l}\text { Self report drug use di- } \\
\text { chotomous } \\
\text { Follow-up: mean } 3 \\
\text { months }\end{array}$} & Study populati & & \multirow{4}{*}{$\begin{array}{l}\text { RR } 0.92 \\
\text { (0.36 to 2.33) }\end{array}$} & \multirow{4}{*}{$\begin{array}{l}41 \\
\text { (1 study) }\end{array}$} & \multirow{4}{*}{$\begin{array}{l}\oplus \bigcirc \bigcirc \bigcirc \\
\text { very low }\end{array}$} & \multirow[t]{4}{*}{--} \\
\hline & 364 per 1000 & $\begin{array}{l}\mathbf{3 3 5} \text { per } \mathbf{1 0 0 0} \\
\text { (131 to } 847)\end{array}$ & & & & \\
\hline & Moderate & & & & & \\
\hline & 364 per 1000 & $\begin{array}{l}\mathbf{3 3 5} \text { per } \mathbf{1 0 0 0} \\
\text { (131 to } 848 \text { ) }\end{array}$ & & & & \\
\hline
\end{tabular}

*The basis for the assumed risk (e.g. the median control group risk across studies) is provided in footnotes. The corresponding risk (and its $95 \%$ confidence interval) is based on the assumed risk in the comparison group and the relative effect of the intervention (and its $95 \% \mathrm{Cl}$ ).

Cl: confidence interval; RR: risk ratio 
GRADE Working Group grades of evidence

High quality: Further research is very unlikely to change our confidence in the estimate of effect.

Moderate quality: Further research is likely to have an important impact on our confidence in the estimate of effect and may change the estimate.

Low quality: Further research is very likely to have an important impact on our confidence in the estimate of effect and is likely to change the estimate.

Very low quality: We are very uncertain about the estimate.

${ }^{1} 1$ of 9 items judged as high risk; 7 of 9 items judged as unclear risk.

2 Only 1 study with 162 participants.

33 of 9 items rated as high risk; 1 of 9 rated as unclear risk.

${ }^{4}$ Only 1 study with 41 participants. 
Interpersonal psychotherapy for drug-using offenders with co-occurring mental illness

Patient or population: drug-using offenders with co-occurring mental illness

Settings:

Intervention: Interpersonal psychotherapy

\begin{tabular}{|c|c|c|c|c|c|c|}
\hline \multirow[t]{3}{*}{ Outcomes } & \multicolumn{2}{|c|}{ Illustrative comparative risks* $(95 \% \mathrm{CI})$} & \multirow{3}{*}{$\begin{array}{l}\text { Relative effect } \\
(95 \% \mathrm{Cl})\end{array}$} & \multirow{3}{*}{$\begin{array}{l}\text { No of Participants } \\
\text { (studies) }\end{array}$} & \multirow{3}{*}{$\begin{array}{l}\text { Quality of the evidence } \\
\text { (GRADE) }\end{array}$} & \multirow[t]{3}{*}{ Comments } \\
\hline & Assumed risk & Corresponding risk & & & & \\
\hline & Control & $\begin{array}{l}\text { Interpersonal } \\
\text { psychotherapy }\end{array}$ & & & & \\
\hline \multirow{4}{*}{$\begin{array}{l}\text { Self report drug use di- } \\
\text { chotomous } \\
\text { Follow-up: mean } 3 \\
\text { months }\end{array}$} & Study populati & & \multirow{4}{*}{$\begin{array}{l}\mathbf{R R} \mathbf{0 . 6 7} \\
(0.3 \text { to } 1.5)\end{array}$} & \multirow{4}{*}{$\begin{array}{l}38 \\
(1 \text { study })\end{array}$} & \multirow{4}{*}{$\begin{array}{l}\oplus \bigcirc \bigcirc \bigcirc \\
\text { very low }\end{array}$} & \\
\hline & 474 per 1000 & $\begin{array}{l}317 \text { per } 1000 \\
\text { (142 to } 711)\end{array}$ & & & & \\
\hline & \multicolumn{2}{|l|}{ Moderate } & & & & \\
\hline & 474 per 1000 & $\begin{array}{l}318 \text { per } 1000 \\
\text { (142 to } 711)\end{array}$ & & & & \\
\hline
\end{tabular}

*The basis for the assumed risk (e.g. the median control group risk across studies) is provided in footnotes. The corresponding risk (and its $95 \%$ confidence interval) is based on the assumed risk in the comparison group and the relative effect of the intervention (and its $95 \% \mathrm{Cl}$ ).

Cl: confidence interval; RR: risk ratio

GRADE Working Group grades of evidence

High quality: Further research is very unlikely to change our confidence in the estimate of effect.

Moderate quality: Further research is likely to have an important impact on our confidence in the estimate of effect and may change the estimate.

Low quality: Further research is very likely to have an important impact on our confidence in the estimate of effect and is likely to change the estimate.

Very low quality: We are very uncertain about the estimate.

2 of 9 items rated as high risk; 2 of 9 items rated as unclear risk.

${ }^{2}$ Only 1 study with 38 participants. 


\section{DISCUSSION}

\section{Summary of main results}

This systematic review provided evidence from eight trials. The trials were conducted in secure settings and the court judicial system. We did not identify any studies that evaluated interventions for drug-using offenders with co-occurring mental illness in the community who were on parole or under the care of the probation service. We therefore do not know whether such interventions work better in one setting as opposed to another. Four different types of treatment interventions were classified across the studies. These were divided into: case management via a mental health drug court, therapeutic community treatment, motivational interviewing with cognitive skills in comparison to relaxation training, and interpersonal psychotherapy in comparison to a psychoeducational intervention. The therapeutic community studies reported statistically significant reductions in subsequent re-incarceration, but not for re-arrest. This finding supports previous research that demonstrates that the combination of therapeutic community treatment and aftercare release seem to produce the most consistent and successful results Mitchell 2012a. Though not addressed within this review, those clients also remained in treatment for the longest period appeared to benefit the most (Sacks 2004). One of the included studies was specifically adapted therapeutic community treatment for women offenders. This study compared women assigned to therapeutic community treatment or standard treatment, a cognitive behavioural recovery and relapse prevention curriculum referred to in the system as the Intensive Outpatient Program (Sacks 2008). At six months the study found that both groups improved significantly on variables of mental health, substance use, criminal behaviour, and HIV risk. The authors note that further exploration of each model for different offender groups is required to permit a more precise utility of each model. The authors conclude that these preliminary findings suggest the importance of providing gender-specific sensitive and comprehensive approaches within the correctional system to respond to the complex substance abuse needs of female offenders (Sacks 2008). The more recent follow-up study investigated outcomes at 6 and 12 months. The outcomes followed a similar pattern, with both groups of women benefiting from treatment. Therapeutic community treatment was found to be more beneficial than cognitive behavioural therapy at improving re-incarceration rates and lengthening the amount of time spent in the community before subsequent re-incarceration (Sacks 2008).

We noted no statistically significant reductions for criminal activity or self report drug use with the use of case management via a mental health court; motivational interviewing with cognitive skills over relaxation training; and acceptance and commitment therapy (ACT)or interpersonal psychotherapy (Cosden 2003; Johnson 2012; Lanza 2013; Stein 2011). The interpersonal psychotherapy was evaluated using a pilot study of women suffering from ma- jor depression and substance use disorder (Johnson 2012). This study is primarily a feasibility study to assess the applicability of using interpersonal psychotherapy in a prison environment. While small, it is in fact one of the largest trials including women with co-occurring substance misuse and mental health problems. The findings showed that participants undergoing interpersonal psychotherapy had significantly reduced levels of depression and substance misuse over the attention-matched control. The study evaluating ACT in comparison to traditional cognitive behavioural therapy found higher levels of abstinence in the ACT (43.8\%) when compared to the control (18.2\%). These findings are similar to other studies that have used ACT albeit in non-incarcerated populations (Hayes 2004). The authors attribute the success of ACT to the nature of the 'co-joint' work between the therapist and client, the aim of which is to increase the flexibility and structure of the therapy allowing the client to have greater autonomy over decision-making. They argue that cognitive behavioural therapy is in contrast more systematically directed by the therapist, leaving little scope for responsive change (Lanza 2013). In summary, the studies varied greatly in nature, and given that they represent a series of singular trials, caution is called for in interpreting their results.

The impact on criminal-activity outcome measures varied, and the differences noted between the reductions in re-incarceration but not re-arrest could be a reflection of the measurement processes. For example, incarceration to prison is a longer process involving a court case, and as a numerical outcome measure is less likely to be recorded within the time frame of an experimental evaluation. In comparison, 'arrest' as a measurement outcome is more frequent and is recorded in the criminal justice system within a shorter time frame. Sacks 2011 also argues that participation in different treatment options does not necessarily lead to less involvement with the criminal justice system, but that the severity of the offences are reduced such that re-incarceration is less likely. The follow-up studies to the Wexler trial also commented on differential effectiveness of treatment outcomes (Prendergast 2003; Prendergast 2004). The authors argue that focusing on only one or two outcomes may mask the impact of treatment on other outcome domains that are of interest to various stakeholders. For example, measuring re-arrest or re-incarceration does not reveal the reason for why an individual has returned to correctional supervision. Questions that remain unanswered through such measurement include (i) the length of time an offender remains in the community until re-arrest, (ii) knowledge about what crimes are committed, and (iii) the reasons for return.

In terms of addressing some of the complex issues of individuals with mental illness and co-occurring substance abuse, the evidence from this systematic review provides little information. Only three studies discussed the differential treatment effects on the severity of depression (Cosden 2003; Johnson 2012; Stein 2011). The Cosden 2003 study noted that further understanding of how to help clients with serious mental illness with different levels of 
treatment is needed. The Johnson 2012 study noted that participants undergoing interpersonal psychotherapy had significantly reduced levels of depression and substance misuse over the attention-matched control. The authors noted that the intensity of treatment delivered once the individual is released into the community is key to maintaining good outcomes. However, they go on to state that women often experience delays in treatment and service provision on release, and they suggest that alternative service provision such as phone treatment might be helpful in providing a more intensive post-release treatment and useful in times of crisis.

Several successful treatment elements were reported throughout the five trials with a number of key themes identified. First, we noted the issue of treatment engagement as important. In the mental health court trial, the informal support from family and friends encouraged the engagement of clients within the community to longer term gain (Cosden 2003). Second, programmes that were specifically adapted to the needs of mental health clients tended to include a cognitive behavioural curriculum that emphasised criminal thinking and behaviour alongside psycho-educational classes. The focus of combining these two types of mechanisms is to enhance an individuals ability to recognise and understand their substance misuse and mental health problems in more detail (Sacks 2004). Third, the longer an individual is engaged in treatment the better the outcome(s) (Wexler 1999).

\section{Overall completeness and applicability of evidence}

\section{General applicability}

The applicability of the evidence is hindered in general by the lack of trials covering a range of different treatment options for drugusing offenders with co-occurring mental illness. As the trials were conducted in the US judicial system, they are, therefore, limited in their generalisation to other criminal justice systems outside of the US. The current evidence suggests that therapeutic community treatment may have some effect in reducing re-incarceration rates, but we do not know how such treatment facilitates the specific rehabilitation requirements of drug-using offenders with co-occurring mental illness, and the studies represent singular outcomes. For drug use measures, the review only reports on self report drug use, as not enough information using biological outcome measures of drug use (for example hair and urine analysis) was available. As a result, the self report information must be interpreted with caution. In addition, we can say nothing about whether the treatments are effective in reducing drug use and subsequent criminal behaviour while offenders are on parole or on probation in the community.

\section{Mental health information}

Although the review specifically sought to identify studies including participants with co-occurring mental illness, the study descriptions of mental ill health varied (see Table 1). The Cosden 2003 study used a psychiatrist or psychologist to conduct a clinical interview to make a mental health diagnosis alongside substance misuse. This resulted in a mental health court sample of individuals diagnosed with a range of mental health problems including mood disorder, schizophrenia, bipolar disorder, and dual diagnosis. Other papers referred to use of the DSM-IV diagnostic criteria (Sacks 2011), but subsequently provided little information with regards to individual mental illness needs. Demographic information in the Sacks study reported on other aspects of mental health prognosis, including lifetime mental health treatment, lifetime in patient care, and prescribed medication (Sacks 2004). The Wexler 1999 series of studies reported a range of diagnoses, including antisocial personality disorder, phobias, post-traumatic stress disorder, depression, dysthymia, and attention deficit disorder, but did not describe how these diagnoses were confirmed or assessed within the population.

Six of the eight trials reported on change in mental health wellbeing. Three trials reported on used of the Beck Depression Inventory, Global Severity Index, and the Posttraumatic Diagnostic Scale (Sacks 2004; Sacks 2008; Sacks 2011) Another study reported on depression but used the Hamilton Rating Scale for Depression (Johnson 2012). Two studies reported presence of mood disorder alongside schizophrenia, general anxiety disorder, and antisocial personality disorder (Cosden 2003; Lanza 2013). Future updates of this review will include mental health outcomes in order to assess the impact of treatment on mental health well-being alongside criminality and drug use.

\section{Cost information}

Cost information within the studies was lacking, allowing for little comparison of cost-effectiveness between different types of drug treatment programmes. Regular report of effect sizes would aid calculations for power analysis and provide estimates of the magnitude of treatment effect needed for cost-benefit and cost-effectiveness analysis.

\section{Quality of the evidence}

Overall, the 'Risk of bias' assessment was limited due to lack of information reported in the trials. We therefore rated most of the studies on the majority of 'Risk of bias' measures as unclear. The main limiting factor was the lack of reporting evidence, which prevented the reviewer authors from making a clear judgement of bias. Since the imprecision of reporting lowers the quality of evidence, this means that further research is very likely to have an important impact on our confidence in the estimate of effect and is likely to change the estimate. In addition, a number of specific 
limitations were described relating to the study design (and leading to problems of selection bias), and sample sizes were small. The Stein 2011 study was noted as being relatively underpowered. Replication of the study is required to enhance the generalisation and external validity of the study findings. Similar modest sample sizes were reported by Sacks 2011 and Cosden 2003, who suggested that larger samples should be used to provide a more precise estimate of effect. The Cosden 2003 study also reported on the possibility of outcome bias, as the interviewer was not blind to the outcome condition of the participant, and loss to follow-up (25\% of the study sample were lost to follow-up) at 12 months.

Another possible selection bias concern in the series of Wexler studies was that participants were randomly assigned to the prison therapeutic community treatment and regular prison conditions but not to aftercare (Wexler 1999; Prendergast 2003; Prendergast 2004). The authors noted that possible differences in personal motivation may account for some of the positive outcomes associated with participants' continued support for aftercare services. Subsequently these participants were noted as having the highest 'readiness scores', which suggests that motivation creates an important consideration on client selection (Wexler 1999).

Overall the quality of evidence was judged as moderate for therapeutic community and low to very low for mental health court, motivational interviewing, and interpersonal psychotherapy.

\section{Potential biases in the review process}

Besides the limitations associated with the literature, there are also two limitations of the review methodology. Specifically, the original review included an additional five fee-paying databases and one search using DrugScope. In this current review, resources did not allow such extensive searching. While the electronic database searches were updated to April 2014, the website information has only been updated to November 2011. As a result, the literature will require further extensive searching when the review is next updated.

\section{AUTHORS, CONCLUSIONS}

\section{Implications for practice}

This review highlights the paucity of evidence for drug-using offenders with co-occurring mental illness. Two of the five trials showed some promising results for the use of therapeutic community and aftercare, but only in relation to reducing subsequent reincarceration. Overall, the studies showed a high degree of variation, warranting a degree of caution in the interpretation of the magnitude of effect and direction of benefit for treatment outcomes. More evaluations are required to assess the effectiveness of interventions for drug-using offenders with co-occurring mental illness.

\section{Implications for research}

We have identified several research implications:

1. Good-quality research is required to evaluate the effectiveness of interventions in offenders with substance misuse problems and co-occurring mental illness. Of particular interest is the extended long-term effects of aftercare and the level of contact required with services in the community. Further research to enhance to explore the intensity of different community treatment alternatives following release may help to unravel this process.

2. Better descriptions of participants' mental health problems and more detailed information about mental health diagnoses are required to enable the transferability of information to clinical practice. Such information could also facilitate the use of mental health diagnoses as a moderator within the analysis of the outcomes.

3. Trial interventions specifically focusing on females and adolescents are required. In the current review, only one study contained females, and one study reported on adolescents with depression.

4. Little is known about the interaction between mental illness, individual personal characteristics and positive outcomes relating to treatment success. In terms of depression, Stein 2011 attempted to explore some of the differences between participants with few and with many depressive symptoms. Future studies should consider an analysis of existing datasets which might reveal which individuals with which mental health diagnosis fair better than others. This would reveal who might potentially benefit most from treatment and enable the appropriate targeting of resources.

5. Standardising cost and cost-effectiveness information within trial evaluations would help policymakers make decisions about health versus criminal justice costs. New outcome evaluations should consider the length of time to a parolee's re-arrest or reincarceration, as this has cost implications. For example, the Prendergast 2003/4 study found that community residential treatment kept parolees from relapse or recidivism so long as they remained in treatment topping treatment (prior to the intended dose) tended to lead to relapse or recidivism rates equivalent to participants who received prison treatment only (Prendergast 2003; Prendergast 2004). Such evaluations provide potential important information for stakeholders and funding bodies involved in distributing budgets to fund such enterprises.

\section{ACKNOW LEDGEMENTS}

We would like to acknowledge the help of the York Health Economics Consortium and The Health Sciences Department at the 
University of York and the continued support of the Cochrane

Drugs and Alcohol Group.

\section{R E F E R E N C E S}

\section{References to studies included in this review}

Cosden 2003 \{published data only\}

Cosden M, Ellens JK, Schnell JL, Yamini-Diouf Y, Wolfe MM. Evaluation of a mental health treatment court with assertive community treatment. Behavioral Sciences and the Law 2003;21(4):415-27.

Johnson 2012 \{published data only\}

Johnson JE, Zlotnick C. Pilot study of treatment for major depression among women prisoners with substance use disorder. Journal of Psychiatric Research 2012;46(9): 1174-83. [DOI: 10.1016/j.jpsychires.2012.05.007]

Lanza 2013 \{published data only\}

* Lanza PV, Garcia PF, Lamelas FR, Gonzalez-Menendez A. Acceptance and commitment therapy versus cognitive behavioral therapy in the treatment of substance use disorder with incarcerated women. Journal of Clinical Psychology 2014;70(7):644-57. [DOI: 10.1002/jcip.22060] Lanza PV, Gonzalez-Menendez A. Acceptance and commitment therapy for drug abuse in incarcerated women. Psicothema 2013;25(3):307-12.

Sacks 2004 \{published data only\}

* Sacks S, Sacks JY, McKendrick K, Banks S, Stommel J. Modified TC for MICA inmates in correctional settings: crime outcomes. Behavioural Sciences and the Law 2004;22 (4):477-501.

Sullivan CJ, McKendrick K, Sacks S, Banks S. Modified therapeutic community treatment for offenders with MICA disorders: substance use outcomes. American Journal of Drug and Alcohol Abuse 2007; Vol. 33, issue 6:823-32. [0095-2990: (Print)]

Sacks 2008 \{published data only\}

Sacks JY, McKendrick K, \& Hamilton ZK. A randomized clinical trial of a therapeutic community treatment for female inmates: outcomes at 6 and 12 months after prison release. Journal of Addictive Diseases 2012;31(3):258-69.

* Sacks JY, Sacks S, McKendrick K, Banks S, Schoeneberger M, Hamilton Z, et al. Prison therapeutic community treatment for female offenders: Profiles and preliminary findings for mental health and other variables (crime, substance use and HIV risk). Journal of Offender Rehabilitation 2008;46(3-4):233-61. [: 1050-9674]

Sacks 2011 \{published data only\} Sacks S, Chaple M, Sacks JY, McKendrick K, Cleland CM. Randomized trial of a reentry modified therapeutic community for offenders with co-occurring disorders: crime outcomes. Journal of Substance Abuse Treatment 2011; 23(12):1676-86.
Stein 2011 \{published data only\}

Stein LA, Lebeau R, Colby SM, Barnett NP, Golembeske C, Monti PM. Motivational interviewing for incarcerated adolescents: effects of depressive symptoms on reducing alcohol and marijuana use after release. Journal of Studies on Alcohol and Drugs 2011;72(3):497-506.

\section{Wexler 1999 \{published data only\}}

Prendergast ML, Hall EA, Wexler HK. Multiple measures of outcome in assessing a prison-based drug treatment program. Journal of Offender Rehabilitation 2003;37:65-94. Prendergast ML, Hall EA, Wexler HK, Melnick G, Cao Y. Amity prison-based therapeutic community: 5-year outcomes. Prison Journal 2004;84(1):36-50.

* Wexler HK, DeLeon G, Thomas G, Kressel D, Peters J. The Amity prison TC evaluation - re incarceration outcomes. Criminal Justice and Behavior 1999a;26(2): $147-67$.

Wexler HK, Melnick G, Lowe L, Peters J. Three-year re incarceration outcomes for Amity in-prison therapeutic community and aftercare in California. The Prison Journal 1999b;79(3):321-36.

\section{References to studies excluded from this review}

Alemi 2010 \{published and unpublished data\} Alemi F, Haack M, Nemes S, Harge A, Baghi H. Impact of online counseling on drug use: a pilot study. Quality Management in Health Care 2010;19(1):62-9.

Alessi 2011 \{published data only\} Alessi SM, Rash C, Petry NM. Contingency management is efficacious and improves outcomes in cocaine patients with pretreatment marijuana use. Drug and Alcohol Dependence 2011;118(1):62-7.

Andersson 2014 \{published data only\}

Andersson C, Vasiljevic Z, Hoglund P, Ojehagen A, Berglund M. Daily automated telephone assessment and intervention improved 1-month outcome in paroled offenders. International Journal Offender Therapy Comparative Criminology 2014; online:1-18. [DOI: 10.1177/0306624X14526800]

Anglin 1999 \{published data only\} Anglin MD, Longshore D, Turner S. Treatment alternatives to street crime - an evaluation of five programs. Criminal Justice and Behavior 1999;26(2):168-95.

\section{Awgu 2010 \{published data only\}}

Awgu E, Magura S, Rosenblum A. Heroin-dependent inmates' experiences with buprenorphine or methadone maintenance. Journal of Psychoactive Drugs 2010;42(3): $339-46$. 


\section{Azbel 2013 \{published data only\}}

Azbel L, Wickersham JA, Grishaev Y, Dvoryak S, Altice FL. Burden of infectious diseases, substance use disorders, and mental illness among Ukrainian prisoners transitioning to the community. PLoS ONE 2013;8(3):e59643.

Baldus 2011 \{published data only\}

Baldus C, Miranda A, Weymann N, Reis O, More K, Thomasius R. "CAN Stop" - implementation and evaluation of a secondary group prevention for adolescent and young adult cannabis users in various contexts - study protocol. BMC Health Services Research 2011;11:80.

Baltieri 2014 \{published data only\} Baltieri DA. Order of onset of drug use and criminal activities in a sample of drug-abusing women convicted of violent crimes. Drug \& Alcohol Review 2014;33(2):202-10.

Barnes 2012 \{published data only\}

Barnes GC, Hyatt JM, Ahlman LC, Kent DTL. The effects of low intensity supervision for lower risk probationers: updated results from a RCT. Journal of Crime and Justice 2012;35(2):200-20.

Bayanzadeh 2004 \{published data only\}

Bayanzadeh SA. Final report of research project: A study of the effectiveness of psychopharmacological and psychological interventions in reducing harmful/high risk behaviours among substance user prisoners. Centre for Psychological Health Research Polarity of Science, Education and Research 2004.

Berman 2004 \{published data only\} Berman AH, Lundberg U, Krook AL, Gyllenhammar C. Treating drug using prison inmates with auricular acupuncture: a randomized controlled trial. Journal of Substance Abuse Treatment 2004; Vol. 26, issue 2:95-102.

Black 2011 \{published data only\}

Black S, Carey E, Webber A, Neish N, Gilbert R. Determining the efficacy of auricular acupuncture for reducing anxiety in patients withdrawing from psychoactive drugs. Journal of Substance Abuse Treatment 2011;41(3): 279-87.

Brady 2010 \{published data only\}

Brady LLC, Najavits LM, Toussaint D, Bonavota D, Veysey B. Does recent criminal involvement matter? A study of women with co-occurring disorders in a multisite national trial. Mental Health and Substance Use: Dual Diagnosis 2010;3(3):193-202.

Braithwaite 2005 \{published data only\} Braithwaite RL, Stephens TT, Treadwell HM, Braithwaite K, Conerly R. Short-term impact of an HIV risk reduction intervention for soon-to-be released inmates in Georgia. Journal of Health Care for the Poor and Underserved 2005; Vol. 16, issue 4 Suppl B:130-9. [: CN-00532300]

Breckenridge 2000 \{published data only\} Breckenridge JF, Winfree LT, Maupin JR, Clason DL. Drunk drivers, DWI 'drug court' treatment and recidivism: Who fails?. Justice Research and Policy 2000;2:87-105.
Britt 1992 \{published data only\}

Britt IC, Gottfredson MR, Goldkamp JS. Drug testing and pretrial misconduct: An experiment on the specific deterrent effects of drug monitoring defendants on pretrial release. Journal of Research in Crime and Delinquency 1992; 29(1):62-78.

Brown 2001 \{published data only\}

Brown BS, O'Grady KE, Battjes RJ, Farrell EE, Smith NP, Nurco DN. Effectiveness of a stand-alone aftercare program for drug-involved offenders. Journal of Substance Abuse Treatment 2001;21(4):185-92.

Brown 2013 \{published data only\}

Brown R, Gassman M, Hetzel S, Berger L. Communitybased treatment for opioid dependent offenders: A pilot study. American Journal on Addictions 2013;22(5):500-2.

Burdon 2013 \{published data only\} Burdon WM, St. De Lore J, Dang J, Warda US, Prendergast ML. Psychosocial functioning among inmates in prisonbased drug treatment: Results from Project BRITE. Journal of Experimental Criminology 2013:45-64.

Carr 2008 \{published data only\}

Carr CJ, Xu J, Redko C, Lane D, Rapp RC, Goris J, et al. Individual and system influences on waiting time for substance abuse treatment. Journal of Substance Abuse Treatment 2008; Vol. 34, issue 2:192-201. [: 0740-5472]

Carroll 2006 \{published data only\} Carroll KM, Easton CJ, Nich C, Hunkele KA, Neavins TM, Sinha R, et al. The use of contingency management and motivational/skills-building therapy to treat young adults with marijuana dependence. Journal of Consulting and Clinical Psychology 2006; Vol. 74, issue 5:955-66. [: 0022-006X]

Carroll 2011 \{published data only\} Carroll KM, Kiluk BD, Nich C, Babuscio TA, Brewer JA, Potenza MN, et al. Cognitive function and treatment response in a randomized clinical trial of computer-based training in cognitive-behavioral therapy. Substance Use \& Misuse 2011;46(1):23-34.

Carroll 2012 \{published data only\} Carroll KM, Nich C, Lapaglia DM, Peters EN, Easton CJ, Petry NM. Combining cognitive behavioral therapy and contingency management to enhance their effects in treating cannabis dependence: less can be more, more or less. Addiction 2012;107(9):1650-9.

Chandler 2006 \{published data only\} Chandler DW, Spicer G. Integrated treatment for jail recidivists with co-occurring psychiatric and substance use disorders. Community Mental Health Journal 2006; Vol. 42, issue 4:405-25.

Chaple 2014 \{published data only\} Chaple M, Sacks S, McKendrick K, Marsch LA, Belenko $S$, Leukefeld C, et al. Feasibility of a computerized intervention for offenders with substance use disorders: a research note. Journal of Experimental Criminology 2014;10: 105-27. 
Clair 2013 \{published data only\}

Clair M, Stein LA, Soenksen S, Martin RA, Lebeau R, Golembeske C. Ethnicity as a moderator of motivational interviewing for incarcerated adolescents after release. Journal of Substance Abuse Treatment 2013;45(4):370-5.

Cogswell 2011 \{published data only\}

Cogswell J, Negley SK. The effect of autonomy-supportive therapeutic recreation programming on integrated motivation for treatment among persons who abuse substances. Therapeutic Recreation Journal 2011;45(1):1st Quarter: 47-61.

Cornish 1997 \{published data only\}

* Cornish JW, Metzger D, Woody GE, Wilson D, McLellan AT, Vandergrift B, et al. Naltrexone pharmacotherapy for opioid dependent federal probationers. Journal of Substance Abuse Treatment 1997;14(6):529-34.

Cosden 2003a \{published data only\}

Cosden M, Ellens JK, Schnell JL, Yamini-Diouf Y, Wolfe MM. Evaluation of a mental health treatment court with assertive community treatment. Behavioral Sciences \& the Law 2003;21(4):415-27.

Cosden 2005 \{published data only\}

Cosden M, Ellens J, Schnell J, Yamini-Diouf Y. Efficacy of a mental health treatment court with assertive community treatment. Behavior Sciences and the Law 2005; Vol. 23, issue 2:199-214. [0735-3936: (Print)]

Coviello 2010 \{published data only\}

Coviello DM, Cornish JW, Lynch KG, Alterman AI, O'Brien CP. A randomized trial of oral naltrexone for treating opioid-dependent offenders. American Journal on Addiction 2010;19(5):422-32.

Coviello 2012 \{published data only\}

Coviello DM, Cornish JW, Lynch KG, Boney TY, Clark CA, Lee JD, et al. A multisite pilot study of extendedrelease injectable naltrexone treatment for previously opioiddependent parolees and probationers. Substance Abuse 2012; 33(1):48-59. [DOI: 10.1080/08897077.2011.609438]

Cox 2013 \{published data only\}

Cox BR, Olney JJ, Lowery-Gionta EG, Sprow GM, Rinker JA, Navarro M, et al. Repeated cycles of bingelike ethanol $(\mathrm{EtOH})$-drinking in male $\mathrm{C} 57 \mathrm{BL} / 6 \mathrm{~J}$ mice augments subsequent voluntary $\mathrm{EtOH}$ intake but not other dependence-like phenotypes. Alcoholism, Clinical and Experimental Research 2013;37(10):1688-95.

Cropsey 2011 \{published data only\} Cropsey KL, Lane PS, Hale GJ, Jackson DO, Clark CB, Ingersoll KS, et al. Results of a pilot randomized controlled trial of buprenorphine for opioid dependent women in the criminal justice system. Drug and Alcohol Dependence 2011; 119(3):172-8.

Cropsey 2013 \{published data only\}

Cropsey KL, Lane PS, Perkins AC, Clark CB, Hardy $\mathrm{S}$, McCullumsmith $\mathrm{C}$, et al. Buprenorphine and medication management in a community corrections population: A pilot study. Journal of Addiction Medicine
2013;7(3):210-5. [DOI: http://dx.doi.org/10.1097/

ADM.0b013e31828e6b21]

Cullen 2011 \{published data only\}

Cullen AE, Soria C, Clarke AY, Dean K, Fahy T. Factors predicting dropout from the reasoning and rehabilitation program with mentally disordered offenders. Criminal Justice and Behavior 2011;38(3):217-30. [DOI: 10.1177/ 0093854810393659]

Cusack 2010 \{published data only\} Cusack K J, Morrissey J P, Cuddeback G S, Prins A, Williams D M. Criminal justice involvement, behavioral health service use, and costs of forensic assertive community treatment: a randomized trial. Community Mental Health Journal 2010;46(4):356-63.

D’Amico 2013 \{published data only\} D'Amico EJ, Hunter SB, Miles JN, Ewing BA, Osilla KC. A randomized controlled trial of a group motivational interviewing intervention for adolescents with a first time alcohol or drug offence. Journal of Substance Abuse Treatment 2013;45(5):400-8.

Dakof 2010 \{published data only\}

Dakof G A, Cohen J B, Henderson C E, Duarte E, Boustani M, Blackburn A, et al. A randomized pilot study of the Engaging Moms Program for family drug court. Journal of Substance Abuse Treatment 2010;38(3):263-74.

Dana 2013 \{published data only\}

Dana D, Zary N, Peyman A, Behrooz A. Risk prison and hepatitis $B$ virus infection among inmates with history of drug injection in Isfahan, Iran. Scientific World Journal 2013;735761:1-4.

DeFulio 2013 \{published data only\} DeFulio A, Stitzer M, Roll J, Petry N, Nuzzo P, Schwartz RP, et al. Criminal justice referral and incentives in outpatient substance abuse treatment. Journal of Substance Abuse Treatment 2013;45(1):70-5. [DOI: http://dx.doi.org/ $10.1016 /$ j.jsat.2012.12.012]

Dembo 2000 \{published data only\} Dembo R, Ramirez GG, Rollie M, Schmeidler J, Livingston $S$, Hartsfield A. Youth recidivism twelve months after a family empowerment intervention: final report. Journal of Offender Rehabilitation 2000;31(3/4):29-65.

Deschenes 1994 \{published data only\} Deschenes EP, Greenwood PW. Maricopa-County Drug Court - an innovative program for 1st-time drug offenders on probation. Justice System Journal 1994;17(1):99-115.

\section{Diamond 2006 \{published data only\}}

Diamond G, Panichelli-Mindel SM, Shrea D, Dennis M, Tims F, Ungemack J. Psychiatric syndromes in adolescents with marijuana abuse and dependency in outpatient treatment. Journal of Child \& Adolescent Substance Abuse 2006; Vol. 15, issue 4:37-54.

Di Nitto 2002 \{published data only\}

Di Nitto DM, Webb DK, Rubin A. The effectiveness of an integrated treatment approach for clients with dual diagnoses. Research on Social Work Practice 2002;12(5): $621-41$. 
Dolan 2003 \{published data only\}

Dolan KA, Shearer J, MacDonald M, Mattick RP, Hall W, Wodak AD. A randomised controlled trial of methadone maintenance treatment versus wait list control in an Australian prison system. Drug and Alcohol Dependence 2003;72(1):59-65.

Dole 1969 \{published data only\}

Dole VP, Robinson MD, Orraca J, Towns E, Searcy P, Caine E. Methadone treatment of randomly selected criminal addicts. The New England Journal of Medicine 1969;280: $1372-5$.

Dugan 1998 \{published data only\}

Dugan JR, Everett RS. An experimental test of chemical dependency therapy for jail inmates. International Journal of Offender Therapy \& Comparative Criminology 1998;42(4): $360-8$.

Evans 2012 \{published data only\} Evans E, Jaffe A, Urada D, Anglin MD. Differential outcomes of court-supervised substance abuse treatment among California parolees and probationers. International Journal of Offender Therapy and Comparative Criminology 2012;56(4):539-56.

Forsberg 2011 \{published data only\}

Forsberg LG, Ernst D, Sundqvist K, Farbring CA. Motivational Interviewing delivered by existing prison staff: a randomized controlled study of effectiveness on substance use after release. Substance Use \& Misuse 2011;46(12): 1477-85.

Freudenberg 2010 \{published data only\}

Freudenberg N, Ramaswamy M, Daniels J, Crum M, Ompad DC, Vlahov D. Reducing drug use, human immunodeficiency virus risk, and recidivism among young men leaving jail: evaluation of the REAL MEN re-entry program. Journal of Adolescent Health 2010;47(5):448-55.

Friedman 2012 \{published data only\}

Friedman SR, West BS, Pouget ER, Hall HI, Cantrell J, Tempalski B, et al. Metropolitan social environments and pre-HAART/HAART era changes in mortality rates (per 10, 000 adult residents) among injection drug users living with AIDS. PLoS ONE 2013;8(2):12. [DOI: e5720110.1371/ journal.pone.0057201]

Frost 2013 \{published data only\}

Frost M, Iacobacci B. Utilization of buprenorphine assisted opioid dependence treatment in a county drug court program. Journal of Addiction Medicine 2013;7(4):E10.

Gagnon 2010 \{published data only\}

Gagnon H, Godin G, Alary M, Bruneau J, Otis J. A randomized trial to evaluate the efficacy of a computertailored intervention to promote safer injection practices among drug users. AIDS \& Behavior 2010;14(3):538-48.

Gil 2004 \{published data only\}

Gil AG, Wagner EF, Tubman JG. Culturally sensitive substance abuse intervention for Hispanic and African American adolescents: empirical examples from the Alcohol Treatment Targeting Adolescents in Need (ATTAIN)
Project. Addiction 2004; Vol. 99, issue Suppl 2:140-50. [: 0965-2140]

Gordon 2012 \{published data only\}

Gordon M, Kinlock TW, Couvillion KA, Schwartz RP, O'Grady K. A randomized clinical trial of methadone maintenance for prisoners: prediction of treatment entry and completion in prison. Journal of Offender Rehabilitation 2012;51(4):222-38.

Gordon 2013 \{published data only\} Gordon MS, Kinlock TW, Couvillion KA, Wilson ME, Schwartz RP, O'Grady KE. Gender differences among prisoners with pre-incarceration heroin dependence participating in a randomized clinical trial of buprenorphine treatment. Journal of Offender Rehabilitation 2013;52(5): 376-91.

Gottfredson 2002 \{published data only\}

Gottfredson DC, Exum ML. The Baltimore City drug treatment court: one-year results from a randomized study. Journal of Research in Crime and Delinquency 2002;39(3): $337-56$.

Grohman 2004 \{published data only\} Grohman K, Fals-Stewart W. The detection of cognitive impairment among substance-abusing patients: the accuracy of the neuropsychological assessment battery-screening module. Experimental and Clinical Psychopharmacology 2004; Vol. 12, issue 3:200-207.

Grommon 2013a \{published data only\} Grommon E, Cox SM, Davidson WS, Bynum TS. Alternative models of instant drug testing: Evidence from an experimental trial. Journal of Experimental Criminology 2013;9(2):145-68. [DOI: http://dx.doi.org/10.1007/ s11292-012-9168-6]

Grommon 2013b \{published data only\} Grommon E, Davidson II WS, Bynum TS. A randomized trial of a multimodal community-based prisoner reentry program emphasizing substance abuse treatment. Journal of Offender Rehabilitation 2013;52(4):287-309. [DOI: http:// dx.doi.org/10.1080/10509674.2013.782775]

Guydish 2011 \{published data only\} Guydish J, Chan M, Bostrom A, Jessup M, Davis T, Marsh C. A randomized trial of probation case management for drug-involved women offenders. Crime and Delinquency 2011;57(2):167-98.

Guydish 2014 \{published data only\}

Guydish J, Campbell BK, Manuel JK, Delucchi KL, Le T, Peavy KM, et al. Does treatment fidelity predict client outcomes in 12-Step Facilitation for stimulant abuse?. Drug \& Alcohol Dependence 2014;134:330-6.

Haapanen 2002 \{published data only\}

* Haapanen R, Britton L. Drug testing for youthful offenders on parole: an experimental evaluation. Criminology and Public Policy 2002;1(2):217-44.

Haasen 2010 \{published data only\}

Haasen C, Verthein U, Eiroa-Orosa F J, Schäfer I, Reimer J. Is heroin-assisted treatment effective for patients with no 
previous maintenance treatment? Results from a German randomised controlled trial. European Addiction Research 2010;16(3):124-30.

Hanlon 1999 \{published data only\}

* Hanlon TE, Bateman RW, O'Grady KE. The relative effects of three approaches to the parole supervision of narcotic addicts and cocaine abusers. Prison Journal 1999; 79(2):163-81.

Harada 2012 \{published data only\} Harada T. The randomized controlled trial of the prison-based Japanese Matrix Program (J-MAT) for methamphetamine abusers. Japanese Journal of Alcohol Studies \& Drug Dependence 2012;47(6):298-307.

Harrell 2001 \{published data only\} Harrell A, Roman J. Reducing drug use and crime among offenders: the impact of graduated sanctions. Journal of Drug Issues 2001;31(1):207-32.

Henderson 2010 \{published data only\} Henderson CE, Dakof GA, Greenbaum PE, Liddle HA. Effectiveness of multidimensional family therapy with higher severity substance-abusing adolescents: report from two randomized controlled trials. Journal of Consulting and Clinical Psychology 2010;78(6):885-97.

Henggeler 1991 \{published data only\}

Henggeler SW, Borduin CM, Melton GB, Mann BJ. Effects of multisystemic therapy on drug use and abuse in serious juvenile offenders: a progress report from two outcome studies. Family Dynamics of Addiction Quarterly 1991;1(3): 40-51.

Henggeler 1999 \{published data only\}

* Henggeler SW, Pickrel SG, Brondino MJ. Multisystemic treatment of substance-abusing and dependent delinquents: outcomes, treatment fidelity, and transportability. Mental Health Services Research 1999;1(3):171-84.

Henggeler 2002 \{published data only\} Henggeler SW, Clingempeel WG, Brondino MJ, Pickrel SG. Four-year follow-up of multisystemic therapy with substance-abusing and substance-dependent juvenile offenders. Journal of the American Academy of Child \& Adolescent Psychiatry 2002;41(7):868-74.

Henggeler 2006 \{published data only\}

Henggeler SW, Halliday-Boykins CA, Cunningham PB, Randall J, Shapiro SB, Chapman JE. Juvenile drug court: enhancing outcomes by integrating evidence-based treatments. Journal of Consulting and Clinical Psychology 2006;74(1):42-54. [0022-006X: (Print)]

Henggeler 2012 \{published data only\}

Henggeler SW, McCart MR, Cunningham PB, Chapman JE. Enhancing the effectiveness of juvenile drug courts by integrating evidence-based practices. Journal of Consulting \& Clinical Psychology 2012;80(2):264-75. [DOI: 10.1037/ a0027147]

Howells 2002 \{published data only\}

Howells C, Allen S, Gupta J, Stillwell G, Marsden J, Farrell M. Prison based detoxification for opioid dependence: a randomised double blind controlled trial of lofexidine and methadone. Drug \& Alcohol Dependence 2002;67(2): 169-76.

\section{Hser 2011 \{published data only\}}

Hser Y-I, Li J, Jiang H, Zhang R, Du J, Zhang C, et al. Effects of a randomized contingency management intervention on opiate abstinence and retention in methadone maintenance treatment in China. Addiction 2011;106(10):1801-9.

Hser 2013 \{published data only\} Hser YI, Fu L, Wu F, Du J, Zhao M. Pilot trial of a recovery management intervention for heroin addicts released from compulsory rehabilitation in China. Journal of Substance Abuse Treatment 2013;44(1):78-83. [DOI: http://dx.doi.org/10.1016/j.jsat.2012.03.009]

\section{Inciardi 2004 \{published data only\}}

Inciardi JA, Martin SS, Butzin CA. Five-year outcomes of therapeutic community treatment of drug-involved offenders after release from prison. Crime \& Delinquency 2004; Vol. 50, issue 1:88-107. [: 0011-1287]

Jain 2011 \{published data only\}

Jain K, Jain R, Dhawan A. A double-blind, doubledummy, randomized controlled study of memantine versus buprenorphine in naloxone-precipitated acute withdrawal in heroin addicts. Journal of Opioid Management 2011;7(1): 11-20.

Johnson 2011 \{published data only\} Johnson JE, Friedmann PD, Green TC, Harrington M, Taxman FS. Gender and treatment response in substance use treatment-mandated parolees. Journal of Substance Abuse Treatment 2011;40(3):313-21.

Jones 2011 \{published data only\} Jones RK. Evaluation of the DUI court program in Maricopa County, Arizona. Washington, DC: U.S. Department of Transportation 2011.

\section{Jones 2013 \{published data only\}}

Jones CG. Early-phase outcomes from a randomized trial of intensive judicial supervision in an Australian Drug Court. Criminal Justice and Behavior 2013;40(4):453-68. [DOI: http://dx.doi.org/10.1177/0093854812449215]

Katz 2007 \{published data only\}

Katz EC, Brown BS, Schwartz RP, King SD, Weintraub E, Barksdale W. Impact of role induction on long-term drug treatment outcomes. Journal of Addictive Diseases 2007; Vol. 26, issue 2:81-90. [: CN-00590052]

Kelly 2013 \{published data only\} Kelly SM, O’Grady KE, Jaffe JH, Gandhi D, Schwartz RP. Improvements in outcomes in methadone patients on probation/parole regardless of counseling early in treatment. Journal of Addiction Medicine 2013;7(2):133-8. [DOI: http://dx.doi.org/10.1097/ADM.0b013e318284a0c1]

Kidorf 2013 \{published data only\} Kidorf M, Brooner RK, Gandotra N, Antoine D, King VL, Peirce J, et al. Reinforcing integrated psychiatric service attendance in an opioid-agonist program: a randomized 
and controlled trial. Drug \& Alcohol Dependence 2013;133 (1):30-6.

King 2014 \{published data only\}

King VL, Brooner RK, Peirce JM, Kolodner K, Kidorf MS. A randomized trial of Web-based videoconferencing for substance abuse counseling. Journal of Substance Abuse Treatment 2014;46(1):36-42.

Kinlock 2005 \{published data only\}

Kinlock TW, Battjes RJ, Schwartz RP, MTC Project Team. A novel opioid maintenance program for prisoners: report of post-release outcomes. American Journal of Drug and Alcohol Abuse 2005; Vol. 31, issue 3:433-54. [: $\mathrm{CN}-00590052$ ]

Kinlock 2007 \{published data only\}

Kinlock TW, Gordon MS, Schwartz RP, O'Grady K, Fitzgerald TT, Wilson M. A randomized clinical trial of methadone maintenance for prisoners: results at 1-month post-release. Drug and Alcohol Dependence 2007; Vol. 91, issue 2-3:220-7. [: 0376-8716]

Kinlock 2008 \{published data only\} Kinlock TW, Gordon MS, Schwartz RP, O'Grady KE. A study of methadone maintenance for male prisoners: 3month postrelease outcomes. Criminal Justice and Behavior 2008; Vol. 35, issue 1:34-47. [0093-8548: (Print)]

Kinlock 2009 \{published data only\}

Kinlock T, Gordon M, Schwartz R. Buprenorphine for prisoners: preliminary findings at one-month post release. Conference Papers - American Society of Criminology. 2009:1.

Kinlock 2009b \{published data only\}

Kinlock TW, Gordon MS, Schwartz RP, Fitzgerald TT, O'Grady KE. A randomized clinical trial of methadone maintenance for prisoners: Results at 12 months postrelease. Journal of Substance Abuse Treatment 2009; Vol. 37, issue 3:277-85. [: 0740-5472]

Kok 2013 \{published data only\}

Kok T, de Haan HA, van der Meer M, Najavits LM, DeJong CA.J. Efficacy of "seeking safety" in a Dutch population of traumatized substance-use disorder outpatients: study protocol of a randomized controlled trial. $B M C$ Psychiatry 2013;13(8):162-70. [DOI: 16210.1186/ 1471-244x-13-162]

Law 2012 \{published data only\} Law FM, Guo GJ. Hope and recovery from substance abuse for female drug offenders in Taiwan. International Journal of Offender Therapy and Comparative Criminology 2012;56 (8):1258-82.

Lee 2012 \{published data only\}

Lee JD, Grossman E, Truncali A, Rotrosen J, Rosenblum A, Magura S, et al. Buprenorphine-naloxone maintenance following release from jail. Substance Abuse 2012;33(1): 40-7. [DOI: 10.1080/08897077.2011.620475]

Liddle 2011 \{published data only\} Liddle H A, Dakof G A, Henderson C, Rowe C. Implementation outcomes of multidimensional family therapy-detention to community: a reintegration program for drug-using juvenile detainees. International Journal of Offender Therapy Comparative Criminology 2011;55(4): 587-604.

Ling 2013 \{published data only\}

Ling Murtaugh K, Krishnamurti T, Davis AL, Reback CJ, Shoptaw S. Spend today, clean tomorrow: predicting methamphetamine abstinence in a randomized controlled trial. Health Psychology 2013;32(9):958-66.

Lobmaier 2010 \{published data only\} Lobmaier PP, Kunoe N, Gossop M, Katevoll T, Waal H. Naltrexone implants compared to methadone: outcomes six months after prison release. European Addiction Research 2010;16(3):139-45.

Lobmann 2007 \{published data only\} Lobmann R. Diamorphine substitution therapy and criminal activity. Sucht: Zeitschrift fur Wissenschaft und Praxis 2007; Vol. 53, issue 5:288-95. [: CN-00627424]

Lobmann 2009 \{published data only\} Lobmann R, Verthein U. Explaining the effectiveness of heroin-assisted treatment on crime reductions. Law and Human Behavior 2009;33(1):83-95. [DOI: $10.1007 /$ s10979-008-9138-8]

MacDonald 2007 \{published data only\} MacDonald JM, Morral AR, Raymond B, Eibner C. The efficacy of the Rio Hondo DUI court: A 2-year field experiment. Evaluation Review 2007;31(4):4-23.

Magura 2009 \{published data only\} Magura S, Lee JD, Hershberger J, Joseph H, Marsch L, Shropshire C, et al. Buprenorphine and methadone maintenance in jail and post-release: a randomized clinical trial. Drug and Alcohol Dependence 2009; Vol. 99, issue $1-3: 222-30$.

Marlowe 2003 \{published data only\} Marlowe DB, Festinger DS, Lee PA, Schepise MM, Hazzard JER, Merrill JC, et al. Are judicial status hearings a key component of drug court? During-treatment data from a randomized trial. Criminal Justice and Behavior 30;2: $141-62$.

Marlowe 2005 \{published data only\} Marlowe DB, Festinger DS, Dugosh KL, Lee PA. Are judicial status hearings a "key component" of drug court? Six and twelve month outcomes. Drug and Alcohol Dependence 79;2:145-55.

Marlowe 2007 \{published data only\} Marlowe DB, Festinger DS, Dugosh KL, Lee PA, Benasutti KM. Adapting judicial supervision to the risk level of drug offenders: discharge and 6-month outcomes from a prospective matching study. Drug and Alcohol Dependence 2007;88(Suppl 2):S4-S13.

Marlowe 2008 \{published data only\} Marlowe DB, Festinger DS, Dugosh KL, Arabia PL, Kirby $\mathrm{KC}$. An effectiveness trial of contingency management in a felony preadjudication drug court. Journal of Applied Behavior Analysis 2008; Vol. 41, issue 4:565-77. 
Marsch 2014 \{published data only\}

Marsch LA, Guarino H, Acosta M, Aponte-Melendez Y, Cleland C, Grabinski M, et al. Web-based behavioral treatment for substance use disorders as a partial replacement of standard methadone maintenance treatment. Journal of Substance Abuse Treatment 2014;46(1):43-51.

Martin 1993 \{published data only\}

Martin SS, Scarpitti SR. An intensive case management approach for paroled IV drug users. Journal of Drug Issues 1993;23(1):43-59.

\section{Mbilinyi 2011 \{published data only\}}

Mbilinyi LF, Neighbors C, Walker DD, Roffman RA, Zegree J, Edleson J, et al. A telephone intervention for substance-using adult male perpetrators of intimate partner violence. Research on Social Work Practice 2011;21(1): 43-56.

\section{McKendrick 2007 \{published data only\}}

McKendrick K, Sullivan C, Banks S, Sacks S. Modified therapeutic community treatment for offenders with MICA disorders: antisocial personality disorder and treatment outcomes. Journal of Offender Rehabilitation 2006; Vol. 44, issue 2-3:133-59. [: 1050-9674]

McKenzie 2012 \{published data only\} McKenzie M, Zaller N, Dickman SL, Green TC, Parihk A, Friedmann PD, et al. A randomized trial of methadone initiation prior to release from incarceration. Substance Abuse 2012;33(1):19-29. [DOI: 10.1080/ 08897077.2011.609446]

Messina 2000 \{published data only\} Messina N, Wish E, Nemes S. Predictors of treatment outcomes in men and women admitted to a therapeutic community. American Journal of Drug \& Alcohol Abuse 2000;26(2):207-27.

Milloy 2011 \{published data only\} Milloy MJS, Kerr T, Zhang R, Tyndall M, Montaner J. Randomised Trial of the Effectiveness of Naloxone. London: Department of Health, 2011.

Needels 2005 \{published data only\} Needels K, James-Burdumy S, Burghardt J. Community case management for former jail inmates: its impacts on rearrest, drug use, and HIV risk. Journal of Urban Health 2005; Vol. 82, issue 3:420-33. [1099-3460: (Print)]

\section{Nemes 1998 \{published data only\}}

Nemes S, Wish E, Messina N. The District of Columbia Treatment Initiative (DCI) final report. College Park, MD: University of Maryland, National Evaluation Data and Technical Assistance Center (NEDTAC), 1998.

Nemes 1999 \{published data only\}

Nemes S, Wish ED, Messina N. Comparing the impact of standard and abbreviated treatment in a therapeutic community: Findings from the District of Columbia treatment initiative experiment. Journal of Substance Abuse Treatment 1999;17(4):339-47.
Nielsen 1996 \{published data only\}

Farrell A. Women, crime and drugs: testing the effect of therapeutic communities. Women and Criminal Justice 2000;11(1):21-48.

* Nielsen AL, Scarpitti FR, Inciardi JA. Integrating the therapeutic community and work release for drug-involved offenders: The CREST Program. Journal of Substance Abuse Treatment 1996;13(4):349-58.

Nosyk 2010 \{published data only\}

Nosyk B, Geller J, Guh DP, Oviedo-Joekes E, Brissette $S$, Marsh DC, et al. The effect of motivational status on treatment outcome in the North American Opiate Medication Initiative (NAOMI) study. Drug and Alcohol Dependence 2010;111(1-2):161-5.

\section{Petersilia 1992 \{published data only\}}

Petersilia J, Turner S, Deschenes EP. Intensive supervision programs for drug offenders. In: Byrne JM, Lurigio AJ editor(s). Smart Sentencing: The Emergence of Intermediate Sanctions. Thousand Oaks, CA: Sage Publications Inc, 1992:18-37.

\section{Petry 2005 \{published data only\}}

Petry NM, Peirce JM, Stitzer ML, Blaine J, Roll JM, Cohen A, et al. Effect of prize-based incentives on outcomes in stimulant abusers in outpatient psychosocial treatment programs: a national drug abuse treatment clinical trials network study. Archives of General Psychiatry 2005;62(10): 1148-56. [DOI: 10.1001/archpsyc.62.10.1148]

Petry 2011 \{published data only\} Petry NM, Ford JD, Barry D. Contingency management is especially efficacious in engendering long durations of abstinence in patients with sexual abuse histories. Psychology of Addictive Behaviour 2011;25(2):293-300.

Polsky 2010 \{published data only\}

Polsky D, Glick HA, Yang J, Subramaniam GA, Poole SA, Woody GE. Cost-effectiveness of extended buprenorphinenaloxone treatment for opioid-dependent youth: data from a randomized trial. Addiction 2010;105(9):1616-24.

Prendergast 2008 \{published data only\}

Prendergast ML, Hall EA, Roll J, Warda U. Use of vouchers to reinforce abstinence and positive behaviors among clients in a drug court treatment program. Journal of Substance Abuse Treatment 2008;35(2):125-36. [1873-6483: (Electronic)]

Prendergast 2009 \{published data only\} Prendergast M, Greenwell L, Cartier J, Sacks J, Frisman $\mathrm{L}$, Rodis E, et al. Adherence to scheduled sessions in a randomized field trial of case management: the Criminal Justice-Drug Abuse Treatment Studies Transitional Case Management Study. Journal of Experimental Criminology 2009;5(3):273-97.

Prendergast 2011 \{published data only\} Prendergast M, Frisman L, Sacks JY, Staton-Tindall M, Greenwell L, Lin HJ, et al. A multi-site, randomized study of strengths-based case management with substance-abusing parolees. Journal of Experimental Criminology 2011;7(3): $225-53$. 
Proctor 2012 \{published data only\}

Proctor SL, Hoffmann NG, Allison S. The effectiveness of interactive journaling in reducing recidivism among substance-dependent jail inmates. International Journal of Offender Therapy and Comparative Criminology 2012;56(2): 317-32.

Reimer 2011 \{published data only\} Reimer J, Verthein U, Karow A, Schäfer I, Naber D, Haasen C. Physical and mental health in severe opioid-dependent patients within a randomized controlled maintenance treatment trial. Addiction 2011;106(9):1647-55.

Robertson 2006 \{published data only\} Robertson JR, Raab GM, Bruce M, McKenzie JS, Storkey HR, Salter A. Addressing the efficacy of dihydrocodeine versus methadone as an alternative maintenance treatment for opiate dependence: a randomized controlled trial. Addiction (Abingdon, England) 2006; Vol. 101, issue 12: 1752-9. [: CN-00577209]

Rosengard 2008 \{published data only\} Rosengard C, Stein LAR, Barnett NP, Monti PM, Golembeske C, Lebeau-Craven R, et al. Randomized clinical trial of motivational enhancement of substance use treatment among incarcerated adolescents. Journal of HIVI AIDS Prevention in Children and Youth 2008;8(2):45-64.

Rossman 1999 \{published data only\}

* Rossman S, Sridharan S, Gouvis C, Buck J, Morley E. Impact of the Opportunity to Succeed (OPTS) Aftercare Program for Substance-Abusing Felons: Comprehensive Final Report. Washington, DC: Urban Institute, 1999.

Rounsaville 2001 \{published data only\}

Rounsaville BJ, Carroll KM, Onken LS. A stage model of behavioral therapies research: Getting started and moving on from stage I. Clinical Psychology-Science and Practice 2001;8(2):133-42. [DOI: 10.1093/clipsy/8.2.133]

Rowan-Szal 2005 \{published data only\} Rowan-Szal GA, Bartholomew NG, Chatham LR, Simpson DD. A combined cognitive and behavioral intervention for cocaine-using methadone clients. Journal of Psychoactive Drugs 2005;37(1):75-84.

Rowan-Szal 2009 \{published data only\} Rowan-Szal GA, Joe GW, Simpson D, Greener JM, Vance J. During-treatment outcomes among female methamphetamine-using offenders in prison-based treatments. Journal of Offender Rehabilitation 2009;48(5): 388-401.

Rowe 2007 \{published data only\}

Rowe M, Bellamy C, Baranoski M, Wieland M, Connell $\mathrm{MJO}$, Benedict $\mathrm{P}$, et al. A peer-support, group intervention to reduce substance use and criminality among persons with severe mental illness. Psychiatric Services 2007; Vol. 58, issue 7:955-61. [: 1075-2730]

Sanchez-Hervas 2010 \{published data only\} Sanchez-Hervas E, Secades-Villa R, Romaguera FZ, Fernandez GG, Gomez FJS, Garcia-Rodriguez O. Behavioral therapy for cocaine addicts: outcomes of a follow-up six month study. Revista Mexicana De Psicologia 2010;27(2):159-67.

Schaeffer 2014 \{published data only\}

Schaeffer CM, Henggeler SW, Ford JD, Mann M, Chang R, Chapman JE. RCT of a promising vocational/employment program for high-risk juvenile offenders. Journal of Substance Abuse Treatment 2014;46(2):134-43. [DOI: http: //dx.doi.org/10.1016/j.jsat.2013.06.012]

Schmiege 2009 \{published data only\}

Schmiege SJ, Broaddus MR, Levin M, Bryan AD.

Randomized trial of group interventions to reduce HIV/ STD risk and change theoretical mediators among detained adolescents. Journal of Consulting and Clinical Psychology 2009;77(1):38-50. [DOI: 10.1037/A0014513]

Schwartz 2006 \{published data only\} Schwartz RP, Highfield DA, Jaffe JH, Brady JV, Butler CB, Rouse $\mathrm{CO}$, et al. A randomized controlled trial of interim methadone maintenance. Archives of General Psychiatry 2006;63(1):102-9.

Shanahan 2004 \{published data only\}

Shanahan M, Lancsar E, Haas M, Lind B, Weatherburn D, Chen S. Cost-effectiveness analysis of the New South Wales adult drug court program. Evaluation Review 2004;28(1): 3-27.

Sheard 2009 \{published data only\}

Sheard L, Wright NM, El-Sayeh CE, Adams C, Li R, Tompkins CN. The Leeds Evaluation of Efficacy of Detoxification Study (LEEDS) prisons project: a randomised controlled trial comparing dihydrocodeine and buprenorphine for opiate detoxification. Substance Abuse Treatment Prevention and Policy 2009;4:1.

Siegal 1999 \{published data only\} Siegal HA, Jichuan W, Carlson RG, Falck RS, Rahman AM, Fine RL. Ohio's prison-based therapeutic community treatment programs for substance abusers: preliminary analysis of re-arrest data. Journal of Offender Rehabilitation 1999;28(3/4):33-48.

Sinha 2003 \{published data only\}

Sinha R, Easton C, Renee-Aubin L, Carroll KM. Engaging young probation-referred marijuana-abusing individuals in treatment: a pilot trial. American Journal on Addictions 2003;12(4):314-23.

Smith 2010 \{published data only\}

Smith DK, Chamberlain P, Eddy JM. Preliminary support form multidimensional treatment foster care in reducing substance use in delinquent boys. Journal of Child \& Adolescent Substance Abuse 2010;19:343-58.

Solomon 1995 \{published data only\}

Solomon P, Draine J. One-year outcomes of a randomized trial of case-management with seriously mentally-Ill clients leaving jail. Evaluation Review 1995;19(3):256-73. [DOI: 10.1177/0193841×9501900302]

Specka 2013 \{published data only\} Specka M, Boning A, Kluwig J, Schifano F, Banger M, Lange W, et al. Can reinforcement-based interventions to 
reduce drug use successfully be adapted to routine opioid maintenance treatment?. Annali dell Istituto Superiore di Sanita 2013;49(4):358-64.

Stanger 2009 \{published data only\}

Stanger C, Budney AJ, Kamon JL, Thostensen J. A randomized trial of contingency management for adolescent marijuana abuse and dependence. Drug and Alcohol Dependence 2009; Vol. 105, issue 3:240-7. [: 0376-8716]

Staton-Tindall 2009 \{published data only\}

Staton-Tindall M, McNees E, Leukefeld CG, Walker R, Thompson L, Pangburn K, et al. Systematic outcomes research for corrections-based treatment: implications from the criminal justice Kentucky treatment outcome study. Journal of Offender Rehabilitation 2009;48(8):710-24.

Stein 2006 \{published data only\}

Stein LA, Monti PM, Colby SM, Barnett NP, Golembeske $\mathrm{C}$, Lebeau-Craven R, et al. Enhancing substance abuse treatment engagement in incarcerated adolescents. Psychological Services 2006;3(1):25-34.

Stein 2010 \{published data only\}

Stein MD, Herman DS, Kettavong M, Cioe PA, Friedmann PD, Tellioglu T, et al. Antidepressant treatment does not improve buprenorphine retention among opioid-dependent persons. Journal of Substance Abuse Treatment 2010;39(2): 157-66.

Stevens 1998 \{published data only\} Stevens SJ, Patton T. Residential treatment for drug addicted women and their children: effective treatment strategies. Drugs \& Society 1998;13(1-2):235-49.

Svikis 2011 \{published data only\} Svikis DS, Keyser-Marcus L, Stitzer M, Rieckmann T, Safford L, Loeb P, et al. Randomized multi-site trial of the Job Seekers' Workshop in patients with substance use disorders. Drug and Alcohol Dependence 2012;120(1-3): $55-64$.

Taxman 2006/Thanner 2003 \{published data only\} Taxman FS, Meridith T. Risk, need, and responsivity (RNR): it all depends. Crime \& Delinquency 2006; Vol. 52, issue 1:28-51. [0095-2990: (Print)]

Vagenas 2014 \{published data only\} Vagenas P, Di Paola A, Herme M, Lincoln T, Skiest DJ, Altice FL, et al. An evaluation of hepatic enzyme elevations among HIV-infected released prisoners enrolled in two randomized placebo-controlled trials of extended release naltrexone. Journal of Substance Abuse Treatment 2014;47 (1):35-40

Vanderberg 2002 \{published data only\}

Vanderberg SA. Motivational interviewing as a precursor to a substance abuse program for offenders. Doctoral thesis, Department of Psychology, Carlton University, Ottawa, Ontario 2002.

Walters 2014 \{published data only\} Walters ST, Ondersma SJ, Ingersoll KS, Rodriguez M, Lerch J, Rossheim ME, et al. MAPIT: development of a web-based intervention targeting substance abuse treatment in the criminal justice system. Journal of Substance Abuse Treatment 2014;46(1):60-5.

Wang 2010 \{published data only\}

Wang EA, Moore BA, Sullivan LE, Fiellin DA. Effect of incarceration history on outcomes of primary care officebased buprenorphine/naloxone. Journal of General Internal Medicine 2010;25(7):670-4.

Webster 2014 \{published data only\}

Webster JM, Staton-Tindall M, Dickson MF, Wilson JF, Leukefeld CG. Twelve-month employment intervention outcomes for drug-involved offenders. American Journal of Drug and Alcohol Abuse 2014;40(3):200-5. [DOI: 10.3109/00952990.2013.858722]

White 2006 \{published data only\} White MD, Goldkamp JS, Robinson JB. Acupuncture in drug treatment: exploring its role and impact on participant behavior in the drug court setting. Journal of Experimental Criminology 2006; Vol. 2, issue 1:45-65. [: 1573-3750]

Williams 2011 \{published data only\} Williams K, Martin M, Martin D. Examining a drug court treatment program in New Jersey: a perspective from the field. Alcoholism Treatment Quarterly 2011;29(1):85-90.

Winstanley 2011 \{published data only\} Winstanley EL, Bigelow GE, Silverman K, Johnson RE, Strain EC. A randomized controlled trial of fluoxetine in the treatment of cocaine dependence among methadonemaintained patients. Journal of Substance Abuse Treatment 2011;40(3):255-64.

Witkiewitz 2010 \{published data only\} Witkiewitz K, Bowen S. Depression, craving, and substance use following a randomized trial of mindfulness-based relapse prevention. Journal of Consulting and Clinical Psychology 2010;78(3):362-74.

Wolff 2012 \{published data only\} Wolff N, Frueh BC, Shi J, Schumann BE. Effectiveness of cognitive-behavioral trauma treatment for incarcerated women with mental illnesses and substance abuse disorders. Journal of Anxiety Disorders 2012;26(7):703-10. [DOI: 10.1016/j.janxdis.2012.06.001]

Wright 2011 \{published data only\}

Wright N, Sheard L. Comparison of methadone and buprenorphine for opiate detoxification (LEEDS trial): a randomised controlled trial. British Journal of General Practice 2011;e773:772-80.

Zlotnick 2009 \{published data only\}

Zlotnick C, Johnson J, Najavits LM. Randomized controlled pilot study of cognitive-behavioral therapy in a sample of incarcerated women with substance use disorder and PTSD. Behavior Therapy 2009; Vol. 40, issue 4:325-36. [: 0005-7894]

\section{References to ongoing studies}

\section{Springer ongoing \{unpublished data only\}} Springer SA. Naltrexone for opioid dependent released HIV+ criminal justice populations. http://www.yalestudies.org/ 
clinicalTrials/displayTrial.asp?nctID=OnCore1007007169

(accessed May 2014) ongoing-2015.

\section{Additional references}

\section{Andrews 1990}

Andrews DA, Zinger I, Hoge RD, Bonta J, Gendreau P, Cullen FT. Does correctional treatment work? A clinically relevant and psychologically informed meta analysis. Criminology 1990;28:369-404.

\section{Austin 1994}

Austin CD, McLelland RW. Case management in human services: reflections on public policy. Journal of Case Management 1994;6:119-26.

\section{Clarke 2010}

Clarke K. Green paper evidence report: Breaking the cycle, effective punishment, rehabilitation and sentencing of offenders. Ministry of Justice 2010.

Drummond 1997 Drummond M, O'Brien B, Stoddart G, Torrance G. Methods for the Economic Evaluation of Health Care Programmes. 2nd Edition. Oxford: Oxford University Press, 1997.

Fazel 2002

Fazel S, Danesh J. Serious mental disorder in 23000 prisoners: a systematic review of 62 surveys. The Lancet 2002;359:545-50.

\section{Fontanarosa 2013}

Fontanarosa J, Unl S, Oyesanmi O, Schoelles KM. Interventions for adult offenders with serious mental illness. Comparative Effectiveness Reviews number 121. Rockville (MD) Agency for Healthcare Research and Quality 2013.

\section{Glase 2006}

Glase, L.E, James, D.J. Mental health problems of prison and jail inmates, Bureau Justice Statistics Special Report. US Department of Justice, Office of Justice Programs 2006; Vol. NCJ 213600.

Hayes 2004

Hayes, S. C. Mindfulness and acceptance: Expanding the cognitive behavioral tradition. In: S. C. Hayes, V. M. Follette, \& M. Linehan editor(s). Acceptance and Commitment Therapy and the new behavior therapies: Mindfulness, acceptance and relationship. New York: Guildford, 2004:1-29.

\section{Higgins 2011}

Higgins JPT, Green S (editors). Cochrane Handbook for Systematic Reviews of Interventions Version 5.1.0 [updated March 2011]. The Cochrane Collaboration, 2011. Available from www.cochrane-handbook.org.

\section{Lamb 1998}

Lamb RH, Weinberger LE. Persons with severe mental illness in jails and prisons: a review. Psychiatric Services 1998;49:4.

Lipsey 1998

Lipsey MW, Wilson DB. Effective intervention for serious juvenile offenders: a synthesis of research. In: Loeber
R, Farrington DP editor(s). Serious \& Violent Juvenile Offenders: Risk Factors and Successful Intervention. Thousand Oaks, CA: Sage Publications, 1998:313-45.

Lipsey 2007

Lipsey M, Landenberger NA, Wilson SJ. Effects of cognitive-behavioral programs for criminal offenders: a systematic review. Campbell Collaboration 2007; Vol. 3, issue 6 .

\section{Marlowe 2003b}

Marlowe D, Elwork A, Festinger D, McLellan AT. Drug policy by popular referendum: this too shall pass. Journal of Substance Abuse Treatment 2003;25:213-21.

\section{McCollister 2013}

McCollister KE, French MT, Prendergast M, Wexler H, Sacks S, Hall E. Is in prison treatment enough? A cost effectiveness analysis of prison-based treatment and aftercare services for substance abusing offender. Law and Policy 2013; Vol. 25, issue 1:63-82.

\section{McMurran 2009}

McMurran M. Motivational Interviewing with offenders. A systematic review. Legal and Criminological Psychology 2009; 14:83-100.

\section{Miller 1991}

Miller WR, Rollnick S. Motivational Interviewing. Preparing People to Change Addictive Behaviour. New York: Guildford, 1991.

\section{Ministry of Justice 2010}

Ministry of Justice. Green paper evidence report: Breaking the cycle: Effective punishment, rehabilitation and sentencing of offenders. https://www.gov.uk/government/ uploads/system/uploads/attachment' data/file/185947/ green-paper-evidence-a.pdf (accessed May 2014).

\section{Mitchell 2012a}

Mitchell O, Mackenzie LD, Wilson D. The effectiveness of incarcerated based drug treatment on criminal behaviour: a systematic review. Campbell Collaboration 2012; Vol. 8, issue 18.

\section{Partridge 2004}

Partridge S. Examining case management models for community sentences. http://www.cep-probation.org/ uploaded files/Partridge\%20Report.pdf (accessed May 2014).

\section{Pearson 1999}

Pearson FS, Lipton DS. A meta-analytic review of the effectiveness of corrections-based treatment for drug abuse. Prison Journal 1999;79(4):384-410.

\section{Perry 2013a}

Perry AE, Neilson M, Martyn-St James M, Hewitt C, Glanville JM, McCool R, et al. Non-pharmacological interventions for drug using offenders. Cochrane Database of Systematic Reviews in press.

\section{Perry 2013b}

Perry AE, Neilson M, Martyn-St James M, Hewitt C, Glanville JM, McCool R, et al. Pharmacological interventions for drug using offenders. Cochrane Database 
of Systematic Reviews 2013, Issue 12. [DOI: 10.1002/ 14651858.CD010862]

Perry 2006

Perry A, Coulton S, Glanville J, Godfrey C, Lunn J, McDougall C, et al. Interventions for drug-using offenders in the courts, secure establishments and the community. Cochrane Database of Systematic Reviews 2006, Issue 3. [DOI: 10.1002/14651858.CD005193.pub2]

Perry 2013c

Perry AE, Neilson M, Martyn-St James M, Hewitt C, Glanville JM, McCool R, et al. Interventions for drugusing female offenders. Cochrane Database of Systematic Reviews in press.

\section{Prendergast 2003}

Prendergast ML, Hall EA, Wexler HK. Multiple measures of outcome in assessing a prison-based drug treatment program.. Journal of Offender Rehabilitation 2003;37: 65-94.

\section{Prendergast 2004}

Prendergast ML, Hall EA, Wexler HK, Melnick G, Cao Y. Amity prison-based therapeutic community: 5-year outcomes. Prison Journal 2004;84(1):36-50.
RevMan 2012

The Nordic Cochrane Centre, The Cochrane Collaboration. Review Manager. 5.2. Copenhagen: The Nordic Cochrane Centre, The Cochrane Collaboration, 2012.

\section{Sarteschi 2011}

Sarteschi CM, Vaughn MG, Kim K. Assessing the effectiveness of mental health courts: a quantitative review. Journal of Criminal Justice 2011;39:12-20.

\section{Smedslund 2011}

Smedslund G, Berg RC, Hammerstrøm KT, Steiro A, Leiknes KA, Dahl HM, et al. Motivational interviewing for substance abuse. Campbell Collaboration Systematic Review 2011; Vol. 7, issue 6.

\section{Steadman 2009}

Steadman HJ, Osher FC, Robbins C, Case B, Samuels S. Prevalence of serious mental illness among jail inmates. Psychiatric Services 2009;60:761-5.

\section{Vasilaki 2006}

Vasilaki E, Hosier SG, Cox WM. The efficacy of motivational interviewing as a brief intervention for excessive drinking. A meta-analytical review. Alcohol and Alcoholism 2006;41:328-35.

* Indicates the major publication for the study 


\section{CHARACTERISTICS OF STUDIES}

\section{Characteristics of included studies [ordered by study ID]}

\section{Cosden 2003}

Methods

Allocation: random assignment

Randomisation method: adequate/low risk

Similar on drug use: unknown/unclear risk

Similar on criminal activity: yes

Blinding methodology: high risk

Loss to follow-up: partial/high risk

$\begin{array}{ll}\text { Participants } & 235 \text { adults } \\ \text { Age not reported } & 50.2 \% \text { male } \\ & 70.6 \% \text { European American } \\ \text { Drug use not reported } & \text { Alcohol use not reported } \\ 100 \% \text { psychiatric history } & \text { Eligibility criteria: adults charged with a crime or misdemeanour who were booked into } \\ \text { county jail, had at least } 1 \text { prior booking and were diagnosed with a serious and pervasive } \\ \text { mental illness and were residents of the county involved. Pre-plea participants were } \\ \text { required to have no previous offences involving violence; post-adjudication participants } \\ \text { with prior violence were eligible if they were considered to no longer pose a threat }\end{array}$

Interventions

Court-based sentencing and case management intervention vs. treatment as usual

(I) MHTC and ACT case management ( $\mathrm{n}=137)$ vs. (C) treatment as usual ( $\mathrm{n}=98)$

(I) received weekly or bi-weekly court supervision and frequent contact with case managers, duration 18 months, followed by treatment as usual if required

(C) received traditional court proceedings and county mental health services as usual for at least 18 months, which was less intensive than (I)

Outcomes

Drug use (Addiction Severity Index, self report) during the last month at 12 months' follow-up

Re-arrests dichotomous outcomes.

Notes

This research was sponsored by a grant from the California State Board of Corrections, the Mentally Ill Offender Crime Reduction Grant Program.

Contract/grant sponsor: California State Board of Corrections

No declaration of interest reported by the authors

\section{Risk of bias}

\begin{tabular}{l|ll} 
Bias & Authors' judgement & Support for judgement \\
\hline $\begin{array}{l}\text { Random sequence generation (selection } \\
\text { bias) }\end{array}$ & Low risk & Random number table \\
\hline Allocation concealment (selection bias) & Unclear risk & Not reported \\
\hline Interventions for drug-using offenders with co-occurring mental illness (Review)
\end{tabular}




\section{Cosden 2003 (Continued)}

\begin{tabular}{l|l}
$\begin{array}{l}\text { Blinding of participants and personnel High risk } \\
\text { (performance bias) } \\
\text { subjective outcomes }\end{array}$ & $\begin{array}{l}\text { The interviewer was not blind to the con- } \\
\text { dition of the } \\
\text { client }\end{array}$ \\
\hline
\end{tabular}

Blinding of participants and personnel High risk (performance bias)

The interviewer was not blind to the conobjective outcomes dition of the

client

Blinding of outcome assessment (detection Unclear risk

No information available bias)

subjective outcomes

\begin{tabular}{|c|c|c|}
\hline $\begin{array}{l}\text { Blinding of outcome assessment (detection } \\
\text { bias) } \\
\text { objective outcomes }\end{array}$ & Unclear risk & No information available \\
\hline $\begin{array}{l}\text { Incomplete outcome data (attrition bias) } \\
\text { All outcomes }\end{array}$ & High risk & $\begin{array}{l}25 \% \text { of the initial population could not be } \\
\text { located at the end of } 12 \text { months }\end{array}$ \\
\hline Selective reporting (reporting bias) & Unclear risk & Not reported \\
\hline Other bias & High risk & $\begin{array}{l}\text { The relatively small number of clients in } \\
\text { each group resulted in chance variation on } \\
\text { some of the intake measures. Generalisabil- } \\
\text { ity issues and concerns about self report } \\
\text { measures and validity }\end{array}$ \\
\hline
\end{tabular}

Johnson 2012

Methods

Participants
Allocation: random - wave randomisation

Randomisation method: independently generated randomisation sequence. Exact methodology unclear

Similar on drug use: yes

Similar on criminal activity: yes

Blinding methodology: Principal investigator blinded to initial allocation, data collectors blinded throughout study period.

Loss to follow-up: none reported

38 adults

Average age: 35 years (SD 9.2)

$100 \%$ female

$18 \%$ Hispanic, $18 \%$ African American

$58 \%$ cocaine dependence, $24 \%$ opiate dependence, $21 \%$ marijuana dependence, $21 \%$ sedative/hypnotic dependence

$58 \%$ alcohol dependence

$100 \%$ psychiatric history

Criteria used for mental health diagnoses: "MDD as determined by the Structured 

18 , substance use disorder 1 month prior to incarceration as determined by the SCID, 10-24 weeks away from prison release. Women with bipolar disorder and psychotic disorder were excluded

Interventions
Prison-based, non-pharmacological intervention vs attention-matched control condition (I) Interpersonal psychotherapy $(\mathrm{n}=19)$ vs $(\mathrm{C})$ psycho-education $(\mathrm{n}=19)$

Intervention group

Intervention participants received manualised 60-75 min group sessions 3 times per week for 8 weeks plus pre-group, mid-group, and post-group individual sessions in prison for the treatment of substance misuse and mental health problems. Participants in both conditions also received 6 weekly post-release individual sessions to help maintain gains and address crises as they transitioned to the community. Session lengths varied between 60 and 75 min because of time taken to assemble women within the facilities, occasional early prison counts, and other facility logistics. In-prison treatment was condensed into 2 months because many incarcerated women serve short sentences (30, 60, 90, 180 days) . Group sessions were kept short ( 60 to $75 \mathrm{~min}$ ) because prison providers advised us that incarcerated women would have difficulty tolerating treatment sessions longer than this length

Control group

Control condition participants received attention-matched manualised in-prison and post-release psycho-education, which is described as co-occurring mental health and substance use disorders (PSYCHOED). The psycho-education condition was adapted from a class on co-occurring disorders for prisoners that had been used at the women's facilities in the past, but was not being used at the time of the study. It was designed to be credible and engaging without focusing on the theorised active ingredients of interpersonal psychotherapy (e.g., focus on social support, relationships, life changes, analysis of communication, and exploration of emotions). The stated purpose of PSYCHOED was to help women become informed and empowered consumers of mental health treatment services. The 24 in-prison sessions focused on the meaning of dual diagnosis, women's experience with dual diagnosis, major depression, bipolar disorder, each of the anxiety disorders, post-traumatic stress disorder, personality disorders, psychotic disorders, eating disorders, and self care. Sessions for each disorder described symptoms (including relevant self report tests), interactions between the disorder and substance use, effects of the disorder on women in prison (including film clips and written stories), and disorderspecific medication and psychosocial treatment options. When a woman in group had symptoms of a disorder, the group discussed her treatment options and preferences. The 6 post-release sessions focused on women's symptoms and connection with various mental health and substance use treatment options in the community. Study treatments took place in addition to prison treatment as usual. Treatment as usual consisted of prison residential or day treatment for substance use disorder (typically 16 to 30 hours per week) for all participants and prison mental health treatment as usual for most participants 
Johnson 2012 (Continued)

\begin{tabular}{|c|c|c|}
\hline Outcomes & \multicolumn{2}{|c|}{$\begin{array}{l}\text { Relapse within } 3 \text {-month follow-up period, defined as using drugs on at least } 10 \% \text { of non- } \\
\text { incarcerated days or any positive breath test/urine drug screen. Hamilton Depression } \\
\text { Scale scores }\end{array}$} \\
\hline Notes & \multicolumn{2}{|c|}{$\begin{array}{l}\text { Work supported by US National Institute of Drug Abuse. } \\
\text { No declarations of interest were noted by the authors. }\end{array}$} \\
\hline \multicolumn{3}{|l|}{ Risk of bias } \\
\hline Bias & Authors' judgement & Support for judgement \\
\hline $\begin{array}{l}\text { Random sequence generation (selection } \\
\text { bias) }\end{array}$ & Low risk & $\begin{array}{l}\text { Random sequence generated by person in- } \\
\text { dependent of rest of study. Wave randomi- } \\
\text { sation used with at least } 8 \text { weeks between } \\
\text { allocation to avoid contamination across } \\
\text { prison wings }\end{array}$ \\
\hline Allocation concealment (selection bias) & Low risk & $\begin{array}{l}\text { Allocation adequately concealed from prin- } \\
\text { cipal investigator and research assistants. } \\
\text { An independent individual concealed the } \\
\text { assignment of each wave before the study } \\
\text { started. After the intake assessment was } \\
\text { complete, the principal investigator un- } \\
\text { sealed the waves treatment assignment }\end{array}$ \\
\hline
\end{tabular}

Blinding of participants and personnel Unclear risk

Not reported

(performance bias)

subjective outcomes

\begin{tabular}{l|l|l}
\hline $\begin{array}{l}\text { Blinding of participants and personnel } \\
\text { (performance bias) } \\
\text { objective outcomes }\end{array}$ & Not reported \\
\hline
\end{tabular}

Blinding of outcome assessment (detection Low risk bias)

subjective outcomes

Blinding of outcome assessment (detection Low risk bias)

objective outcomes

Incomplete outcome data (attrition bias) Low risk All outcomes
Adequate blinding throughout study. Research assistants who conducted the followup assessment at 3 months after prison release were kept blind to the condition

Adequate blinding throughout study. Research assistants who conducted the followup assessment at 3 months after prison release were kept blind to the condition

No loss to follow-up, intention-to-treat analysis 
Johnson 2012 (Continued)

\begin{tabular}{|c|c|c|}
\hline Selective reporting (reporting bias) & High risk & $\begin{array}{l}\text { Did not report on SCID-I/SCID-II, } \\
\text { Trauma History Questionnaire, or Time- } \\
\text { line Followback }\end{array}$ \\
\hline Other bias & High risk & $\begin{array}{l}\text { Authors noted that the short timeline and } \\
\text { limited outcomes made it difficult to as- } \\
\text { sess relapse rates, as } 26 \% \text { of the sample re- } \\
\text { mained in residential treatment at the end } \\
\text { of the study }\end{array}$ \\
\hline
\end{tabular}

Lanza 2013

Methods

Allocation: Allocation did not seem to be concealed

Randomisation method: randomisation table

Similar on drug use: No differences between the groups for "demographic characteristics" but not sure if this includes drug use. unclear

Similar on criminal activity: No differences between the groups for "demographic characteristics" but not sure if this includes criminal activity. unclear

Blinding methodology: Participants, investigators, and assessors were not blinded

Loss to follow-up: All participants lost to follow-up were reported in study flow diagram, but the authors did not report if there were between-group differences

50 adults

Average age: overall mean 33.2 (SD 7.2) (range 21-49)

(cognitive behavioural therapy 35.2 (mean); acceptance and commitment therapy 31.1 (mean); control 33.1 (mean))

$100 \%$ female

$\%$ white, not reported

$\%$ drug users: CBT 100\%, ACT $83.3 \%$, control 100\%

$\%$ alcohol users: CBT $0 \%$, ACT $16.7 \%$, control $100 \%$

$\%$ psychiatric history: $86 \%$ had at least 1 mental disorder

Eligibility criteria:

- met diagnostic criteria for current substance use disorder

- serving sentence of more than 6 months

Intervention 1: cognitive behavioural therapy (CBT: $\mathrm{n}=13)$ vs Intervention 2: acceptance and commitment therapy (ACT: $\mathrm{n}=18)$ vs Control group $(\mathrm{n}=13)$

Intervention 1

16 weekly CBT group sessions lasting 90 minutes led by a trained therapist. CBT was used to change behaviour through cognitive restructuring, where therapist works with offender to identify thoughts that cause distress and uses CBT to alter resulting behaviour. Treatment offenders were assessed by the therapist afterwards, and followup was conducted at six months. The main outcome of the CBT intervention was to increase abstinence from drug use; this was measured and corroborated by urine analysis testing

Intervention 2

16 weekly ACT group sessions lasting 90 minutes led by a trained therapist. ACT seeks to undermine the grip of the literal verbal content of cognition that provokes avoidance 


behaviour and constructs an alternative context in which behaviour aligned with one's
values is more likely to occur. Sessions involve both experiential and didactic learning to
enable clients to experience and understand the key ACT processes. ACT helps offenders
to respond to previously avoided events in new ways and uses validation and empow-
erment. The ACT therapy was aimed at increasing substance use abstinence within the
prison population. Treatment offenders were assessed by the therapist afterwards, and
follow-up was conducted at six months
Control group
Control group received a mental health assessment and then after 6 months received
treatment. The offenders received a re-educational programme for inmates during the 6
months

\section{Risk of bias}

\begin{tabular}{l|l|l}
\hline Bias & Authors' judgement & Support for judgement \\
\hline $\begin{array}{l}\text { Random sequence generation (selection } \\
\text { bias) }\end{array}$ & Low risk & Use of random number table noted. \\
\hline $\begin{array}{l}\text { Allocation concealment (selection bias) } \\
\begin{array}{l}\text { Blinding of participants and personnel } \\
\text { (performance bias) } \\
\text { subjective outcomes }\end{array}\end{array}$ & High risk & No information reported. \\
\hline $\begin{array}{l}\text { Blinding of participants and personnel } \\
\text { (performance bias) } \\
\text { objective outcomes }\end{array}$ & High risk & $\begin{array}{l}\text { Participants, investigators, and assessors } \\
\text { were not blinded to treatment allocation }\end{array}$ \\
\hline
\end{tabular}

Blinding of outcome assessment (detection Low risk bias)

subjective outcomes

Blinding of outcome assessment (detection High risk bias)

objective outcomes
Urinalysis was used to corroborate self reported abstinence

Therapists assessed the participants in their group. 
Lanza 2013 (Continued)

\begin{tabular}{l|l|l}
$\begin{array}{l}\text { Incomplete outcome data (attrition bias) } \\
\text { All outcomes }\end{array}$ & Low risk & $\begin{array}{l}\text { Similiar loss to follow-up across all } 3 \\
\text { groups. A total of } 9 / 50 \text { lost }(\mathrm{n}=4 \text { for ACT, } \\
\mathrm{n}=3 \text { for CBT, } \mathrm{n}=2 \text { for control) }\end{array}$ \\
\hline $\begin{array}{l}\text { Selective reporting (reporting bias) } \\
\text { Other bias }\end{array}$ & Low risk & $\begin{array}{l}\text { All outcome measures were reported as ex- } \\
\text { pected }\end{array}$ \\
\hline
\end{tabular}

\section{Sacks 2004}

Methods

Allocation: random assignment

Randomisation method: unclear

Similar on drug use: no

Similar on criminal activity: yes

Blinding methodology: unknown/unclear risk

Loss to follow-up: adequate/low risk

Participants

236 adults

Mean age 34.3 years (SD 8.8)

$100 \%$ male

$49 \%$ white

$100 \%$ drug-using

$32 \%$ alcohol-using

$100 \%$ psychiatric history

Eligibility criteria: prisoners who had both a serious mental disorder and a substance use disorder

Interventions

Secure establishment-based therapeutic community vs. treatment as usual

(I) Personal reflections TC and voluntary residential aftercare $(\mathrm{n}=142)$ vs. (C) mental health programme combined with a substance use education course $(n=94)$

Intervention group

Therapeutic communities have long been recognized as a major drug abuse treatment approach, particularly for the socially disaffiliated. TC has an established record of effectiveness in reducing drug use and criminality. The Personal Reflections initiative is a modified TC residential treatment programme that uses a cognitive behavioral curriculum within a foundation of TC principles to change attitudes and lifestyles in 3 critical areas: substance abuse, mental illness, and criminal thinking and behavior. The intervention group received a mixture of psycho-educational classes, cognitive behavioural methods, medication, and group therapy. Activities were attended 5 days per week for 45 hours per day with the rest of the day spent working in the prison; duration 12 months. Aftercare included mental health counselling, medication and psychiatric services, and basic skills. Activities were attended 3-7 days per week for 3-5 hours per day; duration 6 months

Control group

The control group received intensive psychiatric services with medication, weekly individual therapy and counselling, and specialised groups of cognitive behavioural work, anger management, therapy and education, domestic violence, parenting, and weekly

Interventions for drug-using offenders with co-occurring mental illness (Review) 
drug/alcohol therapy with a 72-hour course on substance abuse education and relapse prevention over a duration of 12 months

\begin{tabular}{|c|c|}
\hline Outcomes & $\begin{array}{l}\text { Sacks } 2004 \text { - Primary study } \\
\text { Criminal activity regarding a new offence (official records) during the last } 12 \text { months at } \\
\text { 12-months follow-up } \\
\text { Incarceration for a new offence (official records) during the last } 12 \text { months at } 12 \text {-months } \\
\text { follow-up } \\
\text { Sullivan } 2007 \text { - Follow-up study } \\
\text { Drug use (self report) at } 12 \text { months }\end{array}$ \\
\hline Notes & $\begin{array}{l}\text { Contract/grant sponsor: National Institute on Drug Abuse (NIDA); contract/grant num- } \\
\text { ber: P50 DA } \\
7700.0003 \text {. } \\
\text { No declaration of interest reported by the authors. }\end{array}$ \\
\hline
\end{tabular}

\section{Risk of bias}

\begin{tabular}{|c|c|c|}
\hline Bias & Authors' judgement & Support for judgement \\
\hline $\begin{array}{l}\text { Random sequence generation (selection } \\
\text { bias) }\end{array}$ & Unclear risk & Participants were randomly assigned p. 824 \\
\hline Allocation concealment (selection bias) & Unclear risk & Method of concealment not reported \\
\hline $\begin{array}{l}\text { Blinding of participants and personnel } \\
\text { (performance bias) } \\
\text { subjective outcomes }\end{array}$ & Unclear risk & No information on blinding reported \\
\hline $\begin{array}{l}\text { Blinding of participants and personnel } \\
\text { (performance bias) } \\
\text { objective outcomes }\end{array}$ & Unclear risk & No information on blinding reported \\
\hline $\begin{array}{l}\text { Blinding of outcome assessment (detection } \\
\text { bias) } \\
\text { subjective outcomes }\end{array}$ & Unclear risk & No information on blinding reported \\
\hline $\begin{array}{l}\text { Blinding of outcome assessment (detection } \\
\text { bias) } \\
\text { objective outcomes }\end{array}$ & Unclear risk & No information on blinding reported \\
\hline $\begin{array}{l}\text { Incomplete outcome data (attrition bias) } \\
\text { All outcomes }\end{array}$ & High risk & $\begin{array}{l}\text { Some difference between the groups. At fol- } \\
\text { low-up, } 82 \% \text { for the (I) group and } 69 \% \\
\text { for the (C) group. ITT was performed and } \\
\text { missing data was added to the data set }\end{array}$ \\
\hline Selective reporting (reporting bias) & Unclear risk & Limited information \\
\hline
\end{tabular}


Sacks 2004 (Continued)

Other bias

Unclear risk

No other obvious concerns with the study but difficult to assess

Sacks 2008

Methods

Allocation: random assignment

Randomisation method: unclear

Similar on drug use: yes

Similar on criminal activity: yes

Blinding methodology: unknown

Loss to follow-up: high risk--intention to treat noted

Participants

Sacks 2008 - primary study

573 adult women

Mean age 35.6 (SD 7.5)

$100 \%$ female

$47.8 \%$ white

$99 \%$ drug-using

Eligibility criteria: female inmates with at least 6 months remaining until parole with serious substance abuse problems requiring treatment and presenting a minimum/medium security risk

\section{Sacks 2012 - follow-up study at 6 and 12 months}

468 adult females

Average age: 35.1 years (SD 7.9)

$100 \%$ female

$47 \%$ white

$26 \%$ Hispanic

$100 \%$ drug users (as measured by Standardized Offender Assessment score)

Alcohol use: not reported

$58 \%$ lifetime mental health treatment

Eligibility criteria: female offenders at Denver Women's Correctional Facility; at least 6 months, but no greater than 24 months remaining before parole eligibility; Colorado Department of Corrections Standardized Offender Assessments score of 4 or higher (indicating substance use disorder severe enough to require treatment); security risk level allowing participation in programme; consented

Interventions

(I) Therapeutic community programme $(\mathrm{n}=257)$ vs $(\mathrm{C})$ cognitive behavioural intervention $(\mathrm{n}=211)$

Intervention group

Therapeutic communities were initially designed for use in community-based residential settings, and the model has been successfully adapted for inmate populations. The model has been further modified for male inmates with co-occurring serious mental and substance use disorders, with previous evidence showing positive outcomes for reincarceration, substance use, and mental health symptoms. The intervention involved a 6-month tenure in a separate residential building with programme activities 4 hours per day, 5 days per week, supplemented by peer-led activities on weekends, and a further 4 hours per day, 5 days per week working within the prison complex. The programme followed therapeutic community principles, with additional gender-specific aspects

Interventions for drug-using offenders with co-occurring mental illness (Review)

Copyright @ 2015 The Cochrane Collaboration. Published by John Wiley \& Sons, Ltd. 


Control group
The control programme, known as the Intensive Outpatient Program, is the standard
treatment that the Colorado Department of Corrections offers to all female offenders
who have been classified as substance abusers. The intervention is designed to address
substance abuse and criminality, with a focus on prevention of relapse and recidivism.
The Intensive Outpatient Program substance abuse treatment curriculum consists of a
90-hour course, presented in an educational format (Strategies for Self-Improvement
and Change, Wanburg \& Milkman, 1998), utilising a cognitive behavioural format to
address underlying issues of substance use/abuse and criminal behavior. The course is
completed within 15 weeks. Women in the programme can participate in multiple other
services facility-wide including mental health assessments

Outcomes

Notes
Criminal activity, arrest, and drug-related activity (self reported) at 6 and 12 months, and criminal record data (\% incarcerated, mean days to incarceration) at 12 months post-prison release

Self reported illegal drug use at 6 and 12 months

Work supported by US Department of Health and Human Services, National Institutes of Health, National Institute on Drug Abuse

No declarations of interest are noted by the authors

\section{Risk of bias}

\begin{tabular}{l|ll} 
Bias & Authors' judgement & Support for judgement \\
\hline $\begin{array}{l}\text { Random sequence generation (selection } \\
\text { bias) }\end{array}$ & Unclear risk & $\begin{array}{l}\text { No information other than "were randomly } \\
\text { assigned” }\end{array}$ \\
\hline Allocation concealment (selection bias) & Unclear risk & No information provided \\
\hline $\begin{array}{l}\text { Blinding of participants and personnel } \\
\text { (performance bias) } \\
\text { subjective outcomes }\end{array}$ & Unclear risk & $\begin{array}{l}\text { No evidence to suggest blinding was done } \\
\text { but lack of information makes it difficult } \\
\text { to make an assessment }\end{array}$
\end{tabular}

Blinding of participants and personnel Unclear risk (performance bias)

objective outcomes
No evidence to suggest blinding was done but lack of information makes it difficult to make an assessment

No evidence about whether the assessors

were blind

No evidence about whether the assessors were blind
Blinding of outcome assessment (detection Unclear risk bias)

objective outcomes
Blinding of outcome assessment (detection Unclear risk bias)

subjective outcomes
Incomplete outcome data (attrition bias) High risk All outcomes
No loss to follow-up for re-incarceration outcome but loss to follow-up for other 
Sacks 2008 (Continued)

\begin{tabular}{l|l|l} 
& & $\begin{array}{l}\text { outcomes unclear. ITT reported. Differ- } \\
\text { ences also noted between data collected us- } \\
\text { ing self report and official records. Inten- } \\
\text { tion-to-treat analysis used to analyse the } \\
\text { outcome measures }\end{array}$ \\
\hline Selective reporting (reporting bias) & Low risk & No evidence of selective reporting \\
\hline Other bias & Low risk & Protocol noted \\
\hline
\end{tabular}

\section{Sacks 2011}

Methods

Allocation: random assignment

Randomisation method: random number list

Similar on drug use: yes

Similar on criminal activity: yes

Blinding methodology: open label - no blinding

Loss to follow-up: unclear risk

Participants

127 adults

Mean age 38.2 years (SD 9.9)

$100 \%$ male

$56 \%$ white

$100 \%$ co-occurring substance use and mental illness

Alcohol use: unknown

$61.8 \%$ with clinical level of psychological distress as measured by Global Severity Index Eligibility criteria: male, diagnosed with co-occurring mental and substance use disorders, had participated in 1 of 2 prison substance abuse treatment programmes, were approved for placement in a community corrections facility and were accepted by the provider agency for placement in a community corrections facility

Interventions

Secure establishment-based therapeutic community vs. parole supervision case management

(I) re-entry modified TC ( $\mathrm{n}=71)$ vs. (C) parole supervision case management $(\mathrm{n}=56)$ Intervention group

The intervention consisted of a residential programme of 6 months' duration. Formal programme activities 3-7 days per week, 3-5 hours each day. Participants had progressively increasing independence, eventually being responsible for providing counsel, guidance, and coaching for new members. Participants also worked in the community and saved money for independent living. There were weekly group psycho-educational classes to address the interrelationship between mental disorders and substance abuse, as well as various other group and individual counselling sessions. Medication monitoring and psychiatric services were on site. Participants were given assistance with housing and encouragement for employment

Control group

The control participants were released to a community corrections facility, and left the facility during the day to go to work, have treatment, and report to parole officers. The control consisted of outreach and engagement activities, brokering community-based

Interventions for drug-using offenders with co-occurring mental illness (Review) 


\begin{tabular}{|c|c|c|}
\hline & \multicolumn{2}{|c|}{$\begin{array}{l}\text { services, and direct provision of support and counselling services. There was a weekly } \\
\text { relapse prevention group and daily medication monitoring. Psychiatric and substance } \\
\text { abuse services were provided by outside agencies (community parole officers helped client } \\
\text { choose). Unlike in the intervention, criminal thinking and behaviour were not specif- } \\
\text { ically addressed. The average participant attended } 1 \text { group per week and had monthly } \\
\text { psychiatric assessments }\end{array}$} \\
\hline Outcomes & \multicolumn{2}{|c|}{$\begin{array}{l}\text { Rate of re-incarceration, number of days until re-incarceration, involvement in self re- } \\
\text { ported criminal activity, number of days until self reported criminal activity. Alcohol } \\
\text { and drug offences (self reported) \%. Other offences (self reported) \%. All at } 12 \text { months } \\
\text { post-prison release }\end{array}$} \\
\hline Notes & \multicolumn{2}{|c|}{$\begin{array}{l}\text { This project received support from the Department of } \\
\text { Health and Human Services, National Institutes of Health, } \\
\text { NIDA (Grant 5R01DA019982-[01-05]). } \\
\text { No declarations of interest reported by the authors. }\end{array}$} \\
\hline \multicolumn{3}{|l|}{ Risk of bias } \\
\hline Bias & Authors' judgement & Support for judgement \\
\hline $\begin{array}{l}\text { Random sequence generation (selection } \\
\text { bias) }\end{array}$ & Low risk & Random number list \\
\hline Allocation concealment (selection bias) & Unclear risk & Not reported \\
\hline $\begin{array}{l}\text { Blinding of participants and personnel } \\
\text { (performance bias) } \\
\text { subjective outcomes }\end{array}$ & Unclear risk & "Open-label trial”, no blinding possible \\
\hline $\begin{array}{l}\text { Blinding of participants and personnel } \\
\text { (performance bias) } \\
\text { objective outcomes }\end{array}$ & Unclear risk & "Open label trial”, no blinding possible \\
\hline $\begin{array}{l}\text { Blinding of outcome assessment (detection } \\
\text { bias) } \\
\text { subjective outcomes }\end{array}$ & Unclear risk & No information about blinding presented \\
\hline $\begin{array}{l}\text { Blinding of outcome assessment (detection } \\
\text { bias) } \\
\text { objective outcomes }\end{array}$ & Unclear risk & No information about blinding presented \\
\hline $\begin{array}{l}\text { Incomplete outcome data (attrition bias) } \\
\text { All outcomes }\end{array}$ & Unclear risk & Some partial loss to follow-up \\
\hline Selective reporting (reporting bias) & Unclear risk & Not reported \\
\hline Other bias & Low risk & No other obvious concerns with the study \\
\hline
\end{tabular}

Interventions for drug-using offenders with co-occurring mental illness (Review)

Copyright $\odot 2015$ The Cochrane Collaboration. Published by John Wiley \& Sons, Ltd. 
Methods

Allocation: random assignment

Randomisation method: random numbers table

Similar on drug use: yes

Similar on criminal activity: unknown/unclear risk

Blinding methodology: unclear/unknown

Loss to follow-up: partial/unclear risk

Participants 189 adolescents
Mean age 17.12 years (SD 1.10). Range 14-19 years
$85.7 \%$ male
$32.8 \%$ white
$88.9 \%$ marijuana use
$63 \%$ alcohol use
$68.5 \%$ had significant depressive symptomatology during past week at baseline (CES-
D)
Eligibility criteria: $14-19$ years old, sentenced to juvenile correctional facility for 4-12
months, engaged in at least monthly marijuana use or binge-drinking in the year before
incarceration, used any alcohol or marijuana in the month prior to incarceration (or
prior to the offence leading to incarceration)

Interventions

Secure establishment-based motivational interviewing vs. relaxation treatment

(I) MI ( $\mathrm{n}=96)$ vs. $(\mathrm{C})$ relaxation training $(\mathrm{n}=85)$

Intervention group

The intervention was designed specifically to reduce substance use and its associated risks and consequences. Consisted of 90-minute baseline intervention and 60-minute booster intervention within 2 weeks of release

Comparison group

The comparison group consisted of 90-minute baseline intervention and 60-minute booster intervention, and involved relaxation techniques as well as advice on risky behaviours associated with substance use

Outcomes

Mean number of joints per day and mean percentage of days used marijuana at 3 months

Notes

Results presented for both high and low depressive symptom scores. Results used in this review were for those identified as having high depressive symptomatology

This research was supported by National Institute on Drug Abuse Grant

R01 \#13375 (to L.A.R. Stein, principal investigator).

No declaration of interest reported by the authors.

\section{Risk of bias}

\begin{tabular}{lll} 
Bias & Authors' judgement & Support for judgement \\
\hline $\begin{array}{l}\text { Random sequence generation (selection } \\
\text { bias) }\end{array}$ & Low risk & $\begin{array}{l}\text { "Random assignment using a random } \\
\text { number table" }\end{array}$ \\
\hline Allocation concealment (selection bias) & Unclear risk & $\begin{array}{l}\text { "Random number was placed in an enve- } \\
\text { lope and opened by research staff after the } \\
\text { baseline assessment" }\end{array}$
\end{tabular}




\section{Stein 2011 (Continued)}

\begin{tabular}{l|l}
$\begin{array}{l}\text { Blinding of participants and personnel } \\
\text { (performance bias) } \\
\text { subjective outcomes }\end{array}$ & $\begin{array}{l}\text { Researchers were blind until after the } \\
\text { baseline assessment. Participants were not } \\
\text { blinded }\end{array}$
\end{tabular}

Blinding of participants and personnel Unclear risk (performance bias)

Researchers were blind until after the objective outcomes baseline assessment. Participants were not blinded

Blinding of outcome assessment (detection Unclear risk bias)

subjective outcomes

Follow-up assessments at 3 months were completed blind by the researchers but not at any other time point

Blinding of outcome assessment (detection Unclear risk bias)

objective outcomes

Follow-up assessments at 3 months were completed blind by the researchers but not at any other time point

Incomplete outcome data (attrition bias) Unclear risk

Some attrition, particularly for those indiAll outcomes viduals with more severe depression

\begin{tabular}{|c|c|c|}
\hline Selective reporting (reporting bias) & Unclear risk & Limited information \\
\hline Other bias & High risk & $\begin{array}{l}\text { Short follow-up period and concerns about } \\
\text { self report measures }\end{array}$ \\
\hline
\end{tabular}

Wexler 1999

\begin{tabular}{ll} 
Methods & Allocation: random assignment \\
Randomisation method: unclear/unknown & Similar on drug use: yes \\
& Similar on criminal activity: yes \\
& Blinding methodology: unknown/unclear risk \\
& Loss to follow-up: adequate/low risk \\
\hline Participants & 715 adults \\
& Mean age 30.9 years (SD 7.4) \\
& $100 \%$ male \\
& $37.8 \%$ white \\
& $100 \%$ drug-using \\
Alcohol use not reported \\
$100 \%$ psychiatric history \\
Eligibility criteria: offenders with a drug problem who were 9-14 months from parole. \\
Offenders convicted of arson or sexual crimes to minors were not eligible
\end{tabular}

Interventions

Secure establishment-based therapeutic community vs. no treatment

(I) Amity TC and (I1) voluntary residential aftercare $(\mathrm{n}=247)$ vs. (C) waiting-list control ( $\mathrm{n}=290)$

(I) TC included a 2- to 3-month orientation phase, a 5- to 6-month treatment stage, and 
a 1 - to 3-month re-entry phase; total duration 12 months. The intervention elements included a needs assessment, education, group work, counselling, and prison industry jobs

(I1) voluntary residential aftercare in the community for up to 12 months

(C) waiting-list control

\begin{tabular}{|c|c|}
\hline Outcomes & $\begin{array}{l}\text { Wexler 1999a: } \\
\text { Incarceration (official records) during the last } 12 \text { months at } 12 \text { months' follow-up } \\
\text { Incarceration (official records) during the last } 24 \text { months at } 24 \text { months' follow-up } \\
\text { Wexler 1999b: } \\
\text { Incarceration (official records) during the last } 36 \text { months at } 36 \text { months' follow-up } \\
\text { Prendergast 2003: } \\
\text { Arrest for any offence (self report), arrest for a drug offence (self report), incarceration } \\
\text { for any offence (official records) } 12 \text {-months post-release } \\
\text { Prendergast 2004: } \\
\text { Incarceration (official records) during the last } 60 \text { months at } 60 \text { months' follow-up } \\
\text { Drug use (self report) during the last } 60 \text { months at } 60 \text { months' follow-up }\end{array}$ \\
\hline Notes & $\begin{array}{l}\text { This study was a cooperative effort by the Center for Therapeutic Community Research } \\
\text { at } \\
\text { National Development and Research Institutes, Inc. and the California Department of } \\
\text { Corrections and Rehabilitation Office of Substance Abuse Programs. The evaluation was } \\
\text { funded by the National Institute of Drug Abuse, Grant \#PAODA07700-01 }\end{array}$ \\
\hline
\end{tabular}

Risk of bias

\begin{tabular}{l|l|l}
\hline Bias & Authors' judgement & Support for judgement \\
\hline $\begin{array}{l}\text { Random sequence generation (selection } \\
\text { bias) }\end{array}$ & Unclear risk & $\begin{array}{l}\text { It was noted that the participants were "ran- } \\
\text { domly" assigned and stratified by ethnic } \\
\text { makeup. Randomisation only applied to } \\
\text { the TC and not to aftercare }\end{array}$ \\
\hline $\begin{array}{l}\text { Allocation concealment (selection bias) } \\
\text { Blinding of participants and personnel } \\
\text { (performance bias) } \\
\text { subjective outcomes }\end{array}$ & Unclear risk & No information provided \\
\hline
\end{tabular}

Blinding of participants and personnel Unclear risk

No information on blinding was provided (performance bias)

objective outcomes

Blinding of outcome assessment (detection Unclear risk bias)

subjective outcomes 
Wexler 1999 (Continued)

\begin{tabular}{|c|c|c|}
\hline $\begin{array}{l}\text { Blinding of outcome assessment (detection } \\
\text { bias) } \\
\text { objective outcomes }\end{array}$ & Unclear risk & No information on blinding was provided \\
\hline $\begin{array}{l}\text { Incomplete outcome data (attrition bias) } \\
\text { All outcomes }\end{array}$ & Low risk & $\begin{array}{l}\text { Outcomes for the first } 12 \text { months post-re- } \\
\text { lease were obtained for all } 715 \text { participants }\end{array}$ \\
\hline Selective reporting (reporting bias) & Unclear risk & Information not reported \\
\hline Other bias & High risk & $\begin{array}{l}\text { Only the prison phase was randomised. Af- } \\
\text { tercare was voluntary and participants self } \\
\text { selected. Concerns about bias in self selec- } \\
\text { tion processes p.164-165 }\end{array}$ \\
\hline
\end{tabular}

ACT: acceptance and commitment therapy; CBT: cognitive behavioural therapy; CES-D: Center for Epidemiologic Studies Depression Scale; (C): control; DSM-IV: Diagnostic and Statistical Manual of Mental Disorders, Fourth Edition; (I): intervention; ITT: intention to treat; MDD: major depressive disorder; MHTC: mental health treatment court; MI: motivational interviewing; SCID: Structured Clinical Interview for DSM Disorders; SD: standard deviation; TC: therapeutic community.

\section{Characteristics of excluded studies [ordered by study ID]}

\begin{tabular}{l|l}
\hline Study & Reason for exclusion \\
\hline Alemi 2010 & Study population did not have co-occurring mental illness \\
\hline Alessi 2011 & Not original RCT. Data are from previous, older studies \\
\hline Andersson 2014 & Intervention not aimed at reducing drug use or criminal activity, or both \\
\hline Anglin 1999 & $\begin{array}{l}\text { The study did not report relevant drug or crime outcome (or both) measures at both the pre- and } \\
\text { post-intervention periods }\end{array}$ \\
\hline Awgu 2010 & $\begin{array}{l}\text { The study did not report relevant drug or crime outcome (or both) measures at both the pre- and } \\
\text { post-intervention periods }\end{array}$ \\
\hline Azbel 2013 & Intervention not aimed at reducing drug use or criminal activity, or both \\
\hline Baldus 2011 & Study protocol only \\
\hline Baltieri 2014 & Intervention not aimed at reducing drug use or criminal activity, or both \\
\hline Barnes 2012 & Intervention not aimed at reducing drug use or criminal activity, or both \\
\hline
\end{tabular}

Interventions for drug-using offenders with co-occurring mental illness (Review) 
(Continued)

\begin{tabular}{|c|c|}
\hline Bayanzadeh 2004 & Did not provide mental health information \\
\hline Berman 2004 & Intervention not aimed at reducing drug use or criminal activity, or both \\
\hline Black 2011 & Not an offender population \\
\hline Brady 2010 & Not RCT \\
\hline Braithwaite 2005 & $\begin{array}{l}\text { The study did not report relevant drug or crime outcome (or both) measures at both the pre- and } \\
\text { post-intervention periods }\end{array}$ \\
\hline Breckenridge 2000 & Evaluated a DWI Court for alcoholic offenders, not illicit drug use \\
\hline Britt 1992 & Did not provide mental health information \\
\hline Brown 2001 & $\begin{array}{l}3 \text {-arm study in which only } 2 \text { arms were randomised -- } 1 \text { treatment arm and control arm. Results } \\
\text { presented as both treatment arms combined vs. control }\end{array}$ \\
\hline Brown 2013 & Did not provide mental health information \\
\hline Burdon 2013 & Did not provide mental health information \\
\hline Carr 2008 & $\begin{array}{l}\text { The population of the study was not } 100 \% \text { drug-using offenders that were specifically referred by } \\
\text { the criminal justice system to the intervention }\end{array}$ \\
\hline Carroll 2006 & Study population did not have co-occurring mental illness \\
\hline Carroll 2011 & Not offender population \\
\hline Carroll 2012 & Did not provide mental health information \\
\hline Chandler 2006 & $\begin{array}{l}\text { The study did not report relevant drug or crime outcome (or both) measures at both the pre- and } \\
\text { post-intervention periods }\end{array}$ \\
\hline Chaple 2014 & No pre- and post-test measures of drug or crime, or both \\
\hline Clair 2013 & No pre- and post-test data on either drug or crime outcomes \\
\hline Cogswell 2011 & Did not present mental health information \\
\hline Cornish 1997 & Study population did not have co-occurring mental illness \\
\hline Cosden 2003a & Did not present mental health information \\
\hline Cosden 2005 & $\begin{array}{l}\text { The study did not report relevant drug or crime outcome (or both) measures at both the pre- and } \\
\text { post-intervention periods }\end{array}$ \\
\hline
\end{tabular}

Interventions for drug-using offenders with co-occurring mental illness (Review) 
(Continued)

\begin{tabular}{|c|c|}
\hline Coviello 2010 & Study population did not have co-occurring mental illness \\
\hline Coviello 2012 & Did not present mental health information \\
\hline Cox 2013 & Not an offender population \\
\hline Cropsey 2011 & Study population did not have co-occurring mental illness \\
\hline Cropsey 2013 & Did not present mental health information \\
\hline Cullen 2011 & Not an intervention aimed at reducing drug use or criminal activity, or both \\
\hline Cusack 2010 & Not an intervention aimed at reducing drug use or criminal activity, or both \\
\hline D’Amico 2013 & Did not present mental health information \\
\hline Dakof 2010 & Study population was mothers of offenders, not offenders themselves \\
\hline Dana 2013 & Not an RCT \\
\hline DeFulio 2013 & Not an RCT \\
\hline Dembo 2000 & $\begin{array}{l}\text { The study did not report relevant drug or crime outcome (or both) measures at both the pre- and } \\
\text { post-intervention periods } \\
\text { The follow-up periods reported for the different groups were not equivalent }\end{array}$ \\
\hline Deschenes 1994 & Study population did not have co-occurring mental illness \\
\hline Di Nitto 2002 & The follow-up periods reported for the different groups were not equivalent \\
\hline Diamond 2006 & $\begin{array}{l}\text { The study did not report relevant drug or crime outcome (or both) measures at both the pre- and } \\
\text { post-intervention periods }\end{array}$ \\
\hline Dolan 2003 & Study population did not have co-occurring mental illness \\
\hline Dole 1969 & No outcome based on mental health problems \\
\hline Dugan 1998 & $\begin{array}{l}\text { The study did not report relevant drug or crime outcome (or both) measures at both the pre- and } \\
\text { post-intervention periods }\end{array}$ \\
\hline Evans 2012 & Not an RCT \\
\hline Forsberg 2011 & Study population did not have co-occurring mental illness \\
\hline Freudenberg 2010 & Study population did not have co-occurring mental illness \\
\hline Friedman 2012 & Not an RCT \\
\hline
\end{tabular}


(Continued)

\begin{tabular}{|c|c|}
\hline Frost 2013 & Not an RCT \\
\hline Gagnon 2010 & Not offender population \\
\hline Gil 2004 & $\begin{array}{l}\text { The study did not report relevant drug or crime outcome (or both) measures at both the pre- and } \\
\text { post-intervention periods }\end{array}$ \\
\hline Gordon 2012 & No pre- and post-test outcomes of drug or criminal activity, or both \\
\hline Gordon 2013 & No relevant primary data, all data presented considered a secondary post hoc analysis \\
\hline Gottfredson 2002 & Study population did not have co-occurring mental illness \\
\hline Grohman 2004 & $\begin{array}{l}\text { The study did not report relevant drug or crime outcome (or both) measures at both the pre- and } \\
\text { post-intervention periods }\end{array}$ \\
\hline Grommon 2013a & Did not contain any mental health information \\
\hline Grommon $2013 b$ & Did not contain any mental health information \\
\hline Guydish 2011 & Study population did not have co-occurring mental illness \\
\hline Guydish 2014 & Not criminal justice population \\
\hline Haapanen 2002 & Study population did not have co-occurring mental illness \\
\hline Haasen 2010 & Not offender population \\
\hline Hanlon 1999 & Study population did not have co-occurring mental illness \\
\hline Harada 2012 & No data at pre- and post-test on outcomes of drug or criminal activity, or both \\
\hline Harrell 2001 & $\begin{array}{l}\text { The study did not report relevant drug or crime outcome (or both) measures at both the pre- and } \\
\text { post-intervention periods }\end{array}$ \\
\hline Henderson 2010 & $\begin{array}{l}\text { The study did not report relevant drug or crime outcome (or both) measures at both the pre- and } \\
\text { post-intervention periods }\end{array}$ \\
\hline Henggeler 1991 & $\begin{array}{l}\text { The study did not report relevant drug or crime outcome (or both) measures at both the pre- and } \\
\text { post-intervention periods }\end{array}$ \\
\hline Henggeler 1999 & Study population did not have co-occurring mental illness \\
\hline Henggeler 2002 & $\begin{array}{l}\text { The study did not report relevant drug or crime outcome (or both) measures at both the pre- and } \\
\text { post-intervention periods }\end{array}$ \\
\hline Henggeler 2006 & Study population did not have co-occurring mental illness \\
\hline
\end{tabular}


(Continued)

\begin{tabular}{|c|c|}
\hline Henggeler 2012 & Study population did not have co-occurring mental illness \\
\hline Howells 2002 & Study population did not have co-occurring mental illness \\
\hline Hser 2011 & Unclear if study looked at offender population \\
\hline Hser 2013 & Study population did not have co-occurring mental illness \\
\hline Inciardi 2004 & Some participants were not randomly selected into the treatment groups \\
\hline Jain 2011 & Not an offender population \\
\hline Johnson 2011 & Study population did not have co-occurring mental illness \\
\hline Jones 2011 & Evaluated a DWI Court for alcoholic offenders, not illicit drug use \\
\hline Jones 2013 & Study population did not have co-occurring mental illness \\
\hline Katz 2007 & $\begin{array}{l}\text { The population of the study was not } 100 \% \text { drug-using offenders that were specifically referred by } \\
\text { the criminal justice system to the intervention }\end{array}$ \\
\hline Kelly 2013 & Study population did not have co-occurring mental illness \\
\hline Kidorf 2013 & Not an offender population \\
\hline King 2014 & Not an offender population \\
\hline Kinlock 2005 & Study population did not have co-occurring mental illness \\
\hline Kinlock 2007 & Study population did not have co-occurring mental illness \\
\hline Kinlock 2008 & Study population did not have co-occurring mental illness \\
\hline Kinlock 2009 & Conference proceedings only \\
\hline Kinlock 2009b & Study population did not have co-occurring mental illness \\
\hline Kok 2013 & Not offender population \\
\hline
\end{tabular}

Law 2012 The study did not report relevant drug or crime outcome (or both) measures at both the pre- and post-intervention periods

Lee 2012

Study population did not have co-occurring mental illness

Liddle 2011

The study did not report relevant drug or crime outcome (or both) measures at both the pre- and post-intervention periods 
(Continued)

\begin{tabular}{l|l}
\hline Ling 2013 & Not offender population \\
\hline Lobmaier 2010 & Study population did not have co-occurring mental illness \\
\hline Lobmann 2007 & Study population did not have co-occurring mental illness \\
\hline Lobmann 2009 & $\begin{array}{l}\text { The study did not report relevant drug or crime outcome (or both) measures at both the pre- and } \\
\text { post-intervention periods }\end{array}$ \\
\hline MacDonald 2007 & Evaluated a DWI Court for alcoholic offenders, not illicit drug use \\
\hline Magura 2009 & Study population did not have co-occurring mental illness \\
\hline
\end{tabular}

Marlowe 2003 The study did not report relevant drug or crime outcome (or both) measures at both the pre- and post-intervention periods

\begin{tabular}{|c|c|}
\hline Marlowe 2005 & Study population did not have co-occurring mental illness \\
\hline Marlowe 2007 & $\begin{array}{l}\text { Participants were not randomised to treatment group but once in a group were randomised by level } \\
\text { of risk } \\
\text { Not an RCT }\end{array}$ \\
\hline Marlowe 2008 & Study population did not have co-occurring mental illness \\
\hline Marsch 2014 & Not offender population \\
\hline Martin 1993 & Study population did not have co-occurring mental illness \\
\hline Mbilinyi 2011 & Participants not recruited through criminal justice system \\
\hline McKendrick 2007 & $\begin{array}{l}\text { The study did not report relevant drug or crime outcome (or both) measures at both the pre- and } \\
\text { post-intervention periods }\end{array}$ \\
\hline McKenzie 2012 & Did not present mental health information \\
\hline Messina 2000 & $\begin{array}{l}\text { The population of the study was not } 100 \% \text { drug-using offenders that were specifically referred by } \\
\text { the criminal justice system to the intervention } \\
\text { The study did not report relevant drug or crime outcome (or both) measures at both the pre- and } \\
\text { post-intervention periods }\end{array}$ \\
\hline Milloy 2011 & $\begin{array}{l}\text { The study did not report relevant drug or crime outcome (or both) measures at both the pre- and } \\
\text { post-intervention periods }\end{array}$ \\
\hline Needels 2005 & $\begin{array}{l}\text { The population of the study was not } 100 \% \text { drug-using offenders that were specifically referred by } \\
\text { the criminal justice system to the intervention }\end{array}$ \\
\hline
\end{tabular}

Interventions for drug-using offenders with co-occurring mental illness (Review)

Copyright () 2015 The Cochrane Collaboration. Published by John Wiley \& Sons, Ltd. 
(Continued)

\begin{tabular}{|c|c|}
\hline Nemes 1998 & $\begin{array}{l}\text { The population of the study was not } 100 \% \text { drug-using offenders that were specifically referred by } \\
\text { the criminal justice system to the intervention } \\
\text { The study did not report relevant drug or crime outcome (or both) measures at both the pre- and } \\
\text { post-intervention periods }\end{array}$ \\
\hline Nemes 1999 & $\begin{array}{l}\text { The population of the study was not } 100 \% \text { drug-using offenders that were specifically referred by } \\
\text { the criminal justice system to the intervention } \\
\text { The study did not report relevant drug or crime outcome (or both) measures at both the pre- and } \\
\text { post-intervention periods }\end{array}$ \\
\hline Nielsen 1996 & Study population did not have co-occurring mental illness \\
\hline Nosyk 2010 & Not offender population \\
\hline Petersilia 1992 & Did not present mental health information \\
\hline Petry 2005 & Partial criminal justice population \\
\hline Petry 2011 & Not offender population \\
\hline Polsky 2010 & Not offender population \\
\hline Prendergast 2008 & Did not present mental health information \\
\hline Prendergast 2009 & $\begin{array}{l}\text { The study did not report relevant drug or crime outcome (or both) measures at both the pre- and } \\
\text { post-intervention periods }\end{array}$ \\
\hline Prendergast 2011 & Study population did not have co-occurring mental illness \\
\hline Proctor 2012 & Study population did not have co-occurring mental illness \\
\hline Reimer 2011 & Not offender population \\
\hline Robertson 2006 & $\begin{array}{l}\text { The population of the study was not } 100 \% \text { drug-using offenders that were specifically referred by } \\
\text { the criminal justice system to the intervention }\end{array}$ \\
\hline Rosengard 2008 & $\begin{array}{l}\text { The study did not report relevant drug or crime outcome (or both) measures at both the pre- and } \\
\text { post-intervention periods }\end{array}$ \\
\hline Rossman 1999 & Study population did not have co-occurring mental illness \\
\hline Rounsaville 2001 & $\begin{array}{l}\text { The study did not report relevant drug or crime outcome (or both) measures at both the pre- and } \\
\text { post-intervention periods }\end{array}$ \\
\hline Rowan-Szal 2005 & Not offender population \\
\hline Rowan-Szal 2009 & Not RCT \\
\hline
\end{tabular}


(Continued)

\begin{tabular}{|c|c|}
\hline Rowe 2007 & $\begin{array}{l}\text { The population of the study was not } 100 \% \text { drug-using offenders that were specifically referred by } \\
\text { the criminal justice system to the intervention }\end{array}$ \\
\hline Sanchez-Hervas 2010 & Not offender population \\
\hline Schaeffer 2014 & No mental health information \\
\hline Schmiege 2009 & No pre- and post-test data on drug or crime outcome measures, or both \\
\hline Schwartz 2006 & Not offender population \\
\hline Shanahan 2004 & Did not contain a population with mental illness \\
\hline Sheard 2009 & $\begin{array}{l}\text { The study did not report relevant drug or crime outcome (or both) measures at both the pre- and } \\
\text { post-intervention periods }\end{array}$ \\
\hline Siegal 1999 & Not RCT \\
\hline Sinha 2003 & Did not contain a population with mental illness \\
\hline Smith 2010 & Study population did not have co-occurring mental illness \\
\hline Solomon 1995 & Not offender population \\
\hline Specka 2013 & Not offender population \\
\hline Stanger 2009 & $\begin{array}{l}\text { The population of the study was not } 100 \% \text { drug-using offenders that were specifically referred by } \\
\text { the criminal justice system to the intervention }\end{array}$ \\
\hline Staton-Tindall 2009 & No control group, not an RCT \\
\hline Stein 2006 & No data pre- and post-test for drug or crime measures, or both \\
\hline Stein 2010 & Not offender population \\
\hline
\end{tabular}

Stevens 1998 The population of the study was not 100\% drug-using offenders that were specifically referred by the criminal justice system to the intervention

Svikis $2011 \quad$ Not clear if offender population

Taxman 2006/Thanner 2003 Study population did not have co-occurring mental illness

\begin{tabular}{l|l}
\hline Vagenas 2014 & No pre- and post-test data on either drug or crime measures, or both \\
\hline Vanderberg 2002 & No pre- and post-test outcome data on crime or drug measures, or both \\
\hline Walters 2014 & No data on pre- or post-test outcome data on crime or drug measures, or both \\
\hline $\begin{array}{l}\text { Interventions for drug-using offenders with co-occurring mental illness (Review) } \\
\text { Copyright } \odot 2015 \text { The Cochrane Collaboration. Published by John Wiley \& Sons, Ltd. }\end{array}$
\end{tabular}

Copyright $\odot 2015$ The Cochrane Collaboration. Published by John Wiley \& Sons, Ltd. 
(Continued)

\begin{tabular}{ll}
\hline Wang 2010 & Participants not in criminal justice system \\
\hline Webster 2014 & No data on pre- and/or post-test crime and/or drug measures \\
\hline White 2006 & $\begin{array}{l}\text { Randomisation broken as } 40 \% \text { of control arm were allowed to receive treatment (acupuncture) } \\
\text { outside of the intervention }\end{array}$ \\
\hline Williams 2011 & Not RCT \\
\hline Winstanley 2011 & Not clear if offender population \\
\hline Witkiewitz 2010 & Not clear if offender population \\
\hline Wolff 2012 & No data at pre- and/or post-test measures of drug and/or crime measures \\
\hline Wright 2011 & No separate mental health data \\
\hline Zlotnick 2009 & Study population did not have co-occurring mental illness \\
\hline
\end{tabular}

RCT: randomised controlled trial

Characteristics of ongoing studies [ordered by study ID]

\section{Springer ongoing}

Trial name or title Naltrexone for opioid-dependent released HIV+ criminal justice populations Referred to as NEWHOPE.
Methods Our specific aim is to conduct a placebo-controlled randomised controlled trial of depot NTX (d-NTX) for $\mathrm{HIV}+$ prisoners with opioid dependence who are transitioning to the community
150 participants within the criminal justice system in New Haven, Hartford, and Springfield. Subjects will be randomised 2:1 to d-NTX or d-placebo for 6 months and observed for 12 months

Participants

HIV-infected prisoners with opioid dependence who are treated with depot-NTX as they are transitioning from the correctional to the community setting

150 participants

\begin{tabular}{|c|c|}
\hline Interventions & Depot-NTX versus placebo \\
\hline Outcomes & $\begin{array}{l}6 \text { and } 12 \text { months } \\
\text { HIV treatment (HIV-1 RNA levels, CD } 4 \text { count, antiretroviral adherence, retention in care), substance abuse } \\
\text { (time to relapse to opioid use, \% opioid negative urine results, opioid craving), adverse side effects and HIV } \\
\text { risk behavior (sexual and drug-related risks) } \\
\text { The public health relevance is that outcomes from this study will establish the efficacy, safety, and tolerability } \\
\text { of pharmacological therapy using NTX treatment among HIV+s and establish depot-NTX treatment as an }\end{array}$ \\
\hline
\end{tabular}




\section{Springer ongoing (Continued)}

effective, evidence-based treatment for opioid dependence for released HIV+ prisoners

\begin{tabular}{ll}
\hline Starting date & 2012 \\
\hline Contact information & Yale University \\
\hline Notes & \\
\hline
\end{tabular}

NTX: naltrexone 
DATA AND ANALYSES

Comparison 1. Therapeutic community

\begin{tabular}{lcccc} 
Outcome or subgroup title & $\begin{array}{c}\text { No. of } \\
\text { studies }\end{array}$ & $\begin{array}{c}\text { No. of } \\
\text { participants }\end{array}$ & Statistical method & Effect size \\
\hline 1 Criminal activity & 4 & Risk Ratio (M-H, Random, 95\% CI) & Totals not selected \\
1.1 Re-arrests & 2 & Risk Ratio (M-H, Random, 95\% CI) & $0.0[0.0,0.0]$ \\
1.2 Re-incarceration & 3 & Risk Ratio (M-H, Random, 95\% CI) & $0.0[0.0,0.0]$ \\
\hline
\end{tabular}

Comparison 2. Mental health court

\begin{tabular}{lcccc} 
Outcome or subgroup title & $\begin{array}{c}\text { No. of } \\
\text { studies }\end{array}$ & $\begin{array}{c}\text { No. of } \\
\text { participants }\end{array}$ & Statistical method & Effect size \\
\hline $\begin{array}{l}\text { 1 Self report dichotomous criminal } \\
\text { activity }\end{array}$ & 1 & & Risk Ratio (M-H, Random, 95\% CI) & Totals not selected \\
\hline
\end{tabular}

Comparison 3. Motivational interviewing and cognitive skills

\begin{tabular}{lclll} 
Outcome or subgroup title & $\begin{array}{c}\text { No. of } \\
\text { studies }\end{array}$ & $\begin{array}{c}\text { No. of } \\
\text { participants }\end{array}$ & Statistical method & Effect size \\
\hline 1 Self report drug use continuous & 1 & Mean Difference (IV, Random, 95\% CI) & Totals not selected \\
2 Self report drug use dichotomous & 1 & Risk Ratio (M-H, Random, 95\% CI) & Totals not selected \\
\hline
\end{tabular}

Comparison 4. Interpersonal psychotherapy

\begin{tabular}{lcccc} 
Outcome or subgroup title & $\begin{array}{c}\text { No. of } \\
\text { studies }\end{array}$ & $\begin{array}{c}\text { No. of } \\
\text { participants }\end{array}$ & Statistical method & Effect size \\
\hline 1 Self report drug use dichotomous & 1 & & Risk Ratio (M-H, Random, 95\% CI) & Totals not selected \\
\hline
\end{tabular}




\section{Analysis I.I. Comparison I Therapeutic community, Outcome I Criminal activity.}

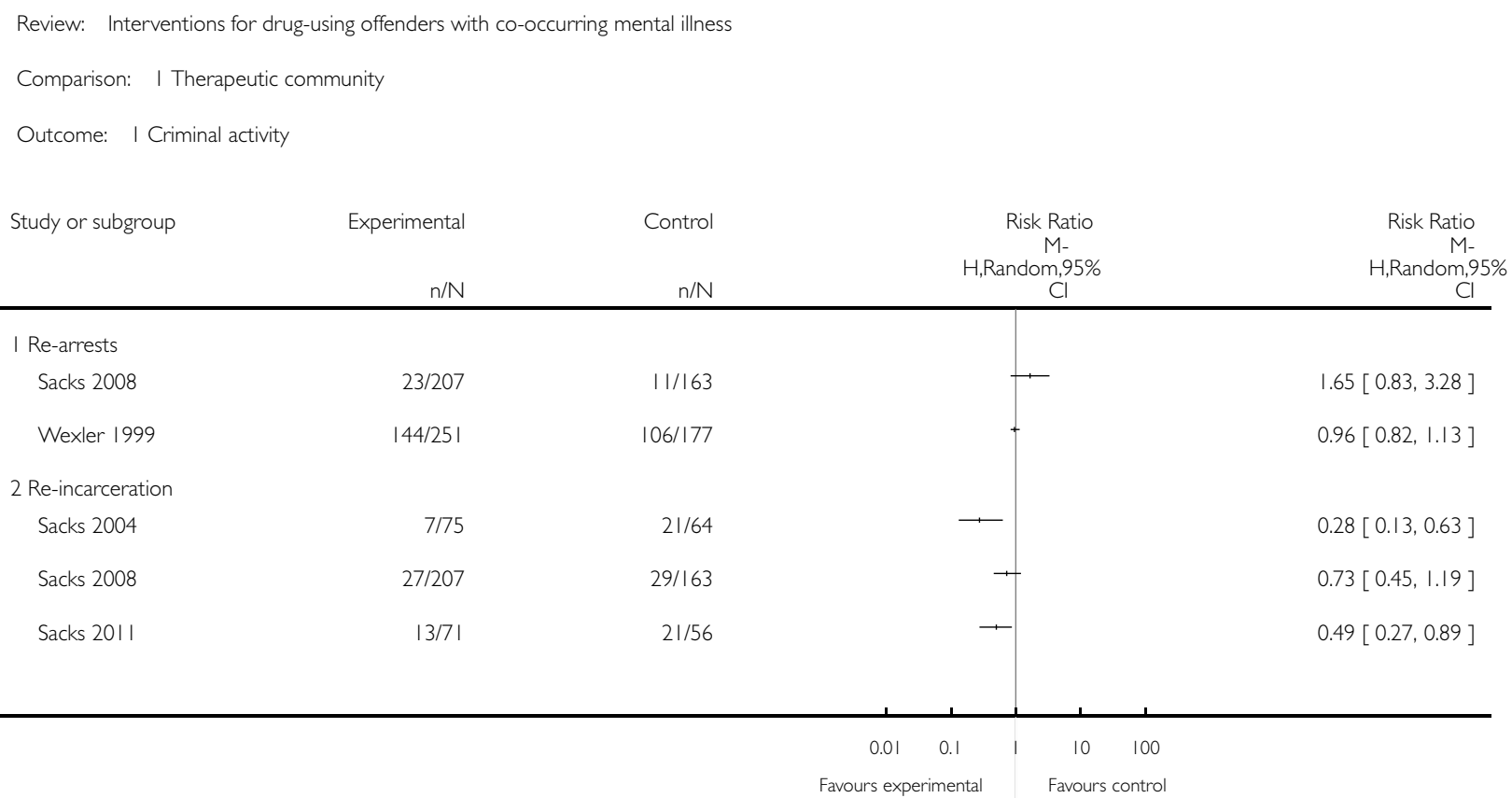

\section{Analysis 2.I. Comparison 2 Mental health court, Outcome I Self report dichotomous criminal activity.}

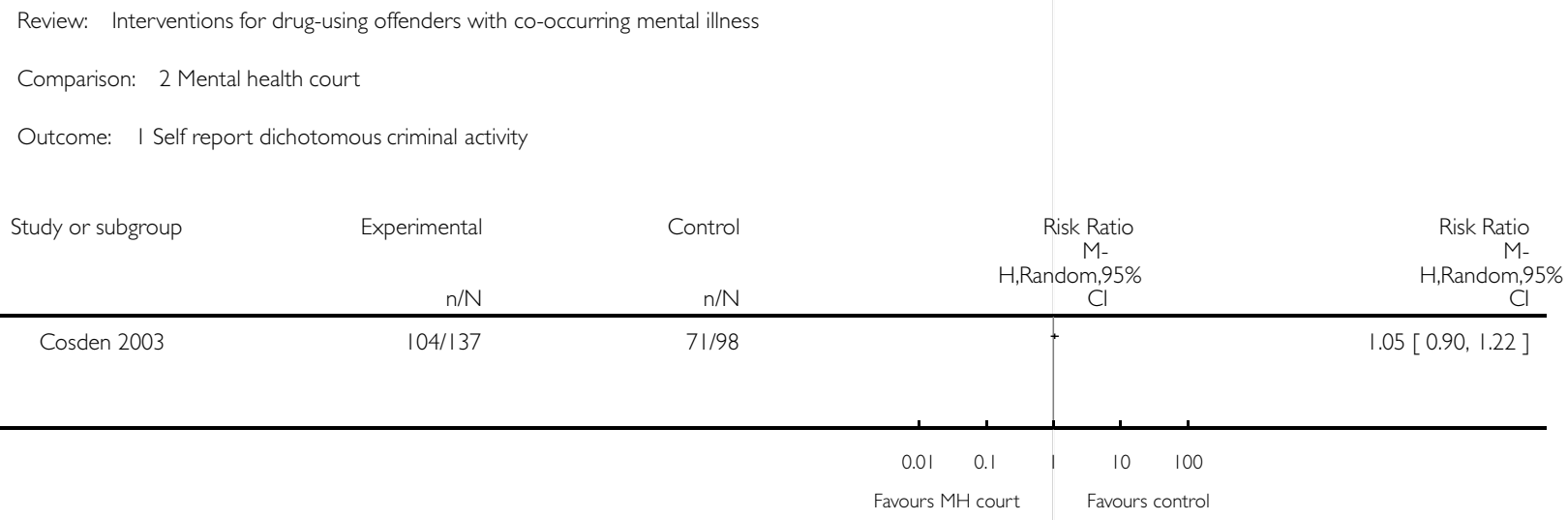




\section{Analysis 3.I. Comparison 3 Motivational interviewing and cognitive skills, Outcome I Self report drug use}

continuous.

Review: Interventions for drug-using offenders with co-occurring mental illness

Comparison: 3 Motivational interviewing and cognitive skills

Outcome: I Self report drug use continuous

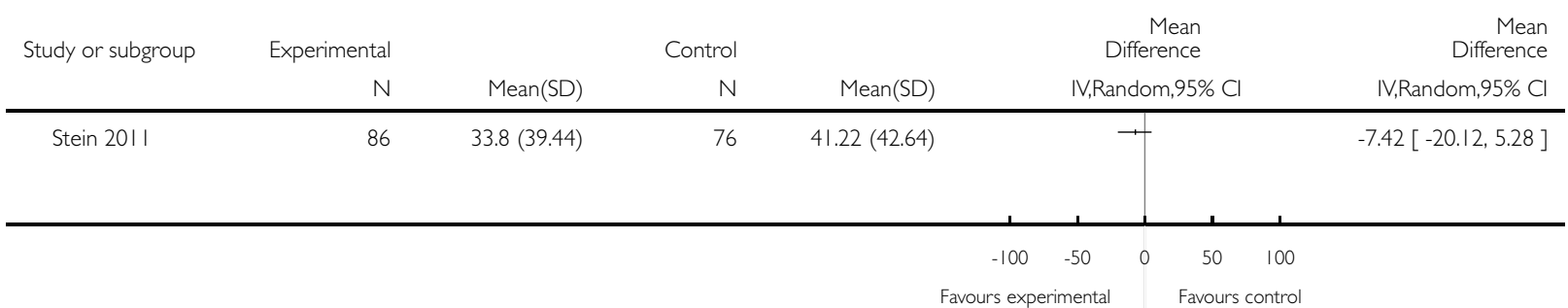

Analysis 3.2. Comparison 3 Motivational interviewing and cognitive skills, Outcome 2 Self report drug use dichotomous.

Review: Interventions for drug-using offenders with co-occurring mental illness

Comparison: 3 Motivational interviewing and cognitive skills

Outcome: 2 Self report drug use dichotomous

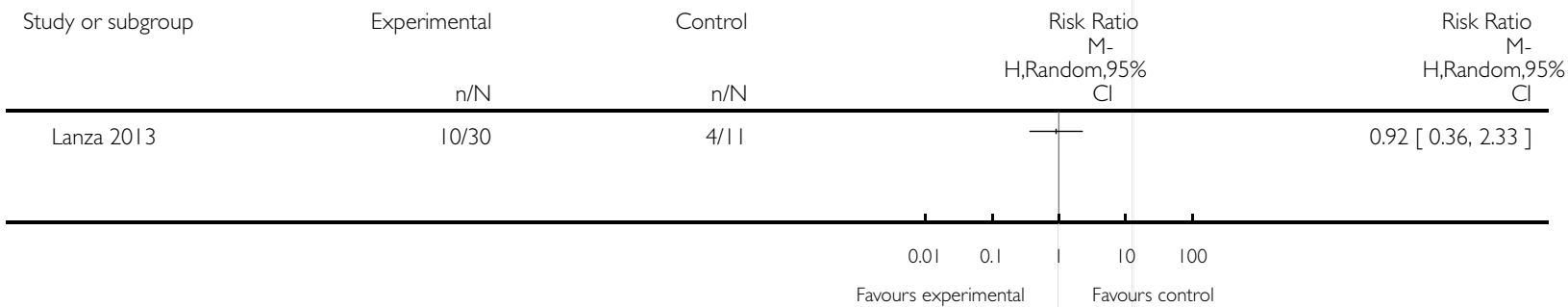




\section{Analysis 4.I. Comparison 4 Interpersonal psychotherapy, Outcome I Self report drug use dichotomous.}

\begin{tabular}{|c|c|c|c|c|}
\hline \multicolumn{5}{|c|}{ Comparison: 4 Interpersonal psychotherapy } \\
\hline \multicolumn{5}{|c|}{ Outcome: I Self report drug use dichotomous } \\
\hline Study or subgroup & Experimental & $\begin{array}{r}\text { Control } \\
n / N \\
\end{array}$ & $\begin{array}{c}\text { Risk Ratio } \\
\text { M- } \\
\text { H,Random,95\% } \\
\text { Cl }\end{array}$ & $\begin{array}{c}\text { Risk Ratio } \\
\text { M- } \\
\text { H,Random,95\% } \\
\text { Cl }\end{array}$ \\
\hline Johnson 2012 & $6 / 19$ & $9 / 19$ & $\longrightarrow$ & $0.67[0.30,1.50]$ \\
\hline
\end{tabular}

ADDITIONAL TABLES

Table 1. Mental health diagnoses

\begin{tabular}{|c|c|c|}
\hline Study, year & Criteria used for diagnoses & Description of mental health problem \\
\hline Cosden 2003 & $\begin{array}{l}\text { Determined by a psychiatrist/psychologist } \\
\text { on the basis of a clinical interview and ob- } \\
\text { servations }\end{array}$ & $\begin{array}{l}\text { Mood disorder } \\
\text { Schizophrenia } \\
\text { Bipolar disorder } \\
\text { Other } \\
\text { Dual diagnosis }\end{array}$ \\
\hline Johnson 2012 & $\begin{array}{l}\text { Hamilton Rating Scale for Depression } \\
\text { Median duration of index episode in } \\
\text { months } \\
\text { Number of depressive episodes } \\
\text { Number of previous suicide attempts } \\
\text { DSM-IV Axis I disorders using the SCID- } \\
\text { I/II. }\end{array}$ & $\begin{array}{l}\text { Criteria for a major depressive disorder at } \\
\text { least } 4 \text { weeks after substance abuse treat- } \\
\text { ment } \\
\text { Minimum score of } 18 \text { on the Hamilton } \\
\text { Rating Scale for Depression }\end{array}$ \\
\hline Lanza 2013 & $\begin{array}{l}\text { DSM-IV } \\
\text { Mini International Neuropsychiatric Inter- } \\
\text { view } \\
\text { Anxiety Sensitivity Index }\end{array}$ & $\begin{array}{l}\text { Anxiety } \\
\text { Mental health disorders } \\
\text { Antisocial personality disorder } \\
\text { Major depressive disorder } \\
\text { Generalised anxiety disorder }\end{array}$ \\
\hline Sacks 2004 & DIS & $\begin{array}{l}\text { Diagnoses of lifetime Axis I or Axis II men- } \\
\text { tal disorder } \\
\text { Antisocial personality disorder }\end{array}$ \\
\hline
\end{tabular}

Interventions for drug-using offenders with co-occurring mental illness (Review) 
Table 1. Mental health diagnoses (Continued)

\begin{tabular}{|c|c|c|}
\hline Sacks 2008 & $\begin{array}{l}\text { Global Severity Index } \\
\text { Beck Depression Inventory } \\
\text { Lifetime of mental health } \\
\text { PTSD Symptom Scale - Interview Post- } \\
\text { traumatic Stress Diagnostic Scale }\end{array}$ & $\begin{array}{l}\text { Depression } \\
\text { PTSD } \\
\text { Lifetime of mental health }\end{array}$ \\
\hline Sacks 2011 & $\begin{array}{l}\text { DSM-IV diagnostic criteria } \\
\text { Beck Depression Inventory } \\
\text { Post Traumatic Stress Disorder Symptom } \\
\text { Scale } \\
\text { Brief Symptom Inventory } \\
\text { Global Severity Index }\end{array}$ & $\begin{array}{l}\text { Depression } \\
\text { PTSD } \\
\text { Psychological distress }\end{array}$ \\
\hline Stein 2011 & CES-D Scale & $\begin{array}{l}\text { Scores }>16 \text { indicate presence of significant } \\
\text { depression. } 69.8 \% \text { had } \\
\text { significant depressive symptoms }\end{array}$ \\
\hline $\begin{array}{l}\text { Wexler 1999; } \\
\text { Prendergast 2003; Prendergast } 2004\end{array}$ & Not specified & $\begin{array}{l}\text { Antisocial personality disorder } \\
\text { Phobias } \\
\text { PTSD } \\
\text { Depression } \\
\text { Dysthymia } \\
\text { Attention deficit hyperactivity disorder }\end{array}$ \\
\hline
\end{tabular}

Table 2. Summary research evidence for the narrative synthesis

\begin{tabular}{|c|c|c|c|c|c|c|}
\hline Paper, year & Intervention & Comparison & Follow-up & Outcome type & Measurement & Actual outcome \\
\hline Cosden 2003 & $\begin{array}{l}\text { Sentencing } \\
\text { and case man- } \\
\text { agement (mental } \\
\text { health treatment } \\
\text { court and as- } \\
\text { sertive commu- } \\
\text { nity treat- } \\
\text { ment case man- } \\
\text { agement) }\end{array}$ & $\begin{array}{l}\text { Treatment as } \\
\text { usual }\end{array}$ & 6 and 12 months & $\begin{array}{l}\text { Criminal activity } \\
\text { dichotomous } \\
\text { Self report drug } \\
\text { use continuous }\end{array}$ & $\begin{array}{l}\% \text { and total } \\
\text { mean and SD }\end{array}$ & $\begin{array}{l}\% \text { arrested and } \\
\text { spent some time } \\
\text { in jail } \\
\% \text { convicted of a } \\
\text { new crime } \\
\text { Mean Addic- } \\
\text { tion Severity In- } \\
\text { dex (drug) com- } \\
\text { posite score }\end{array}$ \\
\hline $\begin{array}{l}\text { Wexler 1999; } \\
\text { Prendergast } \\
\text { 2003; } \\
\text { Prendergast } \\
2004\end{array}$ & $\begin{array}{l}\text { Ther- } \\
\text { apeutic commu- } \\
\text { nity, counselling } \\
\text { and aftercare }\end{array}$ & $\begin{array}{l}\text { Treatment as } \\
\text { usual and wait- } \\
\text { ing-list control }\end{array}$ & $\begin{array}{l}12, \quad 24, \quad 36 \\
\text { months } \\
\text { up to } 5 \text { years }\end{array}$ & $\begin{array}{l}\text { Biological drug } \\
\text { use dichotomous } \\
\text { Criminal activity } \\
\text { continuous } \\
\text { Criminal activity }\end{array}$ & $\begin{array}{l}\% \text { and total } \\
\text { mean and SD }\end{array}$ & $\begin{array}{l}\% \text { testing posi- } \\
\text { tive } \\
\text { for illicit drugs at } \\
12 \text { months' fol- } \\
\text { low-up }\end{array}$ \\
\hline
\end{tabular}

Interventions for drug-using offenders with co-occurring mental illness (Review)

Copyright (c) 2015 The Cochrane Collaboration. Published by John Wiley \& Sons, Ltd. 
Table 2. Summary research evidence for the narrative synthesis (Continued)

\begin{tabular}{|c|c|c|c|c|c|c|}
\hline & & & & $\begin{array}{l}\text { dichotomous } \\
\text { Self report drug } \\
\text { use dichotomous }\end{array}$ & & $\begin{array}{l}\text { Mean } \\
\text { months incarcer- } \\
\text { ated in the year } \\
\text { following release } \\
\% \text { any arrest } \\
\% \text { arrested for } \\
\text { drug crime } \\
\% \text { arrested for } \\
\text { property crime } \\
\% \text { arrested for vi- } \\
\text { olent crime } \\
\% \text { arrested for } \\
\text { other crime } \\
\% \text { used drugs } \\
\text { heavily in past } \\
\text { year at } 5 \text { years } \\
\text { Mean days until } \\
\text { re-incarceration } \\
\% \\
\text { incarcerated re- } \\
\text { Mean days on } \\
\text { parole to first re- } \\
\text { turn to custody } \\
\% \text { returned to } \\
\text { prison within } 3 \\
\text { years post- parole }\end{array}$ \\
\hline Sacks 2004 & $\begin{array}{l}\text { Modified thera- } \\
\text { peutic commu- } \\
\text { nity (Per- } \\
\text { sonal Reflections } \\
\text { therapeutic com- } \\
\text { munity and vol- } \\
\text { untary residen- } \\
\text { tial aftercare) }\end{array}$ & $\begin{array}{l}\text { Intensive psychi- } \\
\text { atric services }\end{array}$ & 12 months & $\begin{array}{l}\text { Criminal activity } \\
\text { continuous } \\
\text { Criminal activity } \\
\text { dichotomous } \\
\text { Self report drug } \\
\text { use dichotomous }\end{array}$ & $\begin{array}{l}\text { Mean and SD } \\
\% \text { and total }\end{array}$ & $\begin{array}{l}\text { Mean number of } \\
\text { days until incar- } \\
\text { ceration } \\
\text { Mean number of } \\
\text { days until first } \\
\text { crime } \\
\% \text { re-incarcera- } \\
\text { tion } \\
\% \text { criminal activ- } \\
\text { ity } \\
\% \text { alcohol/drug } \\
\text { offence } \\
\% \text { other (non- } \\
\text { alcohol/drug) of- } \\
\text { fence } \\
\% \text { illegal drug } \\
\text { use }\end{array}$ \\
\hline Sacks 2011 & $\begin{array}{l}\text { Therapeutic } \\
\text { community (re- } \\
\text { entry modified) }\end{array}$ & $\begin{array}{l}\text { Parole super- } \\
\text { vision case man- } \\
\text { agement }\end{array}$ & 12 months & $\begin{array}{l}\text { Criminal activity } \\
\text { dichotomous }\end{array}$ & $\%$ with total & $\begin{array}{l}\% \quad \text { re- } \\
\text { incarcerated } \\
\% \text { self reported } \\
\text { criminal activity }\end{array}$ \\
\hline
\end{tabular}

Interventions for drug-using offenders with co-occurring mental illness (Review)

Copyright @ 2015 The Cochrane Collaboration. Published by John Wiley \& Sons, Ltd. 
Table 2. Summary research evidence for the narrative synthesis (Continued)

\begin{tabular}{|c|c|c|c|c|c|c|}
\hline Sacks 2008 & $\begin{array}{l}\text { Therapeutic } \\
\text { community }\end{array}$ & $\begin{array}{l}\text { Cogni- } \\
\text { tive behavioural } \\
\text { therapy }\end{array}$ & 6 and 12 months & $\begin{array}{l}\text { Criminal activity } \\
\text { dichotomous } \\
\text { Criminal activity } \\
\text { self report and } \\
\text { official } \\
\text { Self report drug } \\
\text { use }\end{array}$ & $\%$ with total & $\begin{array}{l}\text { Criminal activ- } \\
\text { ity, arrest, } \\
\text { and drug- related } \\
\text { activity (self-re- } \\
\text { ported) } \\
\text { Criminal record } \\
\text { data (\% incarcer- } \\
\text { ated, mean days } \\
\text { to incarceration) } \\
\% \text { self-reported } \\
\text { illegal drug use }\end{array}$ \\
\hline Johnson 2012 & $\begin{array}{l}\text { Interpersonal } \\
\text { psychotherapy }\end{array}$ & $\begin{array}{l}\text { psycho- } \\
\text { educational }\end{array}$ & 3 months & $\begin{array}{l}\text { biological drug } \\
\text { use }\end{array}$ & $\%$ with total & $\begin{array}{l}\text { Relapse within } \\
3 \text { - month follow- } \\
\text { up period, de- } \\
\text { fined as using } \\
\text { drugs on at least } \\
10 \% \text { of non-in- } \\
\text { carcerated days } \\
\text { or any positive } \\
\text { breath test/urine } \\
\text { drug screen }\end{array}$ \\
\hline Lanza 2013 & $\begin{array}{l}\text { Cogni- } \\
\text { tive behavioural } \\
\text { therapy and ac- } \\
\text { cep- } \\
\text { tance and com- } \\
\text { mitment therapy }\end{array}$ & control group & 3 months & $\begin{array}{l}\text { Self report drug } \\
\text { use dichotomous }\end{array}$ & $\%$ and total & $\begin{array}{l}\text { Self report, cor- } \\
\text { roborated by uri- } \\
\text { nalysis }\end{array}$ \\
\hline $\begin{array}{l}\text { Stein } 2011 \text { (high } \\
\text { depression score) }\end{array}$ & $\begin{array}{l}\text { Motivational in- } \\
\text { terviewing }\end{array}$ & $\begin{array}{l}\text { Relaxation train- } \\
\text { ing }\end{array}$ & 3 months & $\begin{array}{l}\text { Self report drug } \\
\text { use continuous }\end{array}$ & Mean and SD & $\begin{array}{l}\text { Mean joints per } \\
\text { day } \\
\text { Mean \% days } \\
\text { used marijuana }\end{array}$ \\
\hline
\end{tabular}


A P P E N DICES

\section{Appendix I. Cochrane Central Register of Controlled Trials (CENTRAL) search strategy}

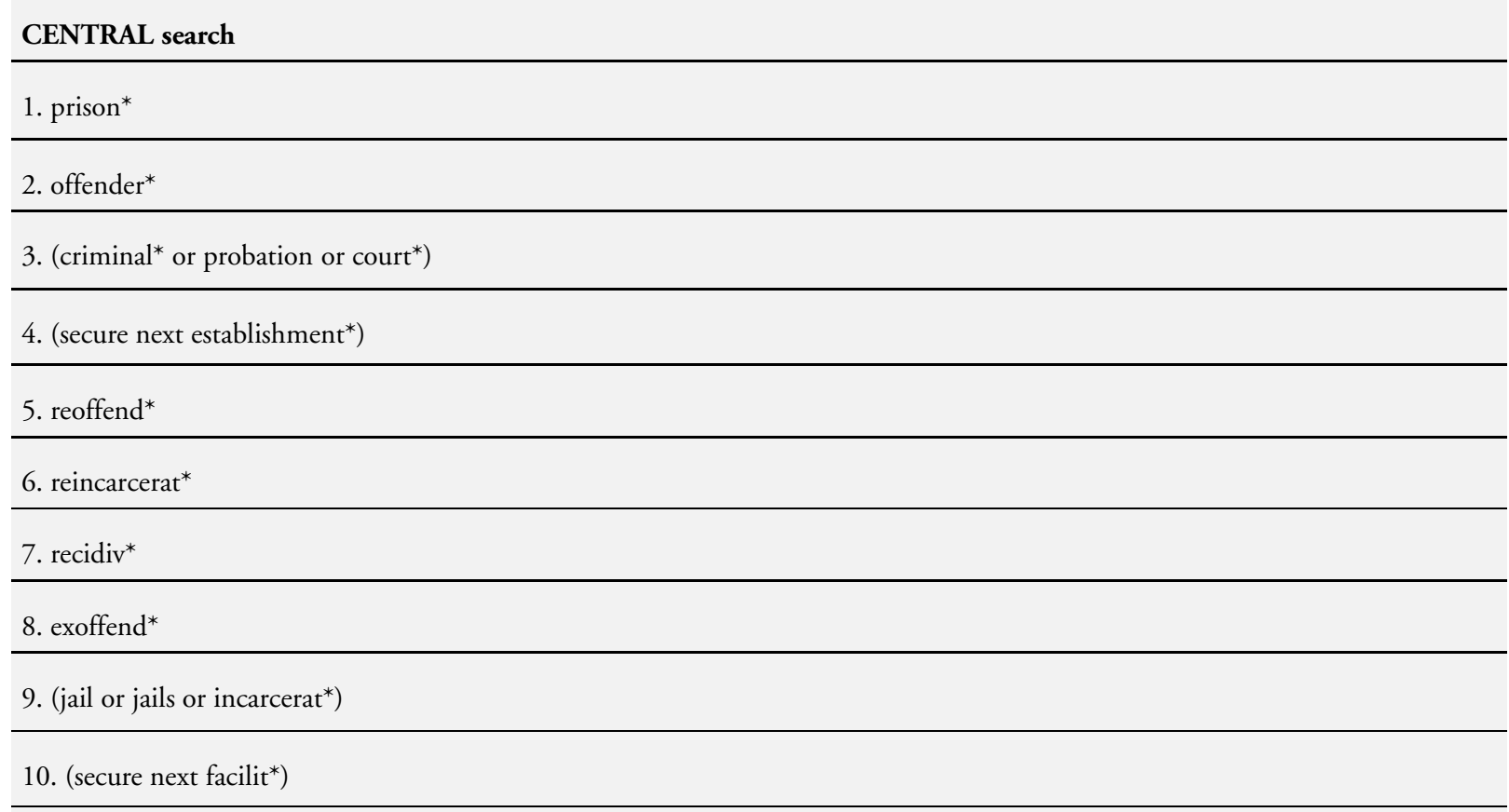

11. (convict* or revocation or inmate* or (high next security))

12. PRISONERS

13. LAW ENFORCEMENT

14. JURISPRUDENCE

15. CRIME

$16 . \# 1$ or $\# 2$ or $\# 3$ or $\# 4$ or $\# 5$ or $\# 6$ or $\# 7$ or $\# 8$ or $\# 9$ or $\# 10$ or $\# 11$ or $\# 12$ or $\# 13$ or $\# 14$ or \#15

17. SUBSTANCE-RELATED DISORDERS

18. ((substance or drug*) next (abuse* or misuse* or dependen* or use* or addict $\left.\left.{ }^{*}\right)\right)$

19. (narcotics or chemical or opiate) next (dependen* or addict* or abuse* or misuse*))

20. ((heroin) next (addict* or dependen* or misuse* or abuse*))

21. ((crack) next (addict* or dependen* $^{*}$ or misuse* or abuse* or use $\left.^{*}\right)$ )

22. ((cocaine next addict*) or (cocaine next dependenc*) or (cocaine next misuse*) or (cocaine next abuse*) or (cocaine next use $\left.{ }^{*}\right)$ ) 
(Continued)

23. ((amphetamine* $\left.{ }^{*}\right)$ next (addict* or dependen* $^{*}$ or misuse* or abuse* or use* $\left.{ }^{*}\right)$

24. (addicts or (dependence next disorder) or (drug next involved))

25. (street next drugs)

26. STREET DRUGS

27. DESIGNER DRUGS

28. NARCOTICS

29. COCAINE

30. AMPHETAMINES

31. ANALGESICS ADDICTIVE

32. ANALGESICS OPIOID

33. PSYCHOTROPIC DRUGS

34. opioid* or opiat*

$35 . \# 17$ or $\# 18$ or $\# 19$ or $\# 20$ or $\# 21$ or $\# 22$ or $\# 23$ or $\# 24$ or $\# 25$ or $\# 26$ or $\# 27$ or $\# 28$ or $\# 29$ or $\# 30$ or $\# 31$ or \#32 or \#33 or \#34

35. (\#16 and \#35)

\section{Appendix 2. MEDLINE search strategy}

\section{MEDLINE search}

1. exp "Substance-Related-Disorders"/

2. ((drug or substance) adj (abuse* or addict* or dependen* or misuse*)).ti,ab

3. (drug* adj (treat* or intervention* or program*)

4. substance near (treat* or intervention* or program*)

5. (detox* or methadone) in ti,ab

6. narcotic ${ }^{*}$ near (treat* ${ }^{*}$ or intervention* ${ }^{*}$ or program*)

7. 1 or 2 or 3 or 4 or 5 or 6

Copyright $\odot 2015$ The Cochrane Collaboration. Published by John Wiley \& Sons, Ltd. 


\section{(Continued)}

8. prison*. ti,ab

9. exp "Prisoners"/

10. offender* or criminal* or inmate* or convict* or probation* or remand or felon*).ti,ab

11. exp "Prisons"/

12. 8 or 9 or 10 or 11

13.7 and 12

\section{Appendix 3. EMBASE search strategy}

\section{EMBASE search}

1. (detox $\$$ or methadone or antagonist prescri $\$) . t i, a b$.

2. detoxification/ or drug detoxification/ or drug withdrawal/ or drug dependence treatment/ or methadone/ or methadone treatment/ or diamorphine/ or naltrexone/

3. (diamorphine or naltrexone or therapeutic communit\$).ti,ab

4. morality/

5. (motivational interview\$ or motivational enhancement).ti,ab

6. (counselling or counseling).ti,ab.

7. exp counseling/

8. (psychotherap\$ or cognitive behavioral or cognitive behavioural).ti,ab

9. exp psychotherapy/

10. (moral adj3 training).ti,ab.

11. (cognitive restructuring or assertiveness training).ti,ab

12. reinforcement/ or self monitoring/ or self control/

13. (relaxation training or rational emotive or family relationship therap\$).ti,ab

14. social learning/ or withdrawal syndrome/ or coping behavior/ 


\section{(Continued)}

15. (community reinforcement or self monitoring or self control or self management or interpersonal skills).ti,ab

16. (goal\$ adj3 setting).ti,ab.

17. (social skills adj3 training).ti,ab.

18. anger/ or lifestyle/

19. (basic skills adj3 training).ti,ab.

20. (relapse adj3 prevent $\$$ ).ti,ab.

21. (craving adj3 (minimi $\$$ or reduc $\$))$.ti,ab.

22. (trigger or triggers or coping skills or anger management or group work).ti,ab

23. (lifestyle adj3 modifi).ti,ab.

24. (high intensity training or resettlement or throughcare or aftercare or after care).ti,ab

25. aftercare/ or halfway house/

26. (brief solution or brief intervention $\$$ or minnesota program $\$$ or 12 step $\$$ or twelve step\$).ti,ab

27. (needle exchange or nes or syringe exchange or dual diagnosis or narcotics anonymous).ti,ab

28. self help/ or support group/

29. (self-help or selfhelp or self help or outreach or bail support or arrest referral\$).ti,ab

30. exp urinalysis/ or rehabilitation/ or rehabilitation center/

31. (diversion or dtto or dttos or drug treatment or testing order $\$$ or carat or carats).ti,ab

32. (combined orders or drug-free or drug free).ti,ab.

33. (peer support or evaluation\$ or urinalysis or drug testing or drug test or drug tests).ti,ab

34. ((rehab or rehabilitation or residential or discrete) adj2 (service\$ or program\$)).ti,ab

35. (asro or addressing substance $\$$ or pasro or prisons addressing or acupuncture or shock or boot camp or boot camps).ti,ab

36. (work ethic camp\$ or drug education or tasc or treatment accountability).ti,ab

37. exp acupuncture/

Interventions for drug-using offenders with co-occurring mental illness (Review) 


\section{(Continued)}

\section{8. or/1-36}

39. (remand or prison or prisoner or prisoners or offender $\$$ or criminal $\$$ or probation or court or courts).ti,ab

40. (secure establishment $\$$ or secure facilit\$).ti,ab.

41. (reoffend $\$$ or reincarcerat $\$$ or recidivi $\$$ or ex-offender $\$$ or jail or jails or goal or goals).ti,ab

42. (incarcerat $\$$ or convict or convicts or convicted or felon or felons or conviction\$ or revocation or inmate $\$$ or high security).ti,ab

43. criminal justice/ or custody/ or detention/ or prison/ or prisoner/ or offender/ or probation/ or court/ or recidivism/ or crime/ or criminal behavior/ or punishment/

44. or/39-43

45.38 and 44

46. (substance abuse\$ or substance misuse $\$$ or substance use $\$$ ).ti,ab

47. (drug dependanc\$ or drug abuse $\$$ or drug use $\$$ or drug misuse $\$$ or drug addict $\$$ ).ti,ab

48. (narcotics adj3 (addict\$ or use\$ or misuse\$ or abuse $\$)$ ).ti,ab

49. (chemical dependanc $\$$ or opiates or heroin or crack or cocaine or amphetamines or addiction or dependance disorder or drug involved).ti,ab

50. substance abuse/ or drug abuse/ or analgesic agent abuse/ or drug abuse pattern/ or drug misuse/ or intravenous drug abuse/ or multiple drug abuse/

51. addiction/ or drug dependence/ or narcotic dependence/ or exp narcotic agent/ or narcotic analgesic agent/

52. opiate addiction/ or heroin dependence/ or morphine addiction/

53. cocaine/ or amphetamine derivative/ or psychotropic agent/

54. or $/ 46-53$

55.45 and 54 


\section{Appendix 4. PsycINFO search strategy}

\section{PsycINFO}

1. (detoxification in de) or (drug withdrawal in de)

2. (drug usage screening in de) or (methadone maintenance) in de

3. explode "Narcotic-Antagonists" in DE

4. 1 or 2 or 3

5. (counseling in de) or (explode "psychotherapeutic-counseling" in de)

6. (explode "cognitive-therapy" in de) or (explode "psychotherapeutic-techniques" in de)

7. (cognitive restructuring in de) or (assertiveness training in de)

8. explode "relaxation-therapy" in de

9. (rational emotive therapy in de) or (rational-emotive therapy in de)

10. (explode "self monitoring" in de) or (explode self-monitoring) in de

11. (goal setting in de) or (self control in de) or (explode "self-management" in de)

12. (social skills in de) or (relapse prevention in de) or (craving in de) or (coping behavior in de)

13. (anger control in de) or (explode "group-psychotherapy" in de) or (brief psychotherapy in de)

14. (explode "behavior-modification" in de) or (posttreatment followup in de) or (aftercare in de)

15. (halfway houses in de) or (twelve step programs in de)

16. (dual diagnoses in de) or (explode "self help techniques" in de) or (outreach programs in de) or (court referrals in de)

17. (peer pressure in de) or (urinalysis in de)

18. (drug rehabilitation in de) or (residential care institutions in de) or (acupuncture in de) or (drug education in de)

19. (detox* or methadone or antagonist prescri* or diamorphine or naltrexone or therapeutic communit*) in ti,ab

20. (motivational interview* or motivational enhancemen* or counseling or psychotherapy or psychotherapies) in ti,ab

21. (cognitive behav* or cognitive therapy or cognitive therapies or moral training or cognitive restructuring) in ti,ab

22. (assertiveness training or relaxation training or relaxation therapy or relaxation therapies) in ti,ab 


\section{(Continued)}

23. (rational emotive therap* or rational emotive behav* therap* or family relationship therap* or community reinforcement) in ti,ab

24. (self-monitor* or self monitor* or goal setting or self control or self-control or self management or self-management) in ti,ab

25. (interpersonal skills training or social skills training or basic skills training) in ti,ab

26. (relapse with prevent*) in ti,ab

27. (craving near reduc*) in ti,ab

28. craving with (reduc* in ti,ab)

29. (trigger* or coping skills or anger management or group work or lifestyle modif* or high intensity training or resettlement) in ti, $\mathrm{ab}$

30. (throughcare or aftercare or after care or brief solution* or brief intervention*) in ti,ab

31. (minnesota or 12 step* $^{*}$ or twelve step* or needle exchange or nes or syringe exchange or dual diagnosis) in ti,ab

32. (narcotics anonymous or self-help or self help or outreach or bail support or arrest referral*) in ti,ab

33. (diversion or dtto* or testing order* or carat* or counseling assessment referral or combined order or combined orders or drug free wing* or drug free environment*) in ti,ab

34. (peer support or user evaluations or urinalysis or urinalyses or mandatory drug test* or rehabilitation or discrete service* or discrete program $\left.^{*}\right)$ in ti,ab

35. (residential program* or residential scheme* or asro or addressing substance* or pasro or prisons addressing substance) in ti,ab

36. (acupuncture or shock or boot camp* or work ethic or drug education or tasc or treatment accountability) in ti,ab

37. or/4-36

38. (secure facilities or convict* or revocation or inmate* or high security) in ti,ab

39. (prisoners in de) or (explode "correctional-institutions" in de)

40. (perpetrators in de) or (explode criminals in de)

41. (probation in de) or (parole in de) or (incarceration in de) or (recidivism in de) or (criminal conviction in de) or (crime in de)

42. (remand or prison* or offender* or criminal* or probation or court or courts or secure establishment* or reoffend* or reincarcerat* or recidivi* or ex-offender* or jail or jails or incarcerat*) in ti,ab

43. (drug abuse in de) or (explode "inhalant-abuse" in de) or (explode "drug-dependency" in de)

44. (polydrug abuse in de) or (drug abuse in de) or (intravenous drug usage in de)

Interventions for drug-using offenders with co-occurring mental illness (Review) 
(Continued)

45. (narcotic drugs in de) or (heroin in de) or (cocaine in de) or (explode amphetamine in de)

46. (substance abuse* or substance misuse* or substance user*) in ti,ab

47. (drug dependen* or drug abuse* or drug misuse* or drug addict* or drug use) in ti,ab

48. (narcotic abuse* or narcotic misuse* or chemical dependen* or opiate misuse* or opiate abuse*) in ti,ab

49. (heroin use* or heroin addict* or heroin misuse* or heroin abuse*) in ti,ab

50. (crack use* or crack addict* or crack misuse* or crack abuse*) in ti,ab

51. (cocaine use* or cocaine addict* ${ }^{*}$ cocaine misuse* or cocaine abuse*) in ti,ab

52. (amphetamine* use $^{*}$ or amphetamine* addict* $^{*}$ or amphetamine* misuse* or amphetamine* abuse*) in ti,ab

53. (dependence disorder or drug involved or dug-involved) in ti,ab

54. \#38 or \#39 or \#40 or \#41 or \#42

$55 . \# 4$ or \#43 or \#44 or \#45 or \#46 or \#47 or \#48 or \#49 or \#50 or \#51 or \#52 or \#53

56. \#37 and \#54 and \#55

Appendix 5. PASCAL, SciSearch, Social SciSearch, Wilson Applied Science and Technology Abstracts search strategy

PASCAL search

1. (DETOX? OR METHADONE OR ANTAGONIST()PRESCRI?)/TI,AB

2. METHADONE/DE OR NALTREXONE/DE

3. (DIAMORPHINE OR NALTREXONE)/TI,AB

4. THERAPEUTIC()COMMUNITY/DE OR THERAPEUTIC()COMMUNIT?)/TI,AB

5. (MOTIVATIONAL()INTERVIEW? OR MOTIVATIONAL()ENHANCEMENT)/TI,AB

6. (COUNSELLING OR COUNSELING)/TI,AB

7. COUNSELING/DE

8. (PSYCHOTHERAP? OR COGNITIVE()BEHAVIORAL OR COGNITIVE()BEHAVIOURAL)/TI,AB

Interventions for drug-using offenders with co-occurring mental illness (Review)

Copyright (C) 2015 The Cochrane Collaboration. Published by John Wiley \& Sons, Ltd. 
(Continued)

9. PSYCHOTHERAPY!/DE

10. (MORAL(3W)TRAINING)/TI,AB

11. (COGNITIVE()RESTRUCTURING OR ASSERTIVENESS()TRAINING)/TI,AB

12. ASSERTIVENESS/DE OR RELAXATION()TECHNIQUES/DE

13. (RELAXATION()TRAINING OR RATIONAL()EMOTIVE OR FAMILY()RELATIONSHIP()THERAP?)/TI,AB

\section{FAMILY()RELATIONS/DE}

15. (COMMUNITY()REINFORCEMENT OR SELF()MONITORING OR SELF()CONTROL OR SELF()MANAGEMENT OR INTERPERSONAL()SKILLS)/TI,AB

16. (GOAL?(3W)SETTING)/TI,AB

17. (SOCIAL(3W)TRAINING)/TI,AB

18. SOCIAL RESPONSIBILITY/DE

19. (BASIC()SKILLS(3W)TRAINING)/TI,AB

20. (RELAPSE(3W)PREVENT?)/TI,AB

21. (CRAVING(3W)(MINIMI? OR REDUC?))/TI,AB

22. (TRIGGER OR TRIGGERS OR COPING()SKILLS OR ANGER()MANAGEMENT OR GROUP()WORK)/TI,AB

23. (LIFESTYLE(3W)MODIFI?)/TI,AB

24. (HIGH()INTENSITY()TRAINING OR RESETTLEMENT OR THROUGHCARE OR AFTERCARE OR AFTER()CARE) $/ \mathrm{TI}, \mathrm{AB}$

25. ADAPTATION,-PSYCHOLOGICAL!/DE OR ANGER/DE OR LIFE()STYLE/DE OR AFTER()CARE/DE OR HALFWAY ()HOUSES/DE

26. (BRIEF()SOLUTION OR BRIEF()INTERVENTION? OR MINNESOTA()PROGRAM? OR 12()STEP? OR TWELVE() $\mathrm{STEP}$ )/TI,AB

27. (NEEDLE()EXCHANGE OR NES OR SYRINGE()EXCHANGE OR DUAL()DIAGNOSIS OR NARCOTICS()ANONYMOUS)/TI,AB

28. NEEDLE-EXCHANGE()PROGRAMS/DE

29. (SELF-HELP OR SELFHELP OR SELF()HELP OR OUTREACH OR BAIL()SUPPORT OR ARREST()REFERRAL?)/TI, $\mathrm{AB}$

30. SELF-HELP()GROUPS/DE OR URINALYSIS/DE OR SUBSTANCE()ABUSE()DETECTION/DE 
(Continued)

31. (DIVERSION OR DTTO OR DTTOS OR DRUG()TREATMENT OR TESTING()ORDER? ? OR CARAT OR CARATS) /TI,AB

32. (COMBINED()ORDERS OR DRUG-FREE OR DRUG()FREE)/TI,AB

33. (PEER()SUPPORT OR EVALUATION? ? OR URINALYSIS OR DRUG()TESTING OR DRUG()TEST? ?)/TI,AB

34. ((REHAB OR REHABILITATION OR RESIDENTIAL OR DISCRETE)(2W)(SERVICE? ? OR PROGRAM?))/TI,AB

35. (ASRO OR ADDRESSING()SUBSTANCE? OR PASRO OR PRISONS()ADDRESSING OR ACUPUNCTURE OR SHOCK OR BOOT()CAMP OR BOOT()CAMPS)/TI,AB

36. (WORK()ETHIC()CAMP? ? OR DRUG()EDUCATION OR TASC OR TREATMENT()ACCOUNTABILITY)/TI,AB

37. ACUPUNCTURE-THERAPY!/DE OR ACUPUNCTURE/DE OR HEALTH()EDUCATION/DE OR SUBSTANCE() ABUSE()TREATMENT()CENTERS/DE

38. $\mathrm{S} 1: \mathrm{S3}$

39. $S 4: S 37$

40. S38 AND S39

40. (REMAND OR PRISON OR PRISONER OR PRISONERS OR OFFENDER? ? OR CRIMINAL? ? OR PROBATION OR COURT OR COURTS)/TI,AB

41. (SECURE()ESTABLISHMENT? ? OR SECURE()FACILIT?)/TI,AB

42. (REOFFEND? OR REINCARCERAT? OR RECIDIVI? OR EX()OFFENDER? ? OR JAIL OR JAILS)/TI,AB

43. (INCARCERAT? OR CONVICT OR CONVICTS OR CONVICTED OR FELON? ? OR CONVICTION? ? OR REVOCATION OR INMATE? ? OR HIGH()SECURITY)/TI,AB

44. PRISONERS/DE OR LAW()ENFORCEMENT/DE OR JURISPRUDENCE/DE

45. S40:S44

46. S40 AND S45

47. (SUBSTANCE()ABUSE? OR SUBSTANCE()MISUSE? OR SUBSTANCE()USE?)/TI,AB

48. (DRUG()DEPENDANC? OR DRUG()ABUSE? OR DRUG()USE? OR DRUG()MISUSE? OR DRUG()ADDICT?)/TI,AB

49. (NARCOTICS(3W)(ADDICT? OR USE? OR MISUSE? OR ABUSE?))/TI,AB

50. (CHEMICAL()DEPENDANC? OR OPIATES OR HEROIN OR CRACK OR COCAINE OR AMPHETAMINES OR ADDICTION OR DEPENDENCE()DISORDER OR DRUG()INVOLVED)/TI,AB

Interventions for drug-using offenders with co-occurring mental illness (Review) 
51. SUBSTANCE-RELATED()DISORDERS/DE OR AMPHETAMINE-RELATED()DISORDERS/DE OR COCAINE-RELATED()DISORDERS/DE OR MARIJUANA ()ABUSE/DE

52. OPIOID-RELATED-DISORDERS!/DE OR PHENCYCLIDINE()ABUSE/DE OR SUBSTANCE()ABUSE()INTRAVENOUS/DE

53. STREET()DRUGS/DE OR DESIGNER()DRUGS/DE OR NARCOTICS/DE

54. COCAINE!/DE OR AMPHETAMINES!/DE OR ANALGESICS()OPIOID/DE

55. S47:S54

56. S46 AND S55

57. (DETOXIFICATION OR METHADONE OR ANTAGONIST-PRESCRIBING)/DE FROM 144,34,434,7,99,65,35,6

58. (DIAMORPHINE OR NALTREXONE)/DE FROM 144,34,434,7,99,65,35,6

59. THERAPEUTIC-COMMUNITY)/DE FROM 144,34,434,7,99,65,35,6

60. (MOTIVATIONAL-INTERVIEW OR MOTIVATIONAL-ENHANCEMENT)/DE FROM 144,34,434,7,99,65,35,6

61. (COUNSELLING OR COUNSELING)/DE FROM 144,34,434,7,99,65,35,6

62. (PSYCHOTHERAPY! OR COGNITIVE-BEHAVIORAL OR COGNITIVE-BEHAVIOURAL)/DE FROM 144,34,434,7, $99,65,35,6$

63. (MORAL-TRAINING)/DE FROM 144,34,434,7,99,65,35,6

64. (COGNITIVE-RESTRUCTURING OR ASSERTIVENESS-TRAINING)/DE FROM 144,34,434,7,99,65,35,6

65. (RELAXATION-TRAINING OR RATIONAL-EMOTIVE OR FAMILY-RELATIONSHIP-THERAPY)/DE FROM 144,34, $434,7,99,65,35,6$

66. FAMILY-RELATIONS/DE

67. (COMMUNITY-REINFORCEMENT OR SELF-MONITORING OR SELF-CONTROL OR SELF-MANAGEMENT OR INTERPERSONAL-SKILLS)/DE FROM 44,34,434,7,99,65,35,6

68. (GOAL-SETTING)/DE FROM 144,34,434,7,99,65,35,6

69. (SOCIAL-SKILLS-TRAINING)/DE FROM 144,34,434,7,99,65,35,6

70. SOCIAL-RESPONSIBILITY/DE

71. (BASIC-SKILLS-TRAINING)/DE FROM 144,34,434,7,99,65,35,6

72. (RELAPSE-PREVENTION)/DE FROM 144,34,434,7,99,65,35,6 
74. (TRIGGER OR COPING-SKILLS OR ANGER-MANAGEMENT OR GROUP-WORK)/DE FROM 144,34,434,7,99,65, 35,6

75. (LIFESTYLE-MODIFICATION)/DE FROM 144,34,434,7,99,65,35,6

76. (HIGH-INTENSITY-TRAINING OR RESETTLEMENT OR THROUGHCARE OR AFTERCARE OR AFTER-CARE)/ DE FROM 144,34,434,7,99,65,35,6

77. (BRIEF-SOLUTION OR BRIEF-INTERVENTIONS OR MINNESOTA-PROGRAM OR 12-STEP-PROGRAM OR TWELVE-STEP-PROGRAM)/DE FROM 144,34,434,7,99,65,35,6

77. (NEEDLE-EXCHANGE OR SYRINGE-EXCHANGE OR DUAL-DIAGNOSIS OR NARCOTICS-ANONYMOUS)/DE FROM 144,34,434,7,99,65,35,6

79. (SELF-HELP OR OUTREACH OR BAIL-SUPPORT OR ARREST-REFERRAL)/DE FROM 144,34,434,7,99,65,35,6

80. (DRUG-TREATMENT OR TESTING-ORDERS OR CARAT)/DE FROM 144,34,434,7,99,65,35,6

81. (COMBINED-ORDERS OR DRUG-FREE)/DE FROM 144,34,434,7,99,65,35,6

82. (PEER-SUPPORT OR EVALUATION OR URINALYSIS OR DRUG-TESTING OR DRUG-TESTS)/DE FROM 144,34, $434,7,99,65,35,6$

83. (REHABILITATION OR RESIDENTIAL OR DISCRETE-SERVICES)/DE FROM 144,34,434,7,99,65,35,6

84. (ASRO OR PASRO ACUPUNCTURE OR BOOT-CAMP)/DE FROM 144,34,434,7,99,65,35,6

85. (WORK-ETHIC-CAMP OR DRUG-EDUCATION OR TASC OR TREATMENT-ACCOUNTABILITY)/DE FROM 144, $34,434,7,99,65,35,6$

86. (REMAND OR PRISON OR PRISONER OR PRISONERS OR OFFENDER OR OFFENDERS OR CRIMINAL OR CRIMINALS OR PROBATION OR COURT OR COURTS)/DE FROM 144,34,434,7,99,65,35,6

87. (SECURE-ESTABLISHMENTS OR SECURE-FACILITY)/DE FROM 144,34,434,7,99,65,35,6

88. (REOFFENDERS OR REINCARCERATION OR RECIDIVISM OR EX-OFFENDERS OR JAILS)/DE FROM 144,34, $434,7,99,65,35,6$

89. (INCARCERATION OR CONVICT OR CONVICTS OR FELON OR FELONS OR CONVICTIONS OR REVOCATION OR INMATE OR INMATES OR HIGH-SECURITY)/DE FROM 144,34,434,7,99,65,35,6

90. (SUBSTANCE-ABUSE OR SUBSTANCE-MISUSE OR SUBSTANCE-USE)/DE FROM 144,34,434,7,99,65,35,6

91. (DRUG-DEPENDANCE OR DRUG-DEPENDENCY OR DRUG-ABUSE OR DRUG-MISUSE OR DRUG-ADDICT OR DRUG-ADDICTION)/DE FROM 144,34,434,7,99,65,35,6 
(Continued)

92. (CHEMICAL-DEPENDANCY OR OPIATE-DEPENDENCY OR HEROIN-DEPENDENCY OR CRACK-DEPENDENCY OR COCAINE-DEPENDENCY OR AMPHETAMINES OR ADDICTION OR DEPENDENCE-DISORDER OR DRUG-INVOLVED)/DE FROM 144,34,434,7,99,65,35,6

93. S40 OR S57:S85

94. S45 OR S86:S89

95. S55 OR S90:S92

96. S93 AND S94 AND S95

\section{Appendix 6. ASSIA search strategy}

\section{ASSIA search}

1. remand

2. prison or prisoner or prisoners

3. offender*

4. criminal*

5. probation

6. court or courts

7. tribunal or tribunals

8. secure establishment*

9. secure facilit*

10. reoffend*

11. reincarcerat*

12. recidivi*

13. ex-offender*

14. jail or jails

15. incarcerat* 


\section{(Continued)}

16. convict or convicts

\section{7. convicted}

18. felon or felons

19. conviction*

20. reconviction*

21. high security

22. law enforcement

23. Substance abuse* or substance misuse* or substance use*

24. drug dependanc* or drug abuse* or drug use*

25. drug misuse* or drug addict*

26. narcotics addict* narcotics use* narcotics misuse* narcotics abuse*

27. chemical dependanc*

28. opiates

29. heroin

30. crack

31. cocaine

32. amphetamines

33. cocaine

34. addiction

35. dependence disorder*

36. drug involved

37. Substance-related disorders

38. amphetamine-related disorders

39. cocaine-related disorders

40. marijuana abuse

Interventions for drug-using offenders with co-occurring mental illness (Review)

Copyright $\Subset 2015$ The Cochrane Collaboration. Published by John Wiley \& Sons, Ltd. 
(Continued)

41. opioid-related disorders

42. street drugs

43. designer drugs

44.1 or 2 or 3 or 4 or 5 or 6 or 7 or 8 or 9 or 10 or 11 or 12 or 13 or 14 or 15 or 16 or 17 or 18 or 19 or 20 or 21 or 22

45.23 or 24 or 25 or 26 or 27 or 28 or 29 or 30 or 31 or 32 or 33 or 34 or 35 or 36 or 37 or 38 or 39 or 40 or 41 or 42 or 43

46. 44 and 45

\section{Appendix 7. Sociological Abstracts search strategy}

\section{Sociological Abstracts}

1. remand in de

2. detention in de

3. prisoners in de

4. prisons in de

5. offenders in de

6. parole in de

7. probation in de

8. correctional system in de

9. courts in de

10. imprisonment in de

11. criminal justice in de

12. criminal proceedings in de

13. recidivism in de

14. jail in de 


\section{(Continued)}

15. institutionalization (persons) in de

16. conviction/convictions in de

17. (remand or prison* or offender* or criminal* or probation or court or courts or secure establishment*) in ti,ab

18. (reoffend* or reincarcerat* or recidivi* or ex-offend* or jail or jails or incarcerat* or secure facilit* or convict* or revocation or inmate*) in ti,ab

19. \#1 or \#2 or \#3 or \#4 or \#5 or \#6 or \#7 or \#8 or \#9 or \#10 or \#11 or \#12 or \#13 or \#14 or \#15 or \#16 or \#17 or \#18 or \#19

20. substance abuse in de

21. explode "Drug-Abuse" in DE

22. "Drug-Injection" in DE

23. explode "Narcotic-Drugs" in DE

24. "Cocaine-" in DE

25. "Addiction-" in DE

26. explode "Psychedelic-Drugs" in DE

27. (substance abuse* or substance misuse* or substance use*) in ti,ab

28. (drug abuse* or drug misuse* or drug use*) in ti,ab

29. (drug dependenc* or drug addict* or narcotics abuse* or narcotics use* or narcotics misuse* or narcotics addict*) in ti,ab

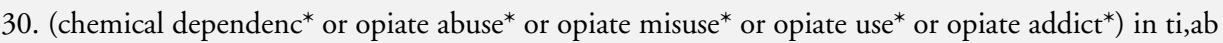

31. (heroin abuse* or heroin misuse* or heroin use* or heroin addict*) in ti,ab

32. (crack abuse* or crack misuse* or crack use* or crack addict*) in ti,ab

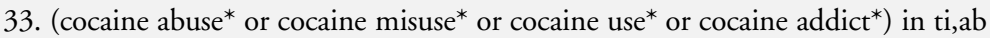

34. (amphetamine* abuse* $^{*}$ or amphetamine* misuse* or amphetamine* use* $^{*}$ or amphetamine* addict $^{*}$ ) in ti,ab

35. (dependence disorder or drug involved) in ti,ab

36. \#22 or \#23 or \#24 or \#25 or \#26 or \#27 or \#28 or \#29 or \#30 or \#31 or \#32 or \#33 or \#34 or \#35

37. $\# 19$ and \#36

38. "Detoxification-" in DE

Interventions for drug-using offenders with co-occurring mental illness (Review)

Copyright @ 2015 The Cochrane Collaboration. Published by John Wiley \& Sons, Ltd. 
(Continued)

39. "Methadone-Maintenance" in DE

40. "Counseling-" in DE

41. "Psychotherapy-" in DE

42. "Assertiveness-" in DE

43. (detoxification in de) or (methadone maintenance in de) or (treatment programs in de)

44. (counseling in de) or (psychotherapy in de) or (assertiveness in de) or (group therapy in de) or (goals in de) or (self control in de)

45. (interpersonal communication in de) or (social interaction in de) or (social competence in de) or (coping in de)

46. (social behavior in de) or (group work in de) or (lifestyle in de)

47. (after care in de) or (support networks in de) or (self help in de) or (self help groups in de) or (outreach programmes in de)

48. (outreach programs in de) or (referral in de) or (delinquency prevention in de) or (diversion/diversions in de)

49. (peer groups in de) or (peer influence in de) or (drug use screening in de) or (rehabilitation in de) or (work experience in de)

50. (detox* or methadone maintenance or methadone prescri* or antagonist prescri* or dimorphine or naltrexone) in ti,ab

51. (therapeutic communit* or motivational interview* or motivational enhance* or counseling or counselling or psychotherapy or cognitive behavi*) in ti,ab

52. (moral training or cognitive restructuring or assertiveness training or relaxation training) in ti,ab

53. (rational-emotive or rational emotive or family relationship therap* or community reinforcement or self monitoring or goal setting or self control training) in ti,ab

54. (self management or interpersonal skills or social skills or basic skills or relapse prevent* or prevent* relapse or craving reduc* or reduc* craving) in ti,ab

55. (trigger* or coping skills or anger management or group work or lifestyle modif* or high intensity training or resettlement or throughcare) in ti,ab

56. (aftercare or after care or brief solution or brief intervention* or 12 step* $^{*}$ or twelve step* or minnesota program* or needle exchange or nes) in ti,ab

57. (syringe exchange or dual diagnosis or narcotics anonymous or self help or selfhelp or outreach or bail support) in ti,ab

58. (arrest referral* or diversion or dtto or dttos or drug treatment or carat or carats or counseling assessment or combined orders) in ti,ab 


\section{(Continued)}

59. (drug-free or drug free or peer support or evaluation* or urinalysis or drug testing or drug use screen* or rehabilitation or discrete

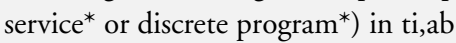

60. (residential program* or residential scheme* or residential service*) in ti,ab

61. (asro or addressing substance or pasro or prisons addressing or acupuncture or shock or boot camp*) in ti,ab

62. (work ethic or drug education or tasc or treatment accountability) in ti,ab

63. \#38 or \#39 \#or \#40 or \#41 or \#42 or \#43 or \#44 or \#45 or \#46 or \#47 or \#48 or \#49 or \#50 or \#51 or \#52 or \#53 or \#54 or \# 55 or \#56 or \#57 or \#58 or \#59 or \#60 or \#61 or \#62

64. \#37 and \#63

\section{Appendix 8. HMIC search strategy}

\section{HMIC}

1. remand in de

2. detention in de

3. prisoners in de

4. prisons in de

5. offenders in de

6. parole in de

7. probation in de

8. correctional system in de

9. courts in de

10. imprisonment in de

11. criminal justice in de

12. criminal proceedings in de

13. recidivism in de

14. jail in de

Interventions for drug-using offenders with co-occurring mental illness (Review)

Copyright $\Subset 2015$ The Cochrane Collaboration. Published by John Wiley \& Sons, Ltd. 


\section{(Continued)}

15. institutionalization (persons) in de

16. conviction/convictions in de

17. (remand or prison* or offender* or criminal* or probation or court or courts or secure establishment*) in ti,ab

18. (reoffend* or reincarcerat* or recidivi* or ex-offend* or jail or jails or incarcerat* or secure facilit* or convict* or revocation or inmate*) in ti,ab

19 . $\# 1$ or $\# 2$ or $\# 3$ or $\# 4$ or $\# 5$ or $\# 6$ or $\# 7$ or $\# 8$ or $\# 9$ or $\# 10$ or $\# 11$ or $\# 12$ or $\# 13$ or $\# 14$ or $\# 15$ or $\# 16$ or $\# 17$ or \#18

20. substance abuse in de

21. explode "Drug-Abuse" in DE

22. "Drug-Injection" in DE

23. explode "Narcotic-Drugs" in DE

24. "Cocaine-" in DE

25. "Addiction-" in DE

26. explode "Psychedelic-Drugs" in DE

27. (substance abuse* or substance misuse* or substance use*) in ti,ab

28. (drug abuse* or drug misuse* or drug use*) in ti,ab

29. (drug dependenc* or drug addict* or narcotics abuse* or narcotics use* or narcotics misuse* or narcotics addict*) in ti,ab

30. (chemical dependenc* or opiate abuse* or opiate misuse* or opiate use* or opiate addict*) in ti,ab

31. (heroin abuse* or heroin misuse* or heroin use* or heroin addict*) in ti,ab

32. (crack abuse* or crack misuse* or crack use* or crack addict*) in ti,ab

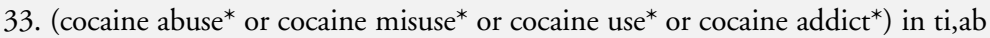

34. (amphetamine* abuse* $^{*}$ or amphetamine* misuse* $^{*}$ or amphetamine* use* $^{*}$ or amphetamine* addict $^{*}$ ) in ti,ab

35. (dependence disorder or drug involved) in ti,ab

36. \#20 or \#21 or \#22 or \#23 or \#24 or \#25 or \#26 or \#27 or \#28 or \#29 or \#30 or \#31 or \#32 or \#33 or \#34 or \#35

37. \#19 and \#36

Interventions for drug-using offenders with co-occurring mental illness (Review) 


\section{Appendix 9. PAIS search strategy}

\section{PAIS}

1. ((reoffend* or reincarcerat* $^{*}$ or recidivi* or ex-offend* or jail or jails or incarcerat* ${ }^{*}$ or secure facilit* ${ }^{*}$ or convict* or revocation or inmate* ${ }^{*}$ in ti,ab)

2. ((remand or prison* or offender* or criminal* or probation or court or courts or secure establishment*) in ti,ab)

3. ((drug dependenc* or drug addict* or narcotics abuse* or narcotics use* or narcotics misuse* or narcotics addict*) in ti,ab)

4. ((drug abuse* or drug misuse* or drug use* $\left.{ }^{*}\right)$ in ti,ab) or ((substance abuse* or substance misuse* or substance use*) in ti,ab)

5. ((detox* or methadone maintenance or methadone prescri* or antagonist prescri* or dimorphine or naltrexone) in ti,ab)

6. ((dependence disorder or drug involved) in ti,ab)

7. ((amphetamine* abuse* or amphetamine* misuse* or amphetamine* use* or amphetamine* addict*) in ti,ab)

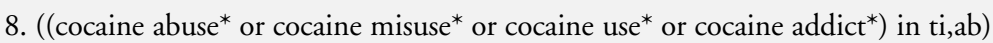

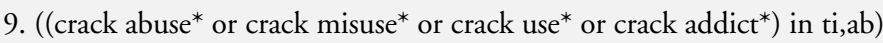

10. ((heroin abuse* or heroin misuse* or heroin use* or heroin addict*) in ti,ab)

11. ((chemical dependenc* or opiate abuse* or opiate misuse* or opiate use* or opiate addict*) in ti,ab)

12. ((moral training or cognitive restructuring or assertiveness training or relaxation training) in ti,ab)

13. ((therapeutic communit* or motivational interview* or motivational enhance* or counseling or counselling or psychotherapy or cognitive behavi*) in ti,ab)

14. ((work ethic or drug education or tasc or treatment accountability) in ti,ab)

15. ((asro or addressing substance or pasro or prisons addressing or acupuncture or shock or boot camp*) in ti,ab)

16. ((arrest referral* or diversion or dtto or dttos or drug treatment or carat or carats or counseling assessment or combined orders) in $\mathrm{ti}, \mathrm{ab})$

17. ((residential program* or residential scheme* or residential service* ${ }^{*}$ in ti,ab)

18. ((syringe exchange or dual diagnosis or narcotics anonymous or self help or selfhelp or outreach or bail support) in ti,ab)

19. ((drug-free or drug free or peer support or evaluation* or urinalysis or drug testing or drug use screen* or rehabilitation or discrete service* or discrete program*) in ti,ab)

20. ((aftercare or after care or brief solution or brief intervention* or 12 step* $^{*}$ or twelve step* or minnesota program* or needle exchange or nes) in ti,ab) 


\section{(Continued)}

21. ((trigger* or coping skills or anger management or group work or lifestyle modif* or high intensity training or resettlement or throughcare) in ti,ab)

22. ((self management or interpersonal skills or social skills or basic skills or relapse prevent* or prevent* relapse or craving reduc* or reduc* craving) in ti,ab)

24. ((rational-emotive or rational emotive or family relationship therap* or community reinforcement or self monitoring or goal setting or self control training) in ti,ab)

\section{5. \#1 or \#2}

26. \#3 or \#4 or \#5 or \#6 or \#7 or \#8 or 9 or \#10 or \#11

$27 . \# 12$ or $\# 13$ or $\# 14$ or $\# 15$ or $\# 16$ or $\# 17$ or \#18 or \#19 or \#20 or \#21 or \#22 or \#23 or \#24

28. 25 and \#26 and \#27

\section{Appendix 10. SIGLE search strategy}

\section{SIGLE}

1. ((reoffend ${ }^{*}$ or reincarcerat* ${ }^{*}$ recidivi* or ex-offend* ${ }^{*}$ or jail or jails or incarcerat* or secure facilit* or convict* or revocation or inmate*) in ti,ab)

2. ((remand or prison* or offender* or criminal* or probation or court or courts or secure establishment $\left.{ }^{*}\right)$ in ti,ab

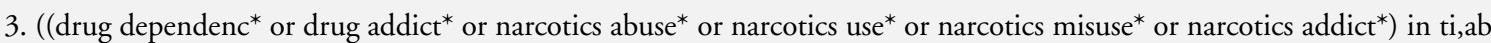

4. ((drug abuse* or drug misuse* or drug use* $)$ in ti,ab

5. ((substance abuse* or substance misuse* or substance use* ${ }^{*}$ in ti,ab

6. ((detox ${ }^{*}$ or methadone maintenance or methadone prescri* or antagonist prescri* or dimorphine or naltrexone) in ti,ab

7. ((dependence disorder or drug involved) in ti,ab

8. ((amphetamine* abuse* or amphetamine* misuse* or amphetamine* use* or amphetamine* addict*) in ti,ab

9. ((cocaine abuse* or cocaine misuse* or cocaine use* or cocaine addict*) in ti,ab

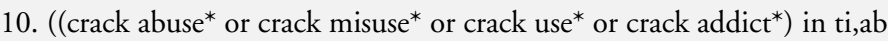

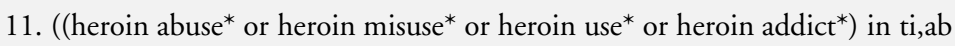


(Continued)

12. ((chemical dependenc* ${ }^{*}$ or opiate abuse* or opiate misuse* or opiate use* or opiate addict*) in ti,ab

13. \#1 or \#2

14. $\# 3$ or $\# 4$ or $\# 5$ or $\# 6$ or $\# 7$ or $\# 8$ or $\# 9$ or $\# 10$ or $\# 11$ or $\# 12$

15. \#13 and \#14

\section{Appendix I I. Criminal Justice Abstracts search strategy}

\section{CJA search}

1. (substance abuse* or substance misuse* or substance use or substance users) in ti,ab,de

2. substance related in ti,ab,de

3. drug related in ti,ab,de

4. (drug dependenc* or drug abuse* or drug misuse* or drug use or drug users or drug addiction) in ti,ab,de

5. (narcotics use or narcotics users or narcotics abuse* or narcotics misuse* or chemical dependenc*) in ti,ab,de

6. (opiates or heroin or crack or cocaine or amphetamines or addict or addicts or addicted or dependence disorder* or drug involved) in ti,ab,de

7. (designer drugs or street drugs or polydrug misuse* or polydrug abuse*) in ti,ab,de

8. \#1 or \#2 or \#3 or \#4 or \#5 or \#6 or \#7

9. ((antagonist near prescri*) or diamorphine or naltrexone) in ti,ab,de

10. (therapeutic communit* or (motivational near interview* $\left.{ }^{*}\right)$ in ti,ab,de

11. (motivational near enhancement) in ti,ab,de

12. (counselling or counseling) in ti,ab,de

13. (psychotherap* or cognitive behav* or behav* therap* or (moral near training)) in ti,ab,de

14. (cognitive restructuring or (assertiveness near train*) or relaxation training) in ti,ab,de

15. (rational emotive or family relationship therap*) in ti,ab,de

16. (community reinforcement or self monitoring or goal setting or goalsetting) in ti,ab,de 


\section{(Continued)}

17. (self control near training) in ti,ab, de

18. (self management) in ti,ab,de

19. (interpersonal skills near training) in ti,ab,de

20. ((social skills or basic skills) near training) in ti,ab,de

21. ((relapse near prevent $\left.t^{*}\right)$ or (craving near reduc* $)$ in ti,ab,de

22. (trigger* or coping skills or anger management or group work or (lifestyle near modif*)) in ti,ab,de

23. (high intensity training or resettlement or throughcare or aftercare or after care) in ti,ab,de

24. (brief solution* or brief intervention*) in ti,ab,de

25. (minnesota in ti,ab) in ti,ab,de

26. (12 step* or twelve step*) in ti,ab,de

27. (needle exchange or nes or syringe exchange) in ti,ab,de

28. (dual diagnosis or narcotics anonymous or self help or selfhelp or outreach) in ti,ab,de

29. (bail support or bail program* or arrest referral* or diversion or dtto* or drug treatment) in ti,ab,de

30. (carat or counselling assessment or counseling assessment) in ti,ab,de

31. (combined order* or drug free wing* or drug free environment* or peer support) in ti,ab,de

32. (user evaluations or urinalys* or urinanalys* or drug test* or rehab* or discrete service*) in ti,ab,de

33. (discrete program* or residential program* or residential scheme*) in ti,ab,de

34. (asro or addressing substance*) in ti,ab,de

35. (pasro or prisons addressing) in ti,ab,de

36. (acupuncture or shock or boot camp or boot camps or work ethic camp*) in ti,ab,de

37. (drug education or tasc or treatment accountability) in ti,ab,de

38. (detoxification or detox or methadone maintenance or (methadone near prescri*)) in ti,ab,de

$39 . \# 9$ or $\# 10$ or \#11 or \#12 or \#13 or \#14 or \#15 or \#16 or \#17 or \#18 or \#19 or \#20 or \#21 or \#22 or \#23 or \#24 or \#25 or \#26

or \#27 or \#28 or \#29

Interventions for drug-using offenders with co-occurring mental illness (Review) 
Appendix I2. National Research Register search strategy

\section{NRR search}

1. REMAND

2. PRISON*

\section{OFFENDER*}

4. ((CRIMINAL* or PROBATION) or COURT) or COURTS)

5. (SECURE next ESTABLISHMENT*)

6. REOFFEND*

7. REINCARCERAT*

8. RECIDIV*

\section{EXOFFEND*}

10. ((JAIL or JAILS) or INCARCERAT*)

11. (SECURE next FACILIT*)

12. (((CONVICT* or REVOCATION) or INMATE*) OR (HIGH next SECURITY))

\section{PRISONERS:ME}

14. LAW-ENFORCEMENT:ME

15. JURISPRUDENCE:ME

\section{CRIME:ME}

17. $\# 1$ or $\# 2$ or $\# 3$ or $\# 4$ or $\# 5$ or $\# 6$ or $\# 7$ or $\# 8$ or $\# 9$ or $\# 10$

18. \#11 or \#12 or \#13 or \#14 or \#15 or \#16 
(Continued)

19. \#17 or \#18

20. ((SUBSTANCE next ABUSE*) or (SUBSTANCE next MISUSE*)) OR (DRUG NEXT DEPENDENC*)) OR (DRUG NEXT ABUSE*)) OR (DRUG NEXT MISUSE*)) OR (DRUG NEXT USE*)) OR (DRUG NEXT ADDICTION))

21. ((NARCOTICS or (CHEMICAL next DEPENDENC*)) OR (OPIATE NEXT ADDICT*)) OR (OPIATE NEXT DEPENDENC*)) OR (OPIATE NEXT ABUSE*)) OR (OPIATE NEXT MISUSE*))

22. ((HEROIN next ADDICT*) or (HEROIN next DEPENDENC*)) OR (HEROIN NEXT MISUSE*)) OR (HEROIN NEXT ABUSE*))

23. ((CRACK next ADDICT*) or (CRACK next DEPENDENC*)) OR (CRACK NEXT MISUSE*)) OR (CRACK NEXT ABUSE*)) OR (CRACK NEXT USE*))

24. ((COCAINE next ADDICT*) or (COCAINE next DEPENDENC*)) OR (COCAINE NEXT MISUSE*)) OR (COCAINE NEXT ABUSE*)) OR (COCAINE NEXT USE*))

25. ((AMPHETAMINE* next ADDICT*) or (AMPHETAMINE* next DEPENDENC*)) OR (AMPHETAMINE* NEXT MISUSE*)) OR (AMPHETAMINE* NEXT ABUSE*)) OR (AMPHETAMINE* NEXT USE*))

26. ((ADDICTS or (DEPENDENCE next DISORDER)) OR (DRUG NEXT INVOLVED))

27. (SUBSTANCE-RELATED and DISORDERS:ME)

28. SUBSTANCE-RELATED-DISORDERS:ME

29. AMPHETAMINE-ABUSE:ME

30. COCAINE-ABUSE:ME

31. MARIJUANA-ABUSE:ME

32. OPIOID-RELATED-DISORDERS:ME

33. PHENCYCLIDINE-ABUSE:ME

34. SUBSTANCE-ABUSE-INTRAVENOUS:ME

35. SUBSTANCE-WITHDRAWAL-SYNDROME:ME

36. (STREET next DRUGS)

38. STREET-DRUGS:ME

39. DESIGNER-DRUGS:ME

40. NARCOTICS:ME

41. (COCAINE:ME or AMPHETAMINES:ME)

Interventions for drug-using offenders with co-occurring mental illness (Review)

Copyright @ 2015 The Cochrane Collaboration. Published by John Wiley \& Sons, Ltd. 


\section{PSYCHOTROPIC-DRUGS:ME}

45. $\# 20$ or $\# 21$ or $\# 22$ or $\# 23$ or $\# 24$ or $\# 25$ or $\# 26$ or $\# 27$ or $\# 28$ or $\# 29$ or $\# 30$ or $\# 31$ or $\# 32$ or $\# 33$ or $\# 34$ or $\# 35$ or $\# 36$ or $\# 37$ or \#38 or \#39 or \#40 or \#41 or \#42 or \#43 or \#44

46. 19 and 45

\section{Appendix 13. SPECTRA search strategy}

\section{SPECTRA search}

1. $\{$ remand $\}$ or $\{$ prison $\}$ or $\{$ offender $\}$ or $\{$ criminal $\}$ or $\{$ probation $\}$ or $\{$ court $\}$ or $\{$ tribunal $\}$ or $\{$ secure establishment $\}$ or $\{$ secure facilit $\}$ or $\{$ reoffend or $\{$ reincarcerat $\}$ or $\{$ recidivi $\}$ or $\{$ ex-offender $\}$ or $\{$ jail $\}$ or $\{$ incarcerat $\}$ or $\{$ convict $\}$ or $\{$ felon $\}$ or $\{$ reconvict $\}$ or $\{$ high security $\}$ or $\{$ law enforcement $\}$

$\{$ remand or $\{$ prison $\}$ or $\{$ offender $\}$ or $\{$ criminal $\}$ or $\{$ probation $\}$ or $\{$ court $\}$ or $\{$ tribunal $\}$ or $\{$ secure establishment $\}$ or $\{$ secure facilit $\}$ or $\{$ reoffend $\}$ or $\{$ reincarcerat $\}$ or $\{$ recidivi $\}$ or $\{$ ex-offender $\}$ or $\{$ jail $\}$ or $\{$ incarcerat $\}$ or $\{$ convict $\}$ or $\{$ felon $\}$ or $\{$ reconvict $\}$ or $\{$ high security $\}$ or $\{$ law enforcement $\}$

2. $\{$ substance $\}$ or $\{$ dependenc $\}$ or $\{$ drug abuse $\}$ or $\{$ drug use $\}$ or $\{$ drug misuse $\}$ or \{addict $\}$

All indexed fields: \{remand or $\{$ prison $\}$ or $\{$ offender $\}$ or $\{$ criminal $\}$ or $\{$ probation $\}$ or $\{$ court $\}$ or $\{$ tribunal $\}$ or $\{$ secure establishment $\}$ or $\{$ secure facilit $\}$ or $\{$ reoffend $\}$ or $\{$ reincarcerat $\}$ or $\{$ recidivi $\}$ or $\{$ ex-offender $\}$ or $\{$ jail $\}$ or $\{$ incarcerat $\}$ or $\{$ convict $\}$ or $\{$ felon $\}$ or $\{$ reconvict $\}$ or $\{$ high security\} or $\{$ law enforcement

OR

All unindexed fields: $\{$ remand $\}$ or $\{$ prison $\}$ or $\{$ offender $\}$ or $\{$ criminal $\}$ or $\{$ probation $\}$ or $\{$ court $\}$ or $\{$ tribunal $\}$ or $\{$ secure establishment $\}$ or $\{$ secure facilit\} or $\{$ reoffend $\}$ or $\{$ reincarcerat $\}$ or $\{$ recidivi $\}$ or $\{$ ex-offender $\}$ or $\{$ jail $\}$ or $\{$ incarcerat $\}$ or $\{$ convict $\}$ or $\{$ felon $\}$ or $\{$ reconvict $\}$ or $\{$ high security $\}$ or $\{$ law enforcement $\}$

AND

All unindexed fields: \{substance $\}$ or $\{$ dependenc $\}$ or $\{$ drug abuse $\}$ or $\{$ drug use $\}$ or $\{$ drug misuse $\}$ or $\{$ addict $\}$ or $\{$ narcotics $\}$ or $\{$ opiates\} or $\{$ heroin $\}$ or $\{$ crack $\}$ or $\{$ cocaine $\}$ or $\{$ amphetamines $\}$ or $\{$ drug involved $\}$ or $\{$ substance-related or $\{$ amphetamine-related or $\{$ cocainerelated or $\{$ marijuana $\}$ or $\{$ opioid $\}$ or $\{$ street drug $\}$ or $\{$ designer drug\}

3. narcotics

4. opiates

5. heroin

6. $\{$ crack $\}$

7. cocaine

8. amphetamines

Interventions for drug-using offenders with co-occurring mental illness (Review)

Copyright (๑) 2015 The Cochrane Collaboration. Published by John Wiley \& Sons, Ltd. 
(Continued)

9. drug involved

10. substance-related

11. amphetamine-related

12. cocaine-related

13. marijuana

14. opioid

15. street drug

16. designer drug

17. 2 or 3 or 4 or 5 or 6 or 7 or 8 or 9 or 10 or 11 or 12 or 13 or 14 or 15 or 16

18. 1 AND 17

Appendix 14. Criteria for assessing risk of bias

\begin{tabular}{|c|c|c|}
\hline Item & Judgement & Description \\
\hline \multirow[t]{3}{*}{$\begin{array}{l}\text { 1. Random sequence generation (selection } \\
\text { bias) }\end{array}$} & Low risk & $\begin{array}{l}\text { The investigators describe a random component in the sequence gener- } \\
\text { ation process such as: random number table; computer random num- } \\
\text { ber generator; coin tossing; shuffling cards or envelopes; throwing dice; } \\
\text { drawing of lots; minimisation }\end{array}$ \\
\hline & High risk & $\begin{array}{l}\text { The investigators describe a non-random component in the sequence } \\
\text { generation process such as: odd or even date of birth; date (or day) of } \\
\text { admission; hospital or clinic record number; alternation; judgement of } \\
\text { the clinician; results of a laboratory test or a series of tests; availability of } \\
\text { the intervention }\end{array}$ \\
\hline & Unclear risk & $\begin{array}{l}\text { Insufficient information about the sequence generation process to permit } \\
\text { judgement of low or high risk }\end{array}$ \\
\hline 2. Allocation concealment (selection bias) & Low risk & $\begin{array}{l}\text { Investigators enrolling participants could not foresee assignment because } \\
1 \text { of the following, or an equivalent method, was used to conceal alloca- } \\
\text { tion: central allocation (including telephone, web-based, and pharmacy- } \\
\text { controlled, randomisation); sequentially numbered drug containers of } \\
\text { identical appearance; sequentially numbered, opaque, sealed envelopes }\end{array}$ \\
\hline
\end{tabular}

Interventions for drug-using offenders with co-occurring mental illness (Review) 
High risk Investigators enrolling participants could possibly foresee assignments because 1 of the following methods was used: open random allocation schedule (e.g. a list of random numbers); assignment envelopes without appropriate safeguards (e.g. if envelopes were unsealed or nonopaque or not sequentially numbered); alternation or rotation; date of birth; case record number; any other explicitly unconcealed procedure

Unclear risk Insufficient information to permit judgement of low or high risk. This is usually the case if the method of concealment is not described or not described in sufficient detail to allow a definite judgement

3. Blinding of participants and providers Low risk (performance bias)

Objective outcomes
No blinding or incomplete blinding, but the review authors judge that the outcome is not likely to be influenced by lack of blinding; blinding of participants and key study personnel ensured, and unlikely that the blinding could have been broken
4. Blinding of participants and providers Low risk (performance bias)

Subjective outcomes
Blinding of participants and providers and unlikely that the blinding could have been broken

High risk

No blinding or incomplete blinding, and the outcome is likely to be influenced by lack of blinding

Blinding of key study participants and personnel attempted, but likely that the blinding could have been broken, and the outcome is likely to be influenced by lack of blinding

Unclear risk Insufficient information to permit judgement of low or high risk

5. Blinding of outcome assessor (detection Low risk bias)

Objective outcomes

6. Blinding of outcome assessor (detection Low risk bias)

Subjective outcomes
No blinding of outcome assessment, but the review authors judge that the outcome measurement is not likely to be influenced by lack of blinding Blinding of outcome assessment ensured, and unlikely that the blinding could have been broken

No blinding of outcome assessment, but the review authors judge that the outcome measurement is not likely to be influenced by lack of blinding Blinding of outcome assessment ensured, and unlikely that the blinding could have been broken

High risk No blinding of outcome assessment, and the outcome measurement is likely to be influenced by lack of blinding

Blinding of outcome assessment, but likely that the blinding could have been broken, and the outcome measurement is likely to be influenced by lack of blinding

Unclear risk Insufficient information to permit judgement of low or high risk 
7. Incomplete outcome data (attrition bias) Low risk For all outcomes except retention in treatment or drop-out
No missing outcome data

Reasons for missing outcome data unlikely to be related to true outcome (for survival data, censoring unlikely to be introducing bias)

Missing outcome data balanced in numbers across intervention groups, with similar reasons for missing data across groups

For dichotomous outcome data, the proportion of missing outcomes compared with observed event risk not enough to have a clinically relevant impact on the intervention effect estimate

For continuous outcome data, plausible effect size (difference in means or standardised difference in means) among missing outcomes not enough to have a clinically relevant impact on observed effect size

Missing data have been imputed using appropriate methods

All randomised participants are reported/analysed in the group they were allocated to by randomisation irrespective of non-compliance and cointerventions (intention to treat)

High risk Reason for missing outcome data likely to be related to true outcome, with either imbalance in numbers or reasons for missing data across intervention groups

For dichotomous outcome data, the proportion of missing outcomes compared with observed event risk enough to induce clinically relevant bias in intervention effect estimate

For continuous outcome data, plausible effect size (difference in means or standardised difference in means) among missing outcomes enough to induce clinically relevant bias in observed effect size

'As-treated' analysis done with substantial departure of the intervention received from that assigned at randomisation

Unclear risk Insufficient information to permit judgement of low or high risk (e.g. number randomised not stated, no reasons for missing data provided; number of drop-out not reported for each group)

8. Selective reporting (reporting bias) Low risk

The study protocol is available and all of the study's pre-specified (primary and secondary) outcomes that are of interest in the review have been reported in the pre-specified way

The study protocol is not available, but it is clear that the published reports include all expected outcomes, including those that were prespecified (convincing text of this nature may be uncommon)

High risk Not all of the study's pre-specified primary outcomes have been reported 1 or more primary outcomes is reported using measurements, analysis methods, or subsets of the data (e.g. subscales) that were not pre-specified 1 or more reported primary outcomes were not pre-specified (unless clear justification for their reporting is provided, such as an unexpected adverse effect)

1 or more outcomes of interest in the review are reported incompletely so that they cannot be entered in a meta-analysis

The study report fails to include results for a key outcome that would be expected to have been reported for such a study 


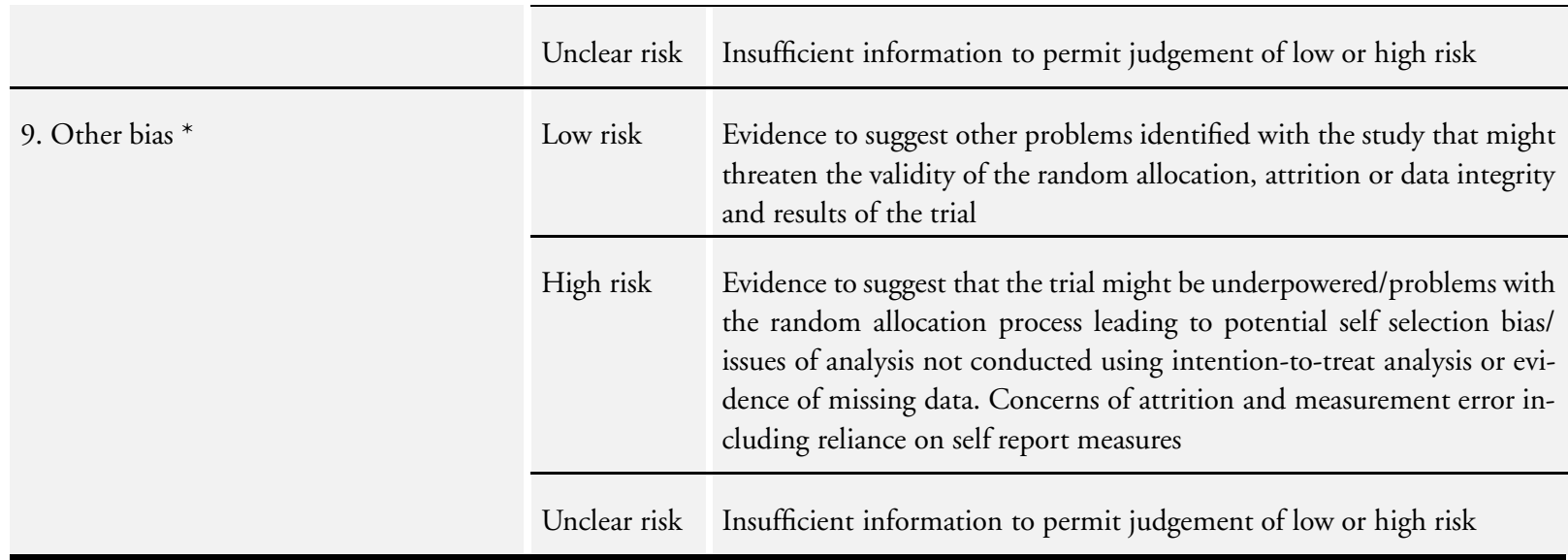

\section{WHAT'S NEW}

Last assessed as up-to-date: 31 May 2014.

\begin{tabular}{lll}
\hline Date & Event & Description \\
\hline 2 June 2015 & Amended & Amended byline \\
\hline 18 May 2015 & New citation required but conclusions have not changed & conclusions not changed \\
\hline 11 July 2014 & New search has been performed & $\begin{array}{l}\text { This review has been update to May 2014. The process } \\
\text { has added an additional 3 trials bringing the total number } \\
\text { of trials for this review to 8 represented by 14 publications }\end{array}$ \\
\hline
\end{tabular}

\section{H I S T O R Y}

Review first published: Issue 1, 2014

\begin{tabular}{|c|c|c|}
\hline Date & Event & Description \\
\hline 28 May 2012 & New search has been performed & $\begin{array}{l}\text { This review has been updated using searches to } 21 \text { st March } \\
2013 \text {. The review represents one in a family of four re- } \\
\text { views. The reviews cover pharmacological, non pharma- } \\
\text { cological and drug using female offenders. This review } \\
\text { of interventions with drug-using offenders with co-occur- } \\
\text { ring mental illness contains five randomised controlled } \\
\text { trials. The trials represent a total of } 1,502 \text { participants }\end{array}$ \\
\hline
\end{tabular}

Interventions for drug-using offenders with co-occurring mental illness (Review)

Copyright (๑) 2015 The Cochrane Collaboration. Published by John Wiley \& Sons, Ltd. 
2 October 2011 New search has been performed

8 June $2011 \quad$ New search has been performed

19 May 2006 New citation required and conclusions have changed Substantive amendment
The updated edit of this review produced a new document with additional findings with searches up to 11 th November 2011. Five new authors have been added to this version of the review. These include Steven Duffy, Rachael McCool, Matthew Neilson, Catherine Hewitt and Marrissa Martyn-St James

Converted to new review format.

Review has been substantially updated

\section{CONTRIBUTIONSOFAUTHORS}

One review author (DF) constructed and conducted the searches. Three review authors (AEP, MN, RW) independently inspected titles and abstracts identified by the search strategy. We obtained each potentially relevant study as a full article, and two review authors independently assessed these for inclusion In the case of discordance, a third review author arbitrated. Where it was not possible to evaluate the study because of language problems or missing information, we classified the study as 'translation/information required to determine decision' until we could obtain a translation or further details. Five review authors (AEP, MM-SJ, JMG, RW, MN) conducted data extraction for the papers, and one review author (CG) conducted data extraction and a narrative summary of the cost-effectiveness studies. Five review authors (MM-ST, MN, CH, RW, AEP) compiled and organised the results, and all eight review authors contributed to the final draft text.

\section{DECLARATIONSOF INTEREST}

Amanda E Perry have no interests to declare relating to this work

Matthew Neilson have no interests to declare relating to this work

Marrissa Martyn-St James have no interests to declare relating to this work

Julie M Glanville have no interests to declare relating to this work

Dave Fox have no interests to declare relating to this work

Rebecca Woodhouse have no interests to declare relating to this work

Catherine Hewitt have no interests to declare relating to this work

Interventions for drug-using offenders with co-occurring mental illness (Review) 


\section{SOURCES OF SUPPORT}

\section{Internal sources}

- Reviewer from Cochrane Drugs and Alcohol Group, Other.

A reviewer from the Drugs and Alcohol Group provided the researchers with the results of a search strategy for three databases

\section{External sources}

- The Department of Health funded the original review, UK.

\section{DIFFERENCES BETWEEN PROTOCOLANDREVIEW}

None.

\section{NDEX TERMS}

\section{Medical Subject Headings (MeSH)}

Case Management; Crime [prevention \& control; statistics \& numerical data]; Diagnosis, Dual (Psychiatry); Law Enforcement; Mental Disorders [*therapy]; Motivational Interviewing; Randomized Controlled Trials as Topic; Substance-Related Disorders [*therapy]; Therapeutic Community

\section{MeSH check words}

Adolescent; Adult; Female; Humans; Male; Young Adult 